\title{
A Species List and Bibliography of the Insects Recorded from Norfolk Island
}

C.N. Smithers

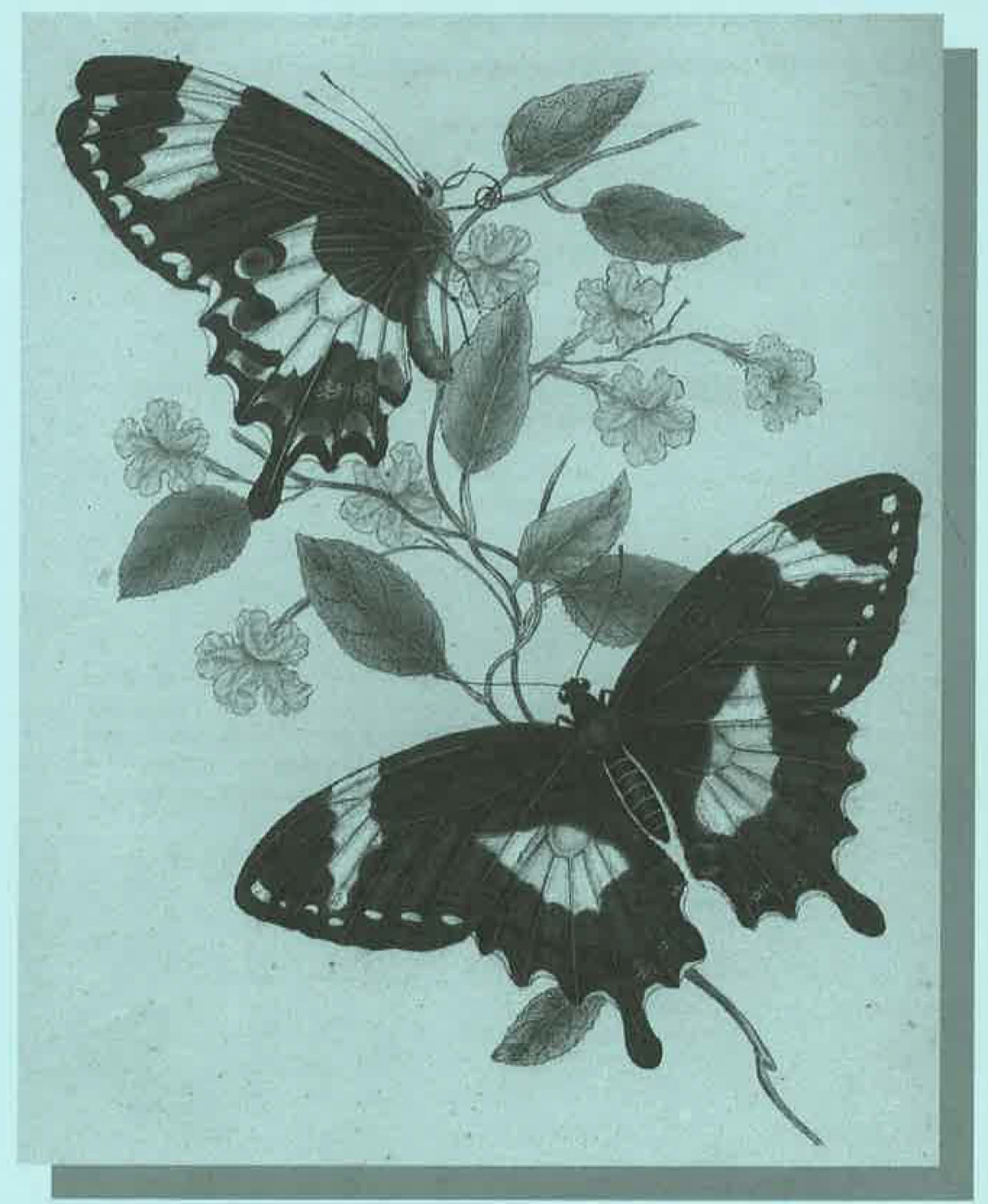

Technical Reports of the Australian Museum 


\section{TECHNICAL REPORTS OF THE AUSTRALIAN MUSEUM}

\section{Editorial Committee:}

\section{Chair: J.M. Leis (Vertebrate Zoology)}

V.J. Attenbrow (ANTHROPOLOGY)

D.J. Bickel (InVERTEBRATE ZOOLOGY)

G.D. Edgecombe (Palaeontology)

A.E. Greer (Vertebrate Zoology)

F.L. Sutherland (GEOLOGY)

G.D.F. Wilson (INVERTEBRATE ZOOLOGY)

Editor: S.F. McEvey

shanem@amsg.austmus.gov.au

Director: D.J.G. Griffin

(C) Copyright Australian Museum, 1998

No part of this publication may be reproduced without permission of the Editor.

\section{November 1998}

$\$ 20.00$ retail

$\$ 21.50$ retail plus postage within Australia or New Zealand $\$ 24.50$ retail plus economy air postage internationally

Printed by RodenPrint Pty Ltd, Sydney

ISSN 1031-8062

ISBN 0-7313-9500-X
The Australian Museum's mission is to increase understanding of, and influence public debate on, the natural environment, human societies and human interaction with the environment. The Museum has maintained the highest standards of scholarship in these fields for more than 100 years, and is one of Australia's foremost publishers of original research in anthropology, geology and zoology.

The Records of the Australian Museum (ISSN 00671975) publishes the results of research that has utilised Australian Museum collections and studies that relate in other ways to the Museum's mission. There is an emphasis on research in the Australasian, southwest Pacific or Indian Ocean regions. The Records is released as three issues of one volume annually, volume 50 is published this year. Monographs are published about once a year as Records of the Australian Museum, Supplements. Supplement 24 (ISBN 0-7313-8807-0) was published in June 1998. Catalogues, lists and databases have, since 1988, been published as numbered Technical Reports of the Australian Museum (ISSN 1031-8062). Technical Report number 13 was published in 1998. Australian Museum Memoirs (ISSN 0067-1967) ceased in 1983.

These three publications-Records, Supplements and Technical Reports-are distributed to libraries at more than 700 academic institutions throughout the world. Librarians are invited to propose exchange agreements with the Australian Museum Research Library (http://www. austmus.gov.au/is/lib.htm). Back issues are available for purchase direct from the Australian Museum Scientific Publications office. Subscriptions are accepted only for the Records.

Authors are invited to submit manuscripts presenting results of their original research. Manuscripts meeting the aforementioned subject requirements and the stylistic requirements outlined in the Instructions to Authors are assessed by external referees.

www.austmus.gov.au 


\title{
A Species List and Bibliography of the Insects Recorded from Norfolk Island
}

\author{
C.N. SMITHERS \\ Entomology Department, Australian Museum, 6 College Street, Sydney NSW 2000, Australia
}

\begin{abstract}
Nearly 700 species of insects are listed as having been recorded from Norfolk Island and a bibliography of more than 200 papers is provided from which the records have been obtained. This paper is intended to be a working document which, it is hoped, will make it largely unnecessary for subsequent workers to repeat time-consuming literature searches.
\end{abstract}

SMITHERS, C.N., 1998. A species list and bibliography of the insects recorded from Norfolk Island. Technical Reports of the Australian Museum 13: 1-55.

Some thirty years ago residents of Norfolk Island expressed concern for the future of the fauna and flora of the island. As a result of this the Survival Commission of the International Union for Conservation of Nature and Natural Resources asked the Australian Conservation Foundation to make an urgent investigation into the situation. In response to this Professor John Turner, Dr Ruurd Hoogland and I visited the island in late 1967. The report which resulted was published as the Australian Conservation Foundation Special Publication Number 1 (Turner, Smithers \& Hoogland, 1968). This report made strong recommendations on the preservation and conservation of the natural, historical and scenic values of Norfolk and nearby Nepean and Philip islands at a time when environmental concerns were not generally as great as they are now. Much has been achieved since that early report, with establishment of the then recommended Norfolk Island National Park and Botanical Garden being central factors in the protection of the natural environment and maintenance of the natural biodiversity on the island (Anon., 1984). Since the Australian Museum's initial involvement many members of the museum staff have visited the island, some several times, with the result that the association established in 1967 continued. In recent years a number of other institutions and individuals have also become more interested in the fauna of Norfolk Island.

An appendix to the initial report (Turner et al., 1968) included an incomplete list of the island's insects, which was virtually a list of those species thought at the time to be endemic to Norfolk. As a result of subsequent work by many authors it is now possible to provide a more authoritative and comprehensive species list and bibliography of the relevant literature. It is hoped that these will largely overcome the need for others to repeat the timeconsuming task of seeking out the scattered literature. As this document is intended to be a working tool the following comments on its compilation are provided to help users understand its coverage and its limitations.

It began as a literature search, made in preparation for the visit to Norfolk Island in late 1967, which used as a starting point a paper by Hawkins (1943). This dealt with a collection made by Mrs Ida McComish which had been obtained by the British Museum and with material already in that museum. Hawkins also included previously 
published records with the result that the paper was effectively a preliminary list of species known from Norfolk Island. As pointed out by Hawkins, the material could not be dealt with fully owing to wartime conditions in Britain. Many species were identified to genus only, sometimes with uncertainty, and listed as such. The paper, produced under very difficult circumstances, indicated that fewer than 250 species had been recorded from the island. Continued personal interest in the island's natural history prompted me to maintain and expand the species list and bibliography as time and opportunity arose. The result is this present list of nearly 700 species supported by a bibliography of more than 200 publications.

The systematic arrangement of orders and families used here is largely that in CSIRO (ed., 1991). Below subfamily level or, where subfamilies are not indicated, below family level, the genera and species are arranged alphabetically.

The entry for each species is headed by what appears to be the currently valid name in bold type. Following this are references to its occurrence on Norfolk Island. Records have been checked in the original publications wherever possible. In many instances the original name and reference to the species do not appear. This is because the species was originally described from somewhere other than Norfolk and subsequently recorded from there, as indicated by the references. The list should not, therefore, be taken as a guide to nomenclatural changes in general because references to name changes not associated with mention of Norfolk Island may not be included. These can, however, usually be traced through the references which are listed. In the species list I have used the convention of inserting an exclamation mark (!) to indicate a misidentification as distinct from a synonym.

Authors who have studied Norfolk material after Hawkins (1943) have not always indicated whether the species or material to which they refer is the same as or includes that tentatively identified by him. In cases where there is uncertainty about this I have included Hawkins' record as a separate entry.

Records in Common \& Waterhouse (1982), the "field version" of the standard text on Australian butterflies, are not listed individually under the species but the work is listed in the bibliography.

Dr Jeremy Holloway provided notes on species of butterflies and moths which were later to appear on an issue of Norfolk Island postage stamps. The insects included some undescribed forms. His notes were used as publicity material in the Norfolk Island Philatelic Bulletin (Holloway, 1976a,b, 1977b) some of which apparently predate later, more formal, publications. It appears that the timing and manner in which the descriptive material, illustrations and names were presented constitute acceptable availability of some of the names under the International Code of Zoological Nomenclature. I have attempted to list the species involved in appropriately formal manner where the names seem to be valid. For those interested in the identification of more recently collected material there are more detailed descriptions of the same forms in other publications (e.g., Holloway, 1977a) which can be used for that purpose.

Some of the records of Phthiraptera from Norfolk Island given by Palma \& Barker (1996) are not currently supported by specimens. They were listed for Norfolk because known, wide ranging, vertebrate hosts have been recorded from there and hence it can be assumed that their parasites also occur there (Palma \& Barker, 1996, p. 84).

Several works refer to distribution of insect species in general terms such as "widespread in the Pacific". It cannot be assumed from such statements that the species actually occurs on Norfolk Island and such references are not included in the list unless they have a definite statement of occurrence on Norfolk.

The present list indicates the state of published knowledge of the insects of Norfolk and which groups appear to be reasonably well worked and which probably require more collecting and investigation. It should be remembered that there are already collections of some groups awaiting study.

Users of the list will be able to make their own assessments of the state of knowledge for each group. There is, however, one group, the Lepidoptera, which deserves special mention. This group is now very well known because of the remarkably energetic, persistent and regular collecting efforts of Mrs Maurge Jowett and the study of her material by Dr Jeremy Holloway. Their work stands out as a fine example of what can be achieved by paying continuous and systematic attention to a circumscribed area.

It is inevitable that a compilation covering a wide range of groups, which this list and bibliography is, will contain errors and omissions but I hope these will be minimal and that they do not detract too much from the usefulness of the work. Omissions are most likely to occur where single species have been mentioned in publications not dealing specifically with Norfolk Island and such records are also the most likely to be absent from abstracting journals. I have attempted, and I hope achieved, reasonable coverage of references coming to my notice up to 30 September, 1996.

I would be grateful if authors could provide me with reprints of future papers which include mention of Norfolk Island species and I would be pleased to hear of omissions from and errors in this list so that the list can be kept up to date. 


\section{LIST OF INSECT SPECIES RECORDED FROM NORFOLK ISLAND}

\section{COLLEMBOLA}

ARTHROPLEONA

PODUROIDEA

\section{NEANURIDAE}

NEANURINAE

Australonura norfolkensis Greenslade \& Deharvheng Australonura norfolkensis Greenslade \& Deharvheng, 1990. Invertebrate Taxonomy 3(5): 580, fig. 7.

Australonura norfolkensis Greenslade \& Deharvheng. Greenslade,1994.Zoological Catalogue of Australia 22: 31.

Australonura sp.

Australonura sp. Greenslade \& Deharvheng, 1990. Invertebrate Taxonomy 3(5): 581.

\section{FRIESEINAE}

Friesea claviseta Axelson

Friesea claviseta Axelson. Greenslade, 1994. Zoological Catalogue of Australia 22: 33.

\section{HYPOGASTRURIDAE}

Ceratophysella communis (Folsom)

Ceratophysella communis (Folsom). Greenslade, 1994. Zoological Catalogue of Australia 22: 49.

Xenylla australiensis de Gama

Xenylla australiensis de Gama. Greenslade, 1994. Zoological Catalogue of Australia 22: 53.

Xenylla grisea Axelson

Xenylla grisea Axelson. Greenslade, 1994. Zoological Catalogue of Australia 22: 54.

Xenylla welchi Folsom

Xenylla welchi Folsom. Greenslade, 1994. Zoological Catalogue of Australia 22: 57.

\section{SYMPHYPLEONA}

\section{SMINTHURIDAE}

Katianna zebra (Womersley)

Katianna zebra (Womersley). Greenslade, 1994. Zoological Catalogue of Australia 22: 126.

\section{THYSANURA}

\section{NICOLETIIDAE}

\section{NICOLETIINAE}

Trinemura norfolkensis Smith

Trinemura norfolkensis Smith, 1988. Journal of the Australian entomological Society 27(1): 52, figs. 14-27.

\section{ODONATA}

\section{ZYGOPTERA}

COENAGRIONOIDEA

\section{COENAGRIONIDAE}

\section{AGRIOCNEMIDINAE}

Agriocnemis exsudans Selys-Longchamps

Agriocnemis exsudans Selys-Longchamps. Kimmins, 1941. Entomologist's monthly Magazine 77: 135.

Agriocnemis vitiensis Tillyard. Kimmins, 1941. Entomologist's monthly Magazine 77: 135.

Agriocnemis exsudans Selys-Longchamps. Hawkins, 1943. Annals and Magazine of Natural History, London (11)9(60): 899.

Agriocnemis vitiensis Tillyard. Hawkins, 1943. Annals and Magazine of Natural History, London (11)9(60): 899.

Agriocnemis exsudans Selys-Longchamps. Holloway, 1977a. Lepidoptera of Norfolk Island, p. 267.

Agriocnemis exsudans Selys-Longchamps. Wise, 1980. Records of the Auckland Institute and Museum 17: 176.

Agriocnemis exsudans Selys-Longchamps. Winstanley \& Brock, 1983. New Zealand Entomologist 7(4): 456.

\section{ISCHNURINAE}

Ischnura aurora (Brauer)

Ischnura aurora (Brauer). Tillyard, 1917. Proceedings of the Linnean Society of New South Wales 42: 531, 532.

Ischnura aurora (Brauer). Schmidt, 1938. Annals of the entomological Society of America 31(3): 324.

Ischnura aurora (Brauer). Kimmins, 1941. Entomologist's monthly Magazine 77: 135.

Ischnura aurora (Brauer). Hawkins, 1943. Annals and Magazine of Natural History, London (11)9(60): 899.

Ischnura aurora (Brauer). Holloway, 1977a. Lepidoptera of Norfolk Island, p. 267.

Ischnura aurora (Brauer). Winstanley \& Brock, 1983. New Zealand Entomologist 7(4): 456.

Ischnura aurora aurora (Brauer). Houston \& Watson, 1988. Zoological Catalogue of Australia 6: 48.

\section{ANISOPTERA}

\section{AESHNOIDEA}

\section{AESHNIDAE}

\section{AESHNINAE}

Aeshna brevistyla (Rambur)

Aeshna brevistyla (Rambur). Smithers, 1976. Australian entomological Magazine 3(3): 57.

Aeshna brevistyla (Rambur). Holloway, 1977a. Lepidoptera of Norfolk Island, p. 267.

Aeshna brevistyla (Rambur). Wise, 1980. Records of the Auckland Institute and Museum 17: 176.

Aeshna brevistyla (Rambur). Winstanley \& Brock, 1983. New Zealand Entomologist 7(4): 456, figs. 1A-1C. 


\section{LIBELLULOIDEA}

\section{CORDULIIDAE}

\section{CORDULIINAE}

Hemicordulia australiae (Rambur)

Hemicordulia australiae (Rambur). Tillyard, 1917. Proceedings of the Linnean Society of New South Wales 42: 530, 531.

Hemicordulia australiae (Rambur). Kimmins, 1941. Entomologist's monthly Magazine 77: 135.

Hemicordulia australiae (Rambur). Hawkins, 1943. Annals and Magazine of Natural History, London (11)9(60): 899.

Hemicordulia australiae (Rambur). Holloway, 1977a. Lepidoptera of Norfolk Island, p. 267.

Hemicordulia australiae (Rambur). Wise, 1980. Records of the Auckland Institute and Museum 17: 176.

Hemicordulia australiae (Rambur). Winstanley \& Brock, 1983. New Zealand Entomologist 7(4): 456.

Hemicordulia australiae (Rambur). Winstanley, 1983. New Zealand Entomologist 7(4): 458.

Hemicordulia australiae (Rambur). Houston \& Watson, 1988. Zoological Catalogue of Australia 6: 108.

Hemicordulia australiae (Rambur). Watson, Theischinger \& Abbey, 1991. The Australian Dragonflies, p. 218.

\section{BLATTODEA}

\section{BLATTOIDEA}

\section{BLATTIDAE}

\section{BLATTINAE}

Blatta sp.

Blatta sp. Olliff, 1888a. Proceedings of the Linnean Society of New South Wales (2)2(4): 1014.

Periplaneta americana (Linnaeus)

Periplaneta americana (Linnaeus). Holloway, 1977a. Lepidoptera of Norfolk Island, p. 268.

Periplaneta americana (Linnaeus). Rentz, 1988. Invertebrate Taxonomy 2: 1024, 1074.

\section{POLYZOSTERIINAE}

Methana marginalus (Saussure)

Methana marginalus (Saussure). Holloway, 1977a. Lepidoptera of Norfolk Island, p. 268.

Methana marginalus (Saussure). Rentz, 1988. Invertebrate Taxonomy 2: 1024, 1074.

Platyzosteria (Melanozosteria) sp.

Platyzosteria (Melanozosteria) sp. Rentz, 1988. Invertebrate Taxonomy 2: 1024, 1074.

\section{BLABEROIDEA}

\section{BLATTELLIDAE}

\section{BLATTELLINAE}

Blattella germanica (Linnaeus)

Blattella germanica (Linnaeus). Holloway, 1977a. Lepidoptera of Norfolk Island, p. 268.

Blattella germanica (Linnaeus). Rentz, 1988. Invertebrate Taxonomy 2: 1024, 1076.

\section{PSEUDOMOPINAE}

Carbrunneria sp.

Carbrunneria sp. Rentz, 1988. Invertebrate Taxonomy 2: 1076.

Ectoneura sp.

Ectoneura sp. Rentz, 1988. Invertebrate Taxonomy 2: 1076.

\section{BLABERIDAE}

\section{PANESTHIINAE}

Panesthia cribrata Saussure

Panesthia cribrata Saussure. Roth, 1977. Australian Journal of Zoology, Supplementary Series 48: 14, figs. 5-11.

Panesthia cribrata Saussure. Holloway, 1977a. Lepidoptera of Norfolk Island, p. 268.

Panesthia cribrata Saussure. Rentz, 1988. Invertebrate Taxonomy 2: 1024, 1073.

\section{PYCNOSCELINAE}

Pycnoscelis indicus (Fabricius)

Pycnoscelis indicus (Fabricius). Rentz, 1988. Invertebrate Taxonomy 2: 1024, 1074.

\section{ISOPTERA}

\section{KALOTERMITIDAE}

Glyptotermes brevicornis Froggatt

Glyptotermes brevicornis Froggatt, 1896. Proceedings of the Linnean Society of New South Wales 21(4): 547; pl. 36, figs. $6,6 \mathrm{a}$.

?Calotermes (Glyptotermes) claripennis Hill. Hill, 1926. Proceedings of the Royal Society of Victoria 38(N.S.): 196.

Calotermes (Glyptotermes) brevicornis (Froggatt). Hill, 1942. Termites (Isoptera) of the Australian Region p. 86 , figs. 38,39 .

Glyptotermes brevicornis Froggatt. Holloway, 1977a. Lepidoptera of Norfolk Island, p. 268.

Glyptotermes brevicornis Froggatt. Watson, 1989. Termites (Isoptera) on Lord Howe Island, p. 6.

\section{DERMAPTERA}

\section{FORFICULINA}

\section{ANISOLABIDOIDEA}

\section{ANISOLABIDIDAE}

\section{ANISOLABIDINAE}

Anisolabis xenia Kirby

Anisolabis xenia Kirby, 1890. Journal of the Linnean Society of London 23: 517.

Anisolabis xenia Kirby. Sakai, 1970. Dermapterorum Catalogus Praeliminaris. I: 58.

Anisolabis xenia Kirby. Holloway, 1977a. Lepidoptera of Norfolk Island, p. 268. 


\section{ORTHOPTERA}

\section{ENSIFERA}

\section{TETTIGONIOIDEA}

\section{TETTIGONIIDAE}

\section{CONOCEPHALINAE}

Austrosalomona personafrons Rentz

Austrosalomona personafrons Rentz, 1988. Invertebrate Taxonomy 2: 1035, figs. 26-32, 34, 36, 38-40, 42, 47, 98.

\section{Conocephalus sp.}

Conocephalus sp. Holloway, 1977a. Lepidoptera of Norfolk Island, p. 268.

Conocephalus upoluensis (Karny)

Conocephalus upoluensis (Karny). Pitkin, 1980. Bulletin of the British Museum of Natural History (Entomology) 41(5): 318, 342, figs. 12, 30, 41.

Conocephalus upoluensis (Karny). Rentz, 1988. Invertebrate Taxonomy 2: 1020, 1031, figs. 22, 25, 43.

Euconocephalus sp.

Euconocephalus sp. Holloway, 1977a. Lepidoptera of Norfolk Island, p. 268.

Pseudorhynchus lessonii Serville

Pseudorhynchus lessonii Serville. Rentz, 1988. Invertebrate Taxonomy 2: 1020, 1032, figs. 23-25.

\section{LISTROSCELIDINAE}

Phisis tardipes Rentz

Phisis tardipes Rentz, 1988. Invertebrate Taxonomy 2: 1020, 1027, figs. 12-21, 87.

\section{PHANEROPTERINAE}

Caedicia araucariae Rentz

Caedicia araucariae Rentz, 1988. Invertebrate Taxonomy 2: 1020, 1048, figs. 44, 48, 56, 57, 66, 69, 70, 72, 73, 100.

Caedicia gracilis Rentz

Caedicia gracilis Rentz, 1988. Invertebrate Taxonomy 2: 1020, 1045, figs. 45, 49-55, 60, 61, 65, 69-71, 101.

Caedicia noctivaga Rentz

Caedicia noctivaga Rentz, 1988. Invertebrate Taxonomy 2: 1020, 1054, figs. 46, 63, 67, 74-76, 80, 82, 99.

Phaneroptera sp.

Phaneroptera sp. Olliff, 1888a. Proceedings of the Linnean Society of New South Wales (2)2(4): 1014.

\section{GRYLLOIDEA}

\section{GRYLLIDAE}

\section{GRYLLINAE}

Acheta ?australis Linnaeus

Acheta ?australis Linnaeus. Olliff, 1888a. Proceedings of the Linnean Society of New South Wales (2)2(4): 1014.

Lepidogryllus comparatus (Walker)

Lepidogryllus comparatus (Walker). Otte \& Rentz, 1985. Proceedings of the Academy of Natural Sciences of Philadelphia 13: 98.
Lepidogryllus comparatus (Walker). Rentz, 1988. Invertebrate Taxonomy 2: 1021, 1061, fig. 96.

Lepidogryllus parvulus (Walker)

Lepidogryllus parvulus (Walker). Rentz, 1988. Invertebrate Taxonomy 2: 1061.

Modicogryllus lepidus (Walker)

Modicogryllus lepidus (Walker). Wise, 1969. Records of the Auckland Institute and Museum 6(4-6): 423, fig. 1.

Teleogryllus commodus (Walker)

Gryllulus commodus (Walker). Chopard, 1951. Records of the South Australian Museum 9: 410, figs. 20, 21.

Teleogryllus commodus (Walker). Holloway, 1977a. Lepidoptera of Norfolk Island, p. 268.

Teleogryllus commodus (Walker). Otte \& Rentz, 1985. Proceedings of the Academy of Natural Sciences of Philadelphia 13: 98.

Teleogryllus commodus (Walker). Rentz, 1988. Invertebrate Taxonomy 2: 1021, fig. 85 .

Teleogryllus oceanicus (Le Guillou)

Teleogryllus oceanicus (Le Guillou). Otte \& Rentz, 1985. Proceedings of the Academy of Natural Sciences of Philadelphia 13: 98.

Teleogryllus oceanicus (Le Guillou). Rentz, 1988, Invertebrate Taxonomy 2: 1021, 1062, figs. 84, 97.

\section{NEMOBIINAE}

Dictyonemobius lateralis Chopard

Dictyonemobius lateralis Chopard. Holloway, 1977a. Lepidoptera of Norfolk Island, p. 268.

Dictyonemobius lateralis Chopard. Otte \& Rentz, 1985. Proceedings of the Academy of Natural Sciences of Philadelphia 13: 95, figs. 11, 12A, 12B, 13A, 13B, 14A, 14B.

Dictyonemobius lateralis Chopard. Rentz, 1988. Invertebrate Taxonomy 2: 1021, 1064, fig. 94.

Dictyonemobius pacificus Otte \& Rentz

Dictyonemobius pacificus Otte \& Rentz, 1985. Proceedings of the Academy of Natural Sciences of Philadelphia 13: 96 , figs. 13D, $14 \mathrm{C}$.

Dictyonemobius pacificus Otte \& Rentz. Rentz, 1988. Invertebrate Taxonomy 2: 1021, 1064, fig. 95.

\section{TRIGONIDIINAE}

Metioche vittaticollis (Stål)

Metioche vittaticollis (Stål). Otte \& Rentz, 1985. Proceedings of the Academy of Natural Sciences of Philadelphia 13: 97.

!Trigonidomorpha sjöstedti Chopard. Otte \& Rentz, 1985. Proceedings of the Academy of Natural Sciences of Philadelphia 13: 97. (cf. Rentz, 1988. Invertebrate Taxonomy 2: 1070).

Metioche vittaticollis (Stål). Rentz, 1988. Invertebrate Taxonomy 2: 1021, 1071.

\section{PHALANGOPSINAE}

Nesitathra philipensis Otte \& Rentz

Nesitathra philipensis Otte \& Rentz, 1985. Proceedings of the Academy of Natural Sciences of Philadelphia 13: 100 , figs. $16,17 \mathrm{~A}$.

Nesitathra philipensis Otte \& Rentz. Rentz, 1988. Invertebrate Taxonomy 2: 1021, 1072, figs. 93, 104. 


\section{MOGOPLISTINAE}

Ornebius howensis Chopard

Ornebius howensis Chopard. Otte \& Rentz, 1985. Proceedings of the Academy of Natural Sciences of Philadelphia 13: 99, fig. 15.

Ornebius howensis Chopard. Rentz, 1988. Invertebrate Taxonomy 2: 1021, 1071.

\section{ENEOPTERINAE}

\section{Adenopterus norfolkensis Chopard}

Adenopterus norfolkensis Chopard, 1951. Records of the South Australian Museum 9: 511, figs. 16, 87-89.

Adenopterus norfolkensis Chopard. Turner, Smithers \& Hoogland, 1968. The Conservation of Norfolk Island, p. 40. Adenopterus norfolkensis Chopard. Holloway, 1977a. Lepidoptera of Norfolk Island, p. 268.

Adenopterus norfolkensis Chopard. Otte \& Rentz, 1985. Proceedings of the Academy of Natural Sciences of Philadelphia 13: 93, figs. 9, 10.

Adenopterus norfolkensis Chopard. Rentz, 1988. Invertebrate Taxonomy 2: 1021, 1070, figs. 90, 105.

Insulascirtus christiani Otte \& Rentz

Insulascirtus christiani Otte \& Rentz, 1985. Proceedings of the Academy of Natural Sciences of Philadelphia 13: 90 , figs. $4 \mathrm{~A}, 5 \mathrm{~B}$.

Insulascirtus christiani Otte \& Rentz. Rentz, 1988. Invertebrate Taxonomy 2: 1021, 1067, figs. 91, 103.

Insulascirtus nythos Otte \& Rentz

Insulascirtus nythos Otte \& Rentz, 1985. Proceedings of the Academy of Natural Sciences of Philadelphia 13: 90, figs. 4B, 5A, 7C, 8 .

Insulascirtus nythos Otte \& Rentz. Rentz, 1988. Invertebrate Taxonomy 2: 1021, 1065, figs. 89, 92, 102.

\section{CAELIFERA}

\section{ACRIDOIDEA}

\section{ACRIDIDAE}

\section{ACRIDINAE}

Aiolopus thalassinus Willemse

Aiolopus thalassinus dubius Willemse. Hollis, 1968. Bulletin of the British Museum of Natural History (Entomology) 22(7): 351, figs. 24, 84, 97-102.

Aiolopus thalassinus dubius Willemse. Holloway, 1977a. Lepidoptera of Norfolk Island, p. 268.

Aiolopus thalassinus dubius Willemse. Rentz, 1988. Invertebrate Taxonomy 2: 1020, 1026.

Locusta migratoria (Linnaeus)

Locusta migratoria (Linnaeus). Rentz, 1988. Invertebrate Taxonomy 2: 1020, 1025.

Locusta sp.

Locusta sp. Olliff, 1888a. Proceedings of the Linnean Society of New South Wales (2)2(4): 1014.

\section{PSOCOPTERA}

\section{TROGIOMORPHA}

\section{ATROPETAE}

\section{LEPIDOPSOCIDAE}

\section{LEPOLEPIDINAE}

Lepolepis graemei Smithers \& Thornton

Lepolepis graemei Smithers \& Thornton, 1974. Records of the Australian Museum 29: 216, figs. 18-22.

Lepolepis graemei Smithers \& Thornton. Smithers, 1981. Australian entomological Magazine 7(6): 87.

Lepolepis graemei Smithers \& Thornton. Smithers, 1986. Australian entomological Magazine 13(1): 34.

Lepolepis graemei Smithers \& Thornton. Smithers, 1996. Zoological Catalogue of Australia 26: 9.

\section{ECHINOPSOCINAE}

Pteroxanium evansi Smithers \& Thornton

Pteroxanium evansi Smithers \& Thornton, 1974. Records of the Australian Museum 29: 213, figs. 6-11.

Pteroxanium evansi Smithers \& Thornton. Smithers, 1981. Australian entomological Magazine 7(6): 86.

Pteroxanium evansi Smithers \& Thornton. Smithers, 1986. Australian entomological Magazine 13(1): 34.

Pteroxanium evansi Smithers \& Thornton. Smithers, 1996. Zoological Catalogue of Australia 26: 10.

Pteroxanium insularum Smithers \& Thornton

Pteroxanium insularum Smithers \& Thornton, 1974. Records of the Australian Museum 29: 214, figs. 12-17.

Pteroxanium insularum Smithers \& Thornton. Smithers, 1981. Australian entomological Magazine 7(6): 86.

Pteroxanium insularum Smithers \& Thornton. Smithers, 1986. Australian entomological Magazine 13(1): 34.

Pteroxanium insularum Smithers \& Thornton. Smithers, 1996. Zoological Catalogue of Australia 26: 10.

Pteroxanium ralstonae Smithers \& Thornton

Pteroxanium ralstonae Smithers \& Thornton, 1974. Records of the Australian Museum 29: 210, figs. 1-5.

Pteroxanium ralstonae Smithers \& Thornton. Smithers, 1981. Australian entomological Magazine 7(6): 86.

Pteroxanium ralstonae Smithers \& Thornton. Smithers, 1986. Australian entomological Magazine 13(1): 34

Pteroxanium ralstonae Smithers \& Thornton. Smithers, 1996. Zoological Catalogue of Australia 26: 10.

\section{TROGIIDAE}

\section{TROGIINAE}

Cerobasis guestfalica (Kolbe)

Cerobasis guestfalica (Kolbe). Smithers, 1986. Australian entomological Magazine 13(1): 33.

Cerobasis guestfalica (Kolbe). Smithers, 1996. Zoological Catalogue of Australia 26: 12.

Lepinotus patruelis Pearman

Lepinotus patruelis Pearman. Smithers, 1986. Australian entomological Magazine 13(1): 33.

Lepinotus patruelis Pearman. Smithers, 1996. Zoological Catalogue of Australia 26: 14. 
Lepinotus sp.

Lepinotus sp. Hawkins, 1943. Annals and Magazine of Natural History, London (11)9(60): 899.

Trogium evansorum Smithers

Trogium evansorum Smithers, 1994. Australian Entomologist 21(4): 153 , figs. $1-10$.

\section{PSOCOMORPHA}

\section{CAECILIOIDEA}

\section{CAECILIIDAE}

\section{CAECILIINAE}

Caecilius insulatus Smithers \& Thornton

Caecilius insulatus Smithers \& Thornton, 1974. Records of the Australian Museum 29: 217, figs. 23-27.

Caecilius insulatus Smithers \& Thornton. Smithers, 1981. Australian entomological Magazine 7(6): 87.

Caecilius insulatus Smithers \& Thornton. Smithers, 1986. Australian entomological Magazine 13(1): 34.

Caecilius insulatus Smithers \& Thornton. Smithers, 1996. Zoological Catalogue of Australia 26: 33.

Caecilius pacificus Smithers \& Thornton

Caecilius pacificus Smithers \& Thornton, 1974. Records of the Australian Museum 29: 220, figs. 28-32.

Caecilius pacificus Smithers \& Thornton. Smithers, 1981. Australian entomological Magazine 7(6): 87.

Caecilius pacificus Smithers \& Thornton. Smithers, 1986. Australian entomological Magazine 13(1): 34.

Caecilius pacificus Smithers \& Thornton. Smithers, 1996. Zoological Catalogue of Australia 26: 33.

Caecilius sp.

Caecilius sp. Hawkins, 1943. Annals and Magazine of Natural History, London (11)9(60): 899.

\section{HOMILOPSOCIDEA}

\section{ECTOPSOCIDAE}

Ectopsocus briggsi McLachlan

Ectopsocus briggsi McLachlan. Smithers \& Thornton, 1974. Records of the Australian Museum 29: 221.

Ectopsocus briggsi McLachlan. Smithers, 1981. Australian entomological Magazine 7(6): 87.

Ectopsocus briggsi McLachlan. Smithers, 1986. Australian entomological Magazine 13(1): 34.

Ectopsocus briggsi McLachlan. Smithers, 1996. Zoological Catalogue of Australia 26: 42.

Ectopsocus inornatus Smithers \& Thornton

Ectopsocus inornatus Smithers \& Thornton, 1974. Records of the Australian Museum 29: 224, figs. 38-42.

Ectopsocus inornatus Smithers \& Thornton. Smithers, 1981. Australian entomological Magazine 7(6): 87.

Ectopsocus inornatus Smithers \& Thornton. Smithers, 1986. Australian entomological Magazine 13(1): 34

Ectopsocus inornatus Smithers \& Thornton. Smithers, 1996. Zoological Catalogue of Australia 26: 44.

Ectopsocus insularis Smithers \& Thornton

Ectopsocus insularis Smithers \& Thornton, 1974. Records of the Australian Museum 29: 221, figs. 33-37.

Ectopsocus insularis Smithers \& Thornton. Smithers, 1981. Australian entomological Magazine 7(6): 87.
Ectopsocus insularis Smithers \& Thornton. Smithers, 1986. Australian entomological Magazine 13(1): 34.

Ectopsocus insularis Smithers \& Thornton. Smithers, 1996. Zoological Catalogue of Australia 26: 44.

Ectopsocus richardsi (Pearman)

Ectopsocus richardsi (Pearman). Smithers, 1980. General and applied Entomology 12: 13, figs. 1-5.

Ectopsocus richardsi (Pearman). Smithers, 1981. Australian entomological Magazine 7(6): 87.

Ectopsocus richardsi (Pearman). Smithers, 1986. Australian entomological Magazine 13(1): 34.

Ectopsocus richardsi (Pearman). Smithers, 1996. Zoological Catalogue of Australia 26: 45.

\section{PERIPSOCIDAE}

Peripsocus milleri (Tillyard)

Peripsocus milleri (Tillyard). Smithers \& Thornton, 1974. Records of the Australian Museum 29: 225.

Peripsocus milleri (Tillyard). Smithers, 1981. Australian entomological Magazine 7(6): 87.

Peripsocus milleri (Tillyard). Smithers, 1986. Australian entomological Magazine 13(1): 34.

Peripsocus milleri (Tillyard). Smithers, 1996. Zoological Catalogue of Australia 26: 47.

Peripsocus norfolkensis Smithers \& Thornton

Peripsocus norfolkensis Smithers \& Thornton, 1974. Records of the Australian Museum 29: 225, figs. 43-46.

Peripsocus norfolkensis Smithers \& Thornton. Smithers, 1981. Australian entomological Magazine 7(6): 87.

Peripsocus norfolkensis Smithers \& Thornton. Smithers, 1986. Australian entomological Magazine 13(1): 34.

Peripsocus norfolkensis Smithers \& Thornton. Smithers, 1996. Zoological Catalogue of Australia 26: 48.

Peripsocus sp.

Peripsocus sp. Hawkins, 1943. Annals and Magazine of Natural History, London (11)9(60): 899.

\section{PSEUDOCAECILIIDAE}

\section{PSEUDOCAECILIINAE}

Heterocaecilius variabilis Smithers \& Thornton

Heterocaecilius variabilis Smithers \& Thornton, 1974. Records of the Australian Museum 29: 225, figs. 47-53.

Heterocaecilius variabilis Smithers \& Thornton. Smithers, 1981. Australian entomological Magazine 7(6): 87.

Heterocaecilius variabilis Smithers \& Thornton. Smithers, 1986. Australian entomological Magazine 13(1): 34.

Heterocaecilius variabilis Smithers \& Thornton. Smithers, 1996. Zoological Catalogue of Australia 26: 56.

\section{ELIPSOCIDAE}

\section{PROPSOCINAE}

Propsocus pulchripennis (Perkins)

Propsocus pulchripennis (Perkins). Smithers, 1986. Australian entomological Magazine 13(1): 33.

Propsocus pulchripennis (Perkins). Smithers, 1996. Zoological Catalogue of Australia 26: 65. 


\section{PHILOTARSIDAE}

\section{PHILOTARSINAE}

Haplophallus emmus Smithers \& Thornton

Haplophallus emmus Smithers \& Thornton, 1974. Records of the Australian Museum 29: 230, figs. 54-67.

Haplophallus emmus Smithers \& Thornton. Smithers, 1981. Australian entomological Magazine 7(6): 87.

Haplophallus emmus Smithers \& Thornton. Thornton, 1981. Systematic Entomology 6: 423.

Haplophallus emmus Smithers \& Thornton. Smithers, 1986. Australian entomological Magazine 13(1): 34.

Haplophallus emmus Smithers \& Thornton. Smithers, 1996. Zoological Catalogue of Australia 26: 60.

\section{PSOCETAE}

\section{PSOCIDAE}

\section{AMPHIGERONTIINAE}

Blaste lignicola (Enderlein)

Blaste lignicola (Enderlein). Smithers \& Thornton, 1974. Records of the Australian Museum 29: 234.

Blaste lignicola (Enderlein). Smithers, 1981. Australian entomological Magazine 7(6): 87.

Blaste lignicola (Enderlein). Smithers, 1986. Australian entomological Magazine 13(1): 34.

Blaste lignicola (Enderlein). Smithers, 1996. Zoological Catalogue of Australia 26: 69.

\section{MYOPSOCIDAE}

Myopsocus australis (Brauer)

Phlotodes australis (Brauer). Smithers \& Thornton, 1974. Records of the Australian Museum 29: 234 (in footnote).

Phlotodes australis (Brauer). Smithers, 1981. Australian entomological Magazine 7(6): 87.

Myopsocus australis (Brauer). Smithers, 1986. Australian entomological Magazine 13(1): 34.

Myopsocus australis (Brauer). Smithers, 1996. Zoological Catalogue of Australia 26: 78.

\section{PHTHIRAPTERA}

\section{AMBLYCERA}

\section{LAEMOBOTHRIIDAE}

Laemobothrion (Laemobothrion) tinnunculi (Linnaeus)

Laemobothrion (Laemobothrion) tinnunculi (Linnaeus). Palma \& Barker, 1996. Zoological Catalogue of Australia 26: 107.

\section{MENOPONIDAE}

Actornithophilus ceruleus (Timmerman)

Actornithophilus ceruleus (Timmerman). Nelson, 1969. Australian Zoologist 15(2): 199.

Actornithophilus ceruleus (Timmerman). Palma \& Barker, 1996. Zoological Catalogue of Australia 26: 110.

Actornithophilus incisus (Piaget)

Actornithophilus incisus (Piaget). Palma \& Barker, 1996. Zoological Catalogue of Australia 26: 111.
Actornithophilus ochraceus (Nitzsch)

Actornithophilus ochraceus (Nitzsch). Palma \& Barker, 1996. Zoological Catalogue of Australia 26: 111.

Austromenopon atrofulvum (Piaget)

Austromenopon atrofulvum (Piaget). Palma \& Barker, 1996. Zoological Catalogue of Australia 26: 115.

Austromenopon beckii (Kellogg)

Austromenopon beckii (Kellogg). Palma \& Barker, 1996. Zoological Catalogue of Australia 26: 115.

Colpocephalum subzerafae Tendeiro

Colpocephalum subzerafae subzerafae Tendeiro. Palma \& Barker, 1996. Zoological Catalogue of Australia 26: 122.

Eidmanniella albescens (Piaget)

Eidmanniella albescens (Piaget). Palma \& Barker, 1996. Zoological Catalogue of Australia 26: 124.

Kurodaia cryptostigmatia (Nitzsch)

Kurodaia cryptostigmatia (Nitzsch). Palma \& Barker, 1996. Zoological Catalogue of Australia 26: 131.

Longimenopus sp.

Longimenopus sp. Nelson, 1969. Australian Zoologist 15(2): 199

Myrsidea rustica (Giebel)

Myrsidea rustica (Giebel). Palma \& Barker, 1996. Zoological Catalogue of Australia 26: 138.

Pseudomenopon scopulacorne (Denny)

Pseudomenopon scopulacorne (Denny). Palma \& Barker, 1996. Zoological Catalogue of Australia 26: 142.

\section{RICINIDAE}

Ricinus mugimaki (Uchida)

Ricinus mugimaki (Uchida). Palma \& Barker, 1996. Zoological Catalogue of Australia 26: 146.

\section{ISCHNOCERA}

\section{PHILOPTERIDAE}

Alcedoecus sp.

Alcedoecus sp. Nelson, 1969. Australian Zoologist 15(2): 199.

Brueelia tenuis (Burmeister)

Brueelia tenuis (Burmeister). Palma \& Barker, 1996. Zoological Catalogue of Australia 26: 146.

Coloceras hemiphagae (Tendeiro)

Nitzschiella hemiphagae Tendeiro, 1972a. Rev. Cienc. Vet. (Lourenco Marques) (ser. A) 5: 2.

Coloceras hemiphagae (Tendeiro). Palma \& Barker, 1996. Zoological Catalogue of Australia 26: 166.

Coloceras restinctum (Tendeiro)

Patellinirmus restinctus Tendeiro, 1972b. Rev. Cienc. Vet. (Lourenco Marques) (ser. A) 5: 81.

Coloceras restinctum (Tendeiro). Palma \& Barker, 1996. Zoological Catalogue of Australia 26: 167.

Cuculicola kui Kettle

Cuculicola kui Kettle. Palma \& Barker, 1996. Zoological Catalogue of Australia 26: 171.

Degeeriella rufa (Burmeister)

Degeeriella rufa rufa (Burmeister). Palma \& Barker, 1996. Zoological Catalogue of Australia 26: 174. 
Halipeurus (Halipeurus) mirabilis Thompson Halipeurus (Halipeurus) mirabilis Thompson. Palma \& Barker, 1996. Zoological Catalogue of Australia 26: 185.

Halipeurus (Halipeurus) placodus Edwards Halipeurus (Halipeurus) placodus Edwards. Palma \& Barker, 1996. Zoological Catalogue of Australia 26: 186.

Pectinopygus annulatus (Piaget)

Pectinopygus annulatus (Piaget). Palma \& Barker, 1996. Zoological Catalogue of Australia 26: 198.

Philopterus excisus Nitzsch

Philopterus excisus microsomaticus Tandan. Palma \& Barker, 1996. Zoological Catalogue of Australia 26: 204.

Philopterus turdi (Denny)

Philopterus turdi (Denny). Nelson, 1969. Australian Zoologist 15(2): 199.

Philopterus turdi (Denny). Palma \& Barker, 1996. Zoological Catalogue of Australia 26: 204.

Quadraceps birostris (Giebel)

Quadraceps birostris (Giebel). Nelson, 1969. Australian Zoologist 15(2): 199.

Quadraceps birostris (Giebel). Palma \& Barker, 1996. Zoological Catalogue of Australia 26: 210.

Quadraceps charadrii (Linnaeus)

Quadraceps charadrii charadrii (Linnaeus). Palma \& Barker, 1996. Zoological Catalogue of Australia 26: 210.

Quadraceps hopkinsi Timmerman

Quadraceps hopkinsi Timmerman. Nelson, 1969. Australian Zoologist 15(2): 199.

Quadraceps hopkinsi apophoretus Timmerman. Palma \& Barker, 1996. Zoological Catalogue of Australia 26: 212.

Quadraceps separatus (Kellogg and Kuwana)

Quadraceps separatus (Kellogg and Kuwana). Palma \& Barker, 1996. Zoological Catalogue of Australia 26: 215.

Saemundssonia puellula Timmerman

Saemundssonia (Puffinoecus) puellula Timmerman. Palma \& Barker, 1996. Zoological Catalogue of Australia 26: 227.

Saemundssonia (Saemundssonia) conica (Denny)

Saemundssonia (Saemundssonia) conica conica (Denny). Palma \& Barker, 1996. Zoological Catalogue of Australia 26: 220.

Saemundssonia (Saemundssonia) lobaticeps (Giebel)

Saemundssonia (Saemundssonia) lobaticeps remota Timmerman. Palma \& Barker, 1996. Zoological Catalogue of Australia 26: 221.

Saemundssonia sp.

Saemundssonia sp.Nelson, 1969. AustralianZoologist15(2): 199.

Sturnidoecus sturni (Schrank)

Sturnidoecus sturni (Schrank). Nelson, 1969. Australian Zoologist 15(2): 199.

Sturnidoecus sturni (Schrank). Palma \& Barker, 1996. Zoological Catalogue of Australia 26: 228.

Trabeculus hexakon (Waterston)

Trabeculus hexacon [sic] (Waterston). Nelson, 1969. Australian Zoologist 15(2): 199.

Trabeculus hexakon (Waterston). Palma \& Barker, 1996. Zoological Catalogue of Australia 26: 229.

Trabeculus mirabilis (Kellogg)

Trabeculus mirabilis (Kellogg). Palma \& Barker, 1996. Zoological Catalogue of Australia 26: 229.

\section{HEMIPTERA}

\section{STERNORRHYNCHA}

\section{APHIDOIDEA}

\section{APHIDIDAE}

\section{APHIDINAE}

Aphis gossypii Glover

Aphis gossypii Glover. Hawkins, 1943. Annals and Magazine of Natural History, London (11)9(60): 897.

\section{COCCOIDEA}

\section{MARGARODIDAE}

Icerya purchasi Maskell

Icerya purchasi Maskell. Hawkins, 1943. Annals and Magazine of Natural History, London (11)9(60): 897.

\section{PSEUDOCOCCIDAE}

Pseudococcus sp.

Pseudococcus sp. Hawkins, 1943. Annals and Magazine of Natural History, London (11)9(60): 897.

\section{COCCIDAE}

Ceroplastes destructor Newstead

Ceroplastes destructor Newstead. Ben-Dov, 1993. A systematic catalogue of the soft scale insects of the world p. 31 .

Ceroplastes rubens del Guercio

Ceroplastes rubens del Guercio. Ben-Dov, 1993. A systematic catalogue of the soft scale insects of the world p. 49.

Ceroplastes sinensis Maskell

Ceroplastes sinensis Maskell. Ben-Dov, 1993. A systematic catalogue of the soft scale insects of the world p. 54 .

Coccus hesperidum Linnaeus

Coccus hesperidum Linnaeus. Hawkins, 1943. Annals and Magazine of Natural History, London (11)9(60): 897.

Coccus hesperidum Linnaeus. Ben-Dov, 1993. A systematic catalogue of the soft scale insects of the world p. 75 .

Eucalymnatus tessellatus (Signoret)

Eucalymnatustessellatus(Signoret).Ben-Dov,1993. A systematic catalogue of the soft scale insects of the world p. 129.

Saissetia coffeae (Walker)

Saissetia coffeae (Walker). Hawkins, 1943. Annals and Magazine of Natural History, London (11)9(60): 897.

Saissetia coffeae (Walker). Ben-Dov, 1993. A systematic catalogue of the soft scale insects of the world p. 305 .

Saissetia oleae (Oliver)

Saissetia oleae (Oliver). Ben-Dov, 1993. A systematic catalogue of the soft scale insects of the world p. 305 . 


\section{AUCHENORRHYNCHA}

\section{CICADOIDEA}

\section{CICADIDAE}

\section{TIBICININAE}

\section{Kikihia convicta (Distant)}

Cicada sp. Olliff, 1888a. Proceedings of the Linnean Society of New South Wales (2)2(4): 1014.

Melampsalta convicta Distant, 1892. Annals and Magazine of Natural History, London (6)9: 322.

Melampsalta convicta Distant. Goding \& Froggatt, 1904. Proceedings of the Linnean Society of New South Wales 29: 654.

Melampsalta convicta Distant. Distant, 1906. A synonymic Catalogue of the Homoptera. Part 1. Cicadidae p. 174.

Melampsalta convicta Distant. Hawkins, 1943. Annals and Magazine of Natural History, London (11)9(60): 897.

Cicadetta convicta (Distant). Metcalf, 1963. General Catalogue of the Homoptera Fasc. VIII(2): 306.

Kikihia convicta (Distant). Dugdale, 1972. New Zealand Journal of Science 14(4): 875.

Kikihia convicta (Distant). Fleming, 1973. New Zealand Journal of Science 16(2): 316.

Kikihia convicta (Distant). Holloway, 1977a. Lepidoptera of Norfolk Island, p. 269.

Kikihia convicta (Distant). Duffels \& van der Laan, 1985. Catalogueof theCidadoidea (Homoptera, Auchenorrhyncha) 1956-1980 p. 303. (Distribution given as New Zealand, but this is an error. M. Moulds, pers. comm.).

Kikihia convicta (Distant). Moulds, 1990. Australian Cicadas. P. 170; pl. 19, fig. 2.

Kikihia convicta (Distant). Anonymous, 1996. Norfolk Nature Notes 12(2): 4

\section{CICADELLOIDEA}

\section{CICADELLIDAE}

\section{IASSINAE}

Batracomorphus angustatus (Osborn)

Batracomorphus angustatus (Osborn). Knight, 1976. New Zealand Journal of Zoology 3: 91.

Batracomorphus angustatus (Osborn). Holloway, 1977a. Lepidoptera of Norfolk Island, p. 269.

\section{DELTOCEPHALINAE}

Deltocephalus samuelsoni Knight

Deltocephalus samuelsoni Knight, 1976. New Zealand Journal of Zoology 3: 96, figs. 4a-4c.

Deltocephalus samuelsoni Knight. Holloway, 1977a. Lepidoptera of Norfolk Island, p. 269.

Exitianus plebeius (Kirkaldy)

Exitianus plebeius (Kirkaldy). Knight, 1976. New Zealand Journal of Zoology 3: 92, fig. 1.

Exitianus plebeius (Kirkaldy). Holloway, 1977a. Lepidoptera of Norfolk Island, p. 269.

Nesoclutha pallida (Evans)

Nesoclutha pallida (Evans). Knight, 1976. New Zealand Journal of Zoology 3: 97.

Nesoclutha pallida (Evans). Holloway, 1977a. Lepidoptera of Norfolk Island, p. 269.
Orosius argentatus (Evans)

Orosius sp. (near albicinctus Distant). Hawkins, 1943. Annals and Magazine of Natural History, London (11)9(60): 869.

Orosius argentatus (Evans). Ghauri, 1966. Bulletin of the British Museum of Natural History (Entomology) 18: 242, figs. 6-8.

Orosius argentatus (Evans). Knight, 1976. New Zealand Journal of Zoology 3: 92, fig.2.

Orosius argentatus (Evans). Holloway, 1977a. Lepidoptera of Norfolk Island, p. 269.

\section{TYPHLOCYBINAE}

Zygina jowettae Knight

Zygina jowettae Knight, 1976. New Zealand Journal of Zoology 3: 90, figs. 4d-4h.

Zygina jowettae Knight. Holloway, 1977a. Lepidoptera of Norfolk Island, p. 269.

\section{FULGOROIDEA}

\section{DELPHACIDAE}

\section{DELPHACINAE}

Delphacodes sp.

Delphacodes sp. Hawkins, 1943. Annals and Magazine of Natural History, London (11)9(60): 896.

\section{CIXIIDAE}

Koroama sp.

Koroama sp. Holloway, 1977a. Lepidoptera of Norfolk Island, p. 269.

\section{ISSIDAE}

Hysteropterum truncatellum (Walker)

Hysteropterum truncatellum (Walker). Holloway, 1977a. Lepidoptera of Norfolk Island, p. 269.

\section{FLATIDAE}

Siphanta acuta Walker

Siphanta acuta Walker. Holloway, 1977a. Lepidoptera of Norfolk Island, p. 269.

\section{RICANIIDAE}

Scolypopa sp.

Scolypopa sp. (near australis Walker). Hawkins. 1943. Annals and Magazine of Natural History, London (11)9(60): 896.

Scolypopa sp. Holloway, 1977a. Lepidoptera of Norfolk Island, p. 269.

\section{HETEROPTERA}

\section{HYDROMETROIDEA}

\section{HYDROMETRIDAE}

\section{HYDROMETRINAE}

Hydrometra risbeci Hungerford

Hydrometra risbeci Hungerford. Cassis \& Gross, 1995. Zoological Catalogue of Australia 27.3A: 119. 


\section{GERROIDEA}

\section{VELIIDAE}

\section{MICROVELIINAE}

Microvelia oceanica Distant

Microvelia sp. (near oceanica Distant). Hawkins. 1943. Annals and Magazine of Natural History, London (11)9(60): 896.

Microvelia sp. (near oceanica Distant). Holloway, 1977a. Lepidoptera of Norfolk Island, p. 270.

Microvelia sp. Holloway, 1977a. Lepidoptera of Norfolk Island, p. 270.

Microvelia oceanica Distant. Cassis \& Gross, 1995. Zoological Catalogue of Australia 27.3A: 446.

\section{CIMICOIDEA}

\section{ANTHOCORIDAE}

\section{ANTHOCORINAE}

Buchananiella whitei Reuter

Buchananiella whitei Reuter. Holloway, 1977a. Lepidoptera of Norfolk Island, p. 269.

\section{NABIDAE}

\section{NABINAE}

Nabis (Tropiconabis) kinbergii Reuter

Nabis (Tropiconabis) kinbergii Reuter. Cassis \& Gross, 1995. Zoological Catalogue of Australia 27.3A: 220.

\section{MIROIDEA}

\section{MIRIDAE}

\section{PHYLINAE}

\section{Campylomma sp.}

Campylomma sp. Hawkins, 1943. Annals and Magazine of Natural History, London (11)9(60): 896.

Campylomma sp. Holloway, 1977a. Lepidoptera of Norfolk Island, p. 269.

\section{MIRINAE}

Chaetedus plumalis Eyles

Chaetedus plumalis Eyles. Holloway, 1977a. Lepidoptera of Norfolk Island, p. 269.

Chaetedus plumalis Eyles. Cassis \& Gross, 1995. Zoological Catalogue of Australia 27.3A: 179.

Taylorilygus nebulosus (Poppius)

Lygus sp. Hawkins, 1943. Annals and Magazine of Natural History, London (11)9(60): 896.

Taylorilygus sp. Holloway, 1977a. Lepidoptera of Norfolk Island, p. 269.

Taylorilygus nebulosus (Poppius). Cassis \& Gross, 1995. Zoological Catalogue of Australia 27.3A: 178.

Trigonotylus tenuis Reuter

Trigonotylus tenuis Reuter. Cassis \& Gross, 1995. Zoological Catalogue of Australia 27.3A: 182.

\section{ORTHOTYLINAE}

Coridromius variegatus Montrouzier

Coridromius variegatus Montrouzier. Holloway, 1977a. Lepidoptera of Norfolk Island, p. 269.

Coridromius variegatus Montrouzier. Cassis \& Gross, 1995. Zoological Catalogue of Australia 27.3A: 186.

Note: The following genus is not recorded from Norfolk Island by Cassis \& Gross (1995). The record is probably based on a misidentification (Cassis, pers. comm.).

Araspus sp.

Araspus sp. Holloway, 1977a. Lepidoptera of Norfolk Island, p. 269.

\section{TINGOIDEA}

\section{TINGIDAE}

TINGINAE

Leptobyrsa decora Drake

Leptobyrsa decora Drake. Holloway, 1977a. Lepidoptera of Norfolk Island, p. 269.

Teleonemia scrupulosa Stål

Teleonemia lantanae Distant. Hawkins, 1943. Annals and Magazine of Natural History, London (11)9(60): 897.

Teleonemia scrupulosa Stål. Holloway, 1977a. Lepidoptera of Norfolk Island, p. 270.

\section{REDUVIOIDEA}

\section{REDUVIIDAE}

\section{EMESINAE}

Empicoris rubromaculatus Blackburn

Empicoris (Ploiariola) rubromaculata Blackburn. Hawkins, 1943. Annals and Magazine of Natural History, London (11)9(60): 895.

Empicoris rubromaculata Blackburn. Holloway, 1977a. Lepidoptera of Norfolk Island, p. 270.

Leaylia norfolkiana (Wygodzinsky)

Bargylia norfolkiana Wygodzinsky, 1956. University of California Publications in Entomology 11: 199.

Leaylia norfolkiana (Wygodzinsky). Cassis \& Gross, 1995. Zoological Catalogue of Australia 27.3A: 199.

\section{ARADOIDEA}

\section{ARADIDAE}

\section{CALISIINAE}

Calisius leai Kormilev

Calisius leai Kormilev, 1966. Records of the South Australian Museum 15(2): 290, fig 21.

Calisius leai Kormilev. Holloway, 1977a. Lepidoptera of Norfolk Island, p. 270.

\section{CARVENTINAE}

Acaraptera minuta Kormilev

Acaraptera minuta Kormilev. Holloway, 1977a. Lepidoptera of Norfolk Island, p. 270. 


\section{LYGAEOIDEA}

\section{LYGAEIDAE}

\section{RHYPAROCHROMINAE}

Brentiscerus australis (Bergroth)

Brentiscerus australis (Bergroth). Holloway, 1977a. Lepidoptera of Norfolk Island, p. 270.

Lethaeus sp.

Lethaeus sp. (near aurantiacus Distant). Hawkins, 1943. Annals and Magazine of Natural History, London (11)9(60): 895.

Lethaeus sp. (near aurantiacus Distant). Holloway, 1977a. Lepidoptera of Norfolk Island, p. 270.

Remaudiereana inornatus (Walker)

Remaudiereana inornatus (Walker). Holloway, 1977a. Lepidoptera of Norfolk Island, p. 270.

\section{ORSILLINAE}

Nysius vinitor (Bergroth)

?Nysius sp. (near clevelandensis Evans). Hawkins, 1943. Annals and Magazine of Natural History, London (11)9(60): 895.

Nysius vinitor (Bergroth). Holloway, 1977a. Lepidoptera of Norfolk Island, p. 270.

\section{PENTATOMOIDEA}

\section{CYDNIDAE}

\section{CYDNINAE}

\section{Macroscytus sp.}

Macroscytus sp. Holloway, 1977a. Lepidoptera of Norfolk Island, p. 270.

\section{PENTATOMIDAE}

\section{PENTATOMINAE}

Alciphron glaucus (Fabricius)

Alciphron glaucus (Fabricius). Holloway, 1977a. Lepidoptera of Norfolk Island, p. 270.

Cermatulus nasalis (Westwood)

Cermatulus nasalis (Westwood). Holloway, 1977a. Lepidoptera of Norfolk Island, p. 270.

\section{Cuspicona norfolcensis Gross}

Cuspicona norfolcensis Gross, 1975. Records of the South Australian Museum 17(6): 138, figs. 47, 48c.

Cuspicona norfolcensis Gross. Holloway, 1977a. Lepidoptera of Norfolk Island, p. 270.

Cuspicona sp.

Cuspicona sp. Hawkins, 1943. Annals and Magazine of Natural History, London (11)9(60): 895.

Dictyotus caenosus (Westwood)

Dictyotus caenosus (Westwood). Hawkins, 1943. Annals and Magazine of Natural History, London (11)9(60): 895.

Dictyotus caenosus (Westwood). Holloway, 1977a. Lepidoptera of Norfolk Island, p. 270.

\section{Glaucias amyoti (White)}

Glaucias amyoti (White). Holloway, 1977a. Lepidoptera of Norfolk Island, p. 270.
Nezara viridula (Linnaeus)

Nezara viridula var. chlorocephala (Linnaeus). Hawkins, 1943. Annals and Magazine of Natural History, London (11)9(60): 895.

Nezara viridula (Linnaeus). Holloway, 1977a. Lepidoptera of Norfolk Island, p. 270.

Plautia sp.

Plautia sp. [possibly brunnipennis (Montrouzier)]. Holloway, 1977a. Lepidoptera of Norfolk Island, p. 270.

\section{THYSANOPTERA}

\section{TEREBRANTIA}

\section{THRIPIDAE}

THRIPINAE

Thrips hawaiiensis (Morgan)

Thrips hawaiiensis (Morgan). Mound, 1996. Zoological Catalogue of Australia 26: 285.

\section{TUBULIFERA}

\section{PHLAEOTHRIPIDAE}

\section{IDOLOTHRIPINAE}

Priesneriana uptoni (Mound)

Cryptothrips uptoni Mound, 1974. Australian Journal of Zoology, Supplementary Series 27: 44.

Priesneriana uptoni (Mound). Mound, 1996. Zoological Catalogue of Australia 26: 301.

\section{PHLAEOTHRIPINAE}

Phlaeothrips leai Karny

Phloeothrips leai Karny, 1925. Records of the South Australian Museum 3(1): 37, fig. 17.

Phloeothrips leai Karny. Hawkins, 1943. Annals and Magazine of Natural History, London (11)9(60): 899.

Phloesthrips leai Karny. Turner, Smithers \& Hoogland, 1968. The Conservation of Norfolk Island, p. 40. (Misprint of Phloeothrips).

Phloeothrips leai Karny. Holloway, 1977a. Lepidoptera of Norfolk Island, p. 271.

\section{NEUROPTERA}

\section{HEMEROBIOIDEA}

\section{HEMEROBIIDAE}

Carobius pulchellus Banks

Carobius pulchellus Banks. Tillyard, 1917. Proceedings of the Linnean Society of New South Wales 42: 533.

Carobius pulchellus Banks. Kimmins, 1941. Entomologist's monthly Magazine 77: 135.

Carobius pulchellus Banks. Hawkins, 1943. Annals and Magazine of Natural History, London (11)9(60): 899.

Carobius ?pulchellus Banks. New, 1987a. Invertebrate Taxonomy 1: 258, fig. 
Carobius pulchellus Banks. New, 1996. Zoological Catalogue of Australia 28: 38.

\section{Drepanacra binocula (Newman)}

Drepanacra norfolkensis Tillyard, 1917. Proceedings of the Linnean Society of New South Wales 42: 532.

Drepanacra instabilis insularis Tillyard, 1917. Proceedings of the Linnean Society of New South Wales 42: 532.

Drepanacra binocula insularis Tillyard. Kimmins, 1941. Entomologist's monthly Magazine 77: 135.

Drepanacra binocula norfolkensis Tillyard. Kimmins, 1941. Entomologist's monthly Magazine 77: 135.

Drepanacra binocula norfolkensis Tillyard. Hawkins, 1943. Annals and Magazine of Natural History, London (11)9(60): 899.

Drepanacra binocula insularis Tillyard. Hawkins, 1943. Annals and Magazine of Natural History, London (11)9(60): 899.

Drepanacra binocula (Newman). Wise, 1963. Pacific Insects 5(1): 54.

Drepanacra binocula norfolkensis Tillyard. Turner, Smithers \& Hoogland, 1968. The Conservation of Norfolk Island, p. 40.

Drepanacra binocula (Newman). Wise, 1973. New Zealand Entomologist 5(2): 184.

Drepanacra binocula (Newman). New, 1987a. Invertebrate Taxonomy 1: 258.

Drepanacra binocula (Newman). Wise, 1991. Records of the Auckland Institute and Museum 28: 219.

Drepanacra binocula (Newman). New, 1996. Zoological Catalogue of Australia 28: 39.

Micromus tasmaniae (Walker)

Micromus tasmaniae (Walker). Tillyard, 1917. Proceedings of the Linnean Society of New South Wales 42: 533.

Eumicromus tasmaniae (Walker). Kimmins, 1941. Entomologist's monthly Magazine 77: 135, 136.

Eumicromus tasmaniae (Walker). Hawkins, 1943. Annals and Magazine of Natural History, London (11)9(60): 899.

Micromus tasmaniae (Walker). Wise, 1963. Pacific Insects 5(1): 55.

Micromus tasmaniae (Walker). Wise, 1973. New Zealand Entomologist 5(2): 184.

Eumicromus tasmaniae (Walker). Holloway, 1977a. Lepidoptera of Norfolk Island, p. 271.

Micromus tasmaniae (Walker). New, 1987a. Invertebrate Taxonomy 1: 258, figs. 264-272, 323.

Micromus tasmaniae (Walker). Wise, 1991. Records of the Auckland Institute and Museum 28: 219.

Micromus tasmaniae (Walker). New, 1996. Zoological Catalogue of Australia 28: 40.

\section{CHRYSOPIDAE}

\section{APOCHRYSINAE}

Oligochrysa lutea (Walker)

Synthochrysa lutea (Walker). Kimmins, 1941. Entomologist's monthly Magazine 77: 135, 136.

Synthochrysa lutea (Walker). Hawkins, 1943. Annals and Magazine of Natural History, London (11)9(60): 899.

Synthochrysa lutea (Walker). Holloway, 1977a. Lepidoptera of Norfolk Island, p. 271.

Oligochrysa lutea (Walker). New, 1980. Australian Journal of Zoology, Supplementary Series 77: 4, figs. 1-12.

Oligochrysa lutea (Walker). New, 1987a. Invertebrate Taxonomy 1: 259.

\section{CHRYSOPINAE}

Apertochrysa anomala (Tillyard)

Chrysopa anomala Tillyard, 1917. Proceedings of the Linnean Society of New South Wales 42: 535, figs. 1b, 2.

Chrysopa anomala Tillyard. Kimmins, 1941. Entomologist's monthly Magazine 77: 135.

Chrysopa anomala Tillyard. Hawkins, 1943. Annals and Magazine of Natural History, London (11)9(60): 899.

Chrysopa anomala Tillyard. Kimmins, 1952. Annals and Magazine of Natural History, London (12)5: 90.

Chrysopa anomala Tillyard. New, 1987a. Invertebrate Taxonomy 1: 259, figs. 51, 52 .

Apertochrysa anomala (Tillyard). New, 1996. Zoological Catalogue of Australia 28: 46.

Apertochrysa leai (Tillyard)

Chrysopa leai Tillyard, 1917. Proceedings of the Linnean Society of New South Wales 42: 538, fig. 5.

Chrysopa leai Tillyard. Kimmins, 1941. Entomologist's monthly Magazine 77: 135.

Chrysopa leai Tillyard. Hawkins, 1943. Annals and Magazine of Natural History, London (11)9(60): 899.

Chrysopa leai Tillyard. Kimmins, 1952. Annals and Magazine of Natural History, London (12)5: 80.

Chrysopa leai Tillyard. New, 1987a. Invertebrate Taxonomy 1: 260, figs. 42, 43.

Apertochrysa leai (Tillyard). New, 1996. Zoological Catalogue of Australia 28: 47.

Apertochrysa nautarum (Tillyard)

Chrysopa nautarum Tillyard, 1917. Proceedings of the Linnean Society of New South Wales 42: 537, fig. 4.

Chrysopa nautarum Tillyard. Kimmins, 1941. Entomologist's monthly Magazine 77: 135.

Chrysopa nautarum Tillyard. Hawkins, 1943. Annals and Magazine of Natural History, London (11)9(60): 899.

Chrysopa nautarum Tillyard. Kimmins, 1952. Annals and Magazine of Natural History, London (12)5: 80.

Chrysopa nautarum Tillyard. New, 1987a. Invertebrate Taxonomy 1: 260, figs. 47, 48.

Apertochrysa nautarum (Tillyard). New, 1996. Zoological Catalogue of Australia 28: 47.

Apertochrysa norfolkensis (Tillyard)

Chrysopa norfolkensis Tillyard, 1917. Proceedings of the Linnean Society of New South Wales 42: 541, fig 8.

Chrysopa norfolkensis Tillyard. Kimmins, 1941. Entomologist's monthly Magazine 77: 135.

Chrysopa norfolkensis Tillyard. Hawkins, 1943. Annals and Magazine of Natural History, London (11)9(60): 899.

Chrysopa norfolkensis Tillyard. Kimmins, 1952. Annals and Magazine of Natural History, London (12)5: 80.

Chrysopa norfolkensis Tillyard. Turner, Smithers \& Hoogland, 1968. The Conservation of Norfolk Island, p. 40.

Chrysopa norfolkensis Tillyard. New, 1987a. Invertebrate Taxonomy 1: 266, figs. 28-41.

Apertochrysa norfolkensis (Tillyard). New, 1987a. Invertebrate Taxonomy 1: 267.

Apertochrysa norfolkensis (Tillyard). New, 1996. Zoological Catalogue of Australia 28: 47.

Apertochrysa waitei (Tillyard)

Chrysopa waitei Tillyard, 1917. Proceedings of the Linnean Society of New South Wales 42: 540, fig. 7.

Chrysopa waitei Tillyard. Kimmins, 1941. Entomologist's monthly Magazine 77: 135.

Chrysopa waitei Tillyard. Hawkins, 1943. Annals and Magazine of Natural History, London (11)9(60): 899. 
Chrysopa waitei Tillyard. Kimmins, 1952. Annals and Magazine of Natural History, London (12)5: 80.

Chrysopa waitei Tillyard. New, 1987a. Invertebrate Taxonomy 1: 260, figs. 44, 45.

Apertochrysa waitei (Tillyard). New, 1996. Zoological Catalogue of Australia 28: 47.

Chrysopa sp.

Chrysopa sp. Olliff, 1888a. Proceedings of the Linnean Society of New South Wales (2)2(4): 1014.

Chrysopa sp. Turner, Smithers \& Hoogland, 1968. The Conservation of Norfolk Island, p. 40.

Chrysopa sp. New, 1987b. Neuroptera International 4(3): 224, 5 figs.

Mallada araucariae (Tillyard)

Chrysopa araucariae Tillyard, 1917. Proceedings of the Linnean Society of New South Wales 42: 539, fig. 6.

Chrysopa ?araucariae Tillyard. Kimmins, 1941. Entomologist's monthly Magazine 77: 135, 136.

Chrysopa ?araucariae Tillyard. Hawkins, 1943. Annals and Magazine of Natural History, London (11)9(60): 899.

Chrysopa araucariae Tillyard. Kimmins, 1952. Annals and Magazine of Natural History, London (12)5: 80.

Chrysopa ?araucariae Tillyard. New, 1987a. Invertebrate Taxonomy 1: 260, figs. 15-27.

Chrysopa (Mallada) araucariae Tillyard. New, 1987a. Invertebrate Taxonomy 1: 266.

Mallada araucariae (Tillyard). New, 1996. Zoological Catalogue of Australia 28: 52.

Mallada metastigma (Tillyard)

Chrysopa metastigma Tillyard, 1917. Proceedings of the Linnean Society of New South Wales 42: 536, fig. 3.

Chrysopa metastigma Tillyard. Kimmins, 1941. Entomologist's monthly Magazine 77: 135.

Chrysopa metastigma Tillyard. Hawkins, 1943. Annals and Magazine of Natural History, London (11)9(60): 899.

Chrysopa metastigma Tillyard. Kimmins, 1952. Annals and Magazine of Natural History, London (12)5: 80.

Chrysopa (Mallada) metastigma Tillyard. New, 1987a. Invertebrate Taxonomy 1: 260, figs. 2-14.

Mallada metastigma (Tillyard). New, 1996. Zoological Catalogue of Australia 28: 53.

\section{MYRMELEONTOIDEA}

\section{MYRMELEONTIDAE}

\section{MYRMELEONTINAE}

Distoleon bistrigatus (Rambur)

Distoleon bistrigatus (Rambur). Holloway, 1977a. Lepidoptera of Norfolk Island, p. 271.

Distoleon bistrigatus (Rambur). New, 1987a. Invertebrate Taxonomy 1: 258.

Distoleon bistrigatus (Rambue). New, 1996. Zoological Catalogue of Australia 28: 77.

\section{COLEOPTERA}

\author{
ADEPHAGA
}

CARABOIDEA

\section{CARABIDAE}

\section{LEBIINAE}

Anomotarsus (Anomotarsus) discofoveatus Moore

Anomotarsus (Anomotarsus) discofoveatus Moore, 1985. The Carabidae of Norfolk Island, p. 254, figs. 7, 14.

Anomotarsus (Anomotarsus) discofoveatus Moore. Moore, Weir \& Pyke, 1987. Zoological Catalogue of Australia 4: 305.

\section{CALLISTINAE}

Chlaenius flaviguttatus Macleay

Chlaenius flaviguttatus Macleay. Moore, 1985. The Carabidae of Norfolk Island, p. 251.

Chlaenius flaviguttatus Macleay. Moore, Weir \& Pyke, 1987. Zoological Catalogue of Australia 4: 257.

Chlaenius ophonoides Fairmaire

!Chlaenius peregrinus Chaudoir. Olliff, 1888a. Proceedings of the Linnean Society of New South Wales (2)2(4): 1002 .

Chlaenius ophonoides Fairmaire. Hawkins, 1943. Annals and Magazine of Natural History, London (11)9(60): 884.

Chlaenius ophonoides Fairmaire. Moore, 1985. The Carabidae of Norfolk Island, p. 251.

Chlaenius ophonoides Fairmaire. Moore, Weir \& Pyke, 1987. Zoological Catalogue of Australia 4: 258.

\section{SCARITINAE}

Clivinia basalis Chaudoir

Clivinia basalis Chaudoir. Moore, 1985. The Carabidae of Norfolk Island, p. 244.

Clivinia basalis Chaudoir. Moore, Weir \& Pyke, 1987. Zoological Catalogue of Australia 4: 67.

\section{LICININAE}

Dicrochile idae Moore

Dicrochile sp. Hawkins, 1943. Annals and Magazine of Natural History, London (11)9(60): 884.

Dicrochile sp. Turner, Smithers \& Hoogland, 1968. The Conservation of Norfolk Island, p. 40.

Dicrochile idae Moore, 1985. The Carabidae of Norfolk Island, p. 249, fig. 4.

Dicrochile idae Moore, 1985. Moore, Weir \& Pyke, 1987. Zoological Catalogue of Australia 4: 264.

Lacordairea insulicola Moore

Lacordairea insulicola Moore, 1985. The Carabidae of Norfolk Island, p. 250, figs. 5, 12.

Lacordairea insulicola Moore. Moore, Weir \& Pyke, 1987. Zoological Catalogue of Australia 4: 266.

\section{HARPALINAE}

Euthenarus bicolor Moore

Euthenarus bicolor Moore, 1985. The Carabidae of Norfolk Island, p. 253, figs. 6, 13.

Euthenarus bicolor Moore. Moore, Weir \& Pyke, 1987. Zoological Catalogue of Australia 4: 244. 
Euthenarus promptus (Erichson)

Euthenarus promptus (Erichson). Moore, 1985. The Carabidae of Norfolk Island, p. 252.

Euthenarus promptus (Erichson). Moore, Weir \& Pyke, 1987. Zoological Catalogue of Australia 4: 245.

Gnathaphanus multipunctatus (Macleay)

Gnathaphanus multipunctatus (Macleay). Moore, 1992. The Carabidae of Lord Howe Island, p. 173.

Notiobia (Anisotarsus) melanaria (Dejean)

!Diaphoromerus iripennis [sic] Chaudoir. Olliff, 1888a. Proceedings of the Linnean Society of New South Wales (2)2(4): 1003. (Misspelling of "iridipennis").

!Diaphoromerus iridipennis Chaudoir. Hawkins, 1943. Annals and Magazine of Natural History, London (11)9(60): 885 .

Notiobia (Anisotarsus) melanaria (Dejean). Moore, 1985. The Carabidae of Norfolk Island, p. 252.

Notiobia (Anisotarsus) melanaria (Dejean). Moore, Weir \& Pyke, 1987. Zoological Catalogue of Australia 4: 234.

Notiobia melanaria (Dejean). Moore, 1992. The Carabidae of Lord Howe Island, pp. 162, 168.

\section{PTEROSTICHINAE}

Notagonum marginellum (Erichson)

Notagonum marginellum (Erichson). Moore, 1985. The Carabidae of Norfolk Island, p. 247.

Notagonum marginellum (Erichson). Moore, Weir \& Pyke, 1987. Zoological Catalogue of Australia 4: 221.

Notagonum marginellum (Erichson). Moore, 1992. The Carabidae of Lord Howe Island, p. 162.

Notagonum submetallicum (White)

Notagonum submetallicum (White). Moore, 1985. The Carabidae of Norfolk Island, p. 247.

Notagonum submetallicum (White). Moore, Weir \& Pyke, 1987. Zoological Catalogue of Australia 4: 221.

Notoplatynus darlingtoni Moore

?Agonum sp. Hawkins, 1943. Annals and Magazine of Natural History, London (11)9(60): 884.

?Agonum sp. Turner, Smithers \& Hoogland, 1968. The Conservation of Norfolk Island, p. 40.

Notoplatynus darlingtoni Moore, 1985. The Carabidae of Norfolk Island, p. 248, figs. 3, 11

Notoplatynus darlingtoni Moore, 1985. Moore, Weir \& Pyke, 1987. Zoological Catalogue of Australia 4: 221.

Pentagonica atkinsoni Fauvel

Pentagonica atkinsoni Fauvel. Moore, 1985. The Carabidae of Norfolk Island, p. 255.

Pentagonica atkinsoni Fauvel. Moore, Weir \& Pyke, 1987. Zoological Catalogue of Australia 4: 272.

Pseudoceneus (Poeciliridius) norfolkensis Moore

Pseudoceneus (Poeciliridius) norfolkensis Moore, 1985. The Carabidae of Norfolk Island, p. 246, figs. 2, 10.

Pseudoceneus (Poeciliridius) norfolkensis Moore. Moore, Weir \& Pyke, 1987. Zoological Catalogue of Australia 4: 214.

\section{PSYDRINAE}

Mecylothorax monteithi Moore

Mecylothorax monteithi Moore, 1985. The Carabidae of Norfolk Island, p. 245, figs. 1, 9.

Mecylothorax monteithi Moore. Moore, Weir \& Pyke, 1987. Zoological Catalogue of Australia 4: 148.

\section{CARABINAE}

Illaphanus stephensii Macleay

Illaphanus stephensii Macleay. Moore, 1992. The Carabidae of Lord Howe Island pp. 165, 173.

\section{GYRINIDAE}

Aulonogyrus sp.

Aulonogyrus sp. Hawkins, 1943. Annals and Magazine of Natural History, London (11)9(60): 885.

Aulonogyrus sp. Turner, Smithers \& Hoogland, 1968. The Conservation of Norfolk Island, p. 40.

Aulonogyrus strigosus (Fabricius)

Aulonogyrus strigosus (Fabricius). Lawrence, Weir \& Pyke, 1987. Zoological Catalogue of Australia 4: 362.

\section{POLYPHAGA}

\section{HYDROPHILOIDEA}

\section{HYDROPHILIDAE}

\section{SPHAERIDIINAE}

Cercyon haemorrhoidalis Fabricius

Cercyon haemorrhoidalis Fabricius. Ferrar, Standfast \& Dyce, 1975. Journal of the Australian entomological Society 14: 11 .

Cercyon sp. Hawkins, 1943. Annals and Magazine of Natural History, London (11)9(60): 887.

\section{HISTERIDAE}

\section{Acritus norfolcensis Lea}

Acritus norfolcensis Lea, 1924a. Transactions of the entomological Society of London 57: 260.

Acritus norfolcensis Lea. Hawkins, 1943. Annals and Magazine of Natural History, London (11)9(60): 886.

Acritus norfolcensis Lea. Turner, Smithers \& Hoogland, 1968. The Conservation of Norfolk Island, p. 40.

\section{STAPHYLINOIDEA}

\section{PTILIIDAE}

Acrotrichis norfolkensis (Deane)

Trichopteryx norfolkensis Deane, 1931. Proceedings of the Linnean Society of New South Wales 56: 234, fig. 13.

Acrotrichis norfolkensis (Deane). Hawkins, 1943. Annals and Magazine of Natural History, London (11)9(60): 886.

Acrotrichis norfolkensis (Deane). Turner, Smithers \& Hoogland, 1968. The Conservation of Norfolk Island, p. 40.

\section{STAPHYLINIDAE}

\section{ALEOCHARINAE}

Atheta spp.

Atheta spp. Hawkins, 1943. Annals and Magazine of Natural History, London (11)9(60): 885.

Atheta spp. Turner, Smithers \& Hoogland, 1968. The Conservation of Norfolk Island, p. 40. 


\section{PAEDERINAE}

Astenus guttulus (Fauvel)

Astenus guttulus (Fauvel). Lea, 1923. Transactions and Proceedings of the Royal Society of South Australia 47: 17.

Astenus guttula (Fauvel). Hawkins, 1943. Annals and Magazine of Natural History, London (11)9(60): 885.

Medon debilicornis (Wollaston)

Medon debilicornis (Wollaston). Lea,1923. Transactions and Proceedings of the Royal Society of South Australia 47: 22.

Medon debilicornis (Wollaston). Hawkins, 1943. Annals and Magazine of Natural History, London (11)9(60): 885.

\section{STAPHYLININAE}

Creophilus erythrocephalus (Fabricius)

Creophilus erythrocephalus (Fabricius). Olliff, 1888a. Proceedings of the Linnean Society of New South Wales (2)2(4): 1003.

Creophilus erythrocephalus (Fabricius). Hawkins, 1943. Annals and Magazine of Natural History, London (11)9(60): 885 .

Philonthus longicornis Stephens

Philonthus longicornis Stephens. Lea, 1925. Transactions and Proceedings of the Royal Society of South Australia 49: 220.

Philonthus longicornis Stephens. Hawkins, 1943. Annals and Magazine of Natural History, London (11)9(60): 885.

Philonthus longicornis Stephens. Ferrar, Standfast \& Dyce, 1975. Journal of the Australian entomological Society 14: 11 .

\section{XANTHOLININAE}

\section{Leptacinus opacipennis Lea}

Leptacinus opacipennis Lea, 1925. Transactions and Proceedings of the Royal Society of South Australia 49: 218.

Leptacinus opacipennis Lea. Hawkins, 1943. Annals and Magazine of Natural History, London (11)9(60): 885.

Zeteotomus rufulus (Broun)

Metoponcus rufulus var. norfolkensis Lea, 1925. Transactions and Proceedings of the Royal Society of South Australia 49: 214.

Metoponcus rufulus var. norfolkensis Lea. Hawkins, 1943. Annals and Magazine of Natural History, London (11)9(60): 885 .

\section{OMALIINAE}

Omalium (?Phloeonomus) sp.

Omalium (?Phloeonomus) sp. Hawkins, 1943. Annals and Magazine of Natural History, London (11)9(60): 885.

\section{SCARABAEOIDEA}

\section{LUCANIDAE}

\section{LAMPRIMINAE}

Lamprima aenea (Fabricius)

Lethrus aeneus Fabricius, 1792. Entomologia systematica emendata... etc. 1(1): 2 .

Lucanus aeneus (Fabricius). Donovan, 1805. An epitome of the natural history of the Insects of New Holland, New Zealand... etc. Text and plate not numbered.
Lamprima aenea (Fabricius). Olliff, 1888a. Proceedings of the Linnean Society of New South Wales (2)2(4): 1004.

Lamprima aenea (Fabricius). Hawkins, 1943. Annals and Magazine of Natural History, London (11)9(60): 888.

Lamprima aenea (Fabricius). Moore \& Cassis, 1992. Zoological Catalogue of Australia 9: 6.

\section{SYNDESINAE}

Syndesus cornutus (Fabricius)

Syndesus cornutus (Fabricius). Moore \& Cassis, 1992. Zoological Catalogue of Australia 9: 19.

\section{SCARABAEIDAE}

\section{APHODIINAE}

Aphodius lividus (Olivier)

Aphodius lividus (Olivier). Ferrar, Standfast \& Dyce, 1975. Journal of the Australian entomological Society 14: 11.

Aphodius (Nialus) pseudolividus Balthasar

Aphodius (Nialus) pseudolividus Balthasar. Cassis \& Weir, 1992a. Zoological Catalogue of Australia 9: 89.

Ataenius picinus Harold

Ataenius picinus Harold. Cassis \& Weir, 1992a. Zoological Catalogue of Australia 9: 97.

Ataenius sp.

Ataenius sp. Hawkins, 1943. Annals and Magazine of Natural History, London (11)9(60): 889.

\section{SCARABAEINAE}

Euoniticellus africanus (Harold)

Euoniticellus africanus (Harold). Ferrar, Standfast \& Dyce, 1975. Journal of the Australian entomological Society 14: 13 .

Euoniticellus intermedius (Reiche)

Euoniticellus intermedius (Reiche). Ferrar, Standfast \& Dyce, 1975. Journal of the Australian entomological Society 14: 13 .

Onitis alexis Klug

Onitis alexis Klug. Ferrar, Standfast \& Dyce, 1975. Journal of the Australian entomological Society 14: 13.

Onitis vanderkelleni Lansberge

Onitis vanderkelleni Lansberge. Cassis \& Weir, 1992b. Zoological Catalogue of Australia 9: 121.

Onthophagus binodis Thunberg

Onthophagus binodis Thunberg. Ferrar, Standfast \& Dyce, 1975. Journal of the Australian entomological Society 14: 13.

Onthophagus binodis Thunberg. Cassis \& Weir, 1992b. Zoological Catalogue of Australia 9: 126.

Onthophagus gazella (Fabricius)

Onthophagus gazella (Fabricius). Ferrar, Standfast \& Dyce, 1975. Journal of the Australian entomological Society 14: 13 .

Onthophagus gazella (Fabricius). Cassis \& Weir, 1992b. Zoological Catalogue of Australia 9: 135.

Onthophagus nigriventris d'Orbigny

Onthophagus nigriventris d'Orbigny. Cassis \& Weir, 1992b. Zoological Catalogue of Australia 9: 143. 


\section{DYNASTINAE}

Heteronychus arator (Fabricius)

Heteronychus arator (Fabricius). Ferrar, Standfast \& Dyce, 1975. Journal of the Australian entomological Society 14: 11.

Heteronychus arator (Fabricius). Cassis \& Weir, 1992c. Zoological Catalogue of Australia 9: 401.

Pimelopus fischeri (Montrouzier)

Chiroplatys lissus Olliff, 1888a. Proceedings of the Linnean Society of New South Wales (2)2(4): 1004. (Misspelling of Cheiroplatys).

Pimelopus lissus (Olliff). Hawkins, 1943. Annals and Magazine of Natural History, London (11)9(60): 889.

Pimelopus lissus (Olliff). Turner, Smithers \& Hoogland, 1968. The Conservation of Norfolk Island, p. 40.

Pimelopus fischeri (Montrouzier). Cassis \& Weir, 1992c. Zoological Catalogue of Australia 9: 410.

\section{CETONIINAE}

Chlorobapta bestii (Westwood)

Schizorhina bestii Westwood, 1842. Arcana Entomologica. 1(7): 103; pl. xxxviii, figs. 2a-c. (See Best, 1966).

Schizorhina bestii Westwood. Iredale \& Whitley, 1969. Proceedings of the Royal zoological Society of New South Wales (1967-1968): 32.

Chlorobapta bestii (Westwood). Cassis \& Weir, 1992d. Zoological Catalogue of Australia 9: 434.

\section{BUPRESTOIDEA}

\section{BUPRESTIDAE}

\section{BUPRESTINAE}

Melobasis purpurascens (Fabricius)

Melobasis purpurascens (Fabricius). Olliff, 1888a. Proceedings of the Linnean Society of New South Wales (2)2(4): 1005.

Melobasis purpurascens (Fabricius). Hawkins, 1943. Annals and Magazine of Natural History, London (11)9(60): 888.

\section{ELATEROIDEA}

\section{EUCNEMIDAE}

\section{Fornax norfolkensis Lea}

Fornax norfolkensis Lea, 1916. Transactions and Proceedings of the Royal Society of South Australia 40: 319.

Fornax norfolkensis Lea. Lea, 1929. Transactions and Proceedings of the Royal Society of South Australia 53: 213.

Fornax norfolkensis Lea. Hawkins. 1943. Annals and Magazine of Natural History, London (11)9(60): 887.

Fornax norfolkensis Lea. Turner, Smithers \& Hoogland, 1968. The Conservation of Norfolk Island, p. 40.

\section{ELATERIDAE}

\section{AGRYPNINAE}

Conoderus sp.

Monocrepidus sp. Olliff, 1888a. Proceedings of the Linnean Society of New South Wales (2)2(4): 1005.

Conoderus sp. (close to striatus). Hawkins, 1943. Annals and Magazine of Natural History, London (11)9(60): 887.
Conoderus ?striatus (Macleay)

Monocrepidus striatus Macleay. Olliff, 1888a. Proceedings of the Linnean Society of New South Wales (2)2(4): 1005.

Conoderus ?striatus (Macleay). Hawkins, 1943. Annals and Magazine of Natural History, London (11)9(60): 887.

Paracalais nesiotes Neboiss

Paracalais nesiotes Neboiss, 1967. Proceedings of the Royal Society of Victoria 80: 268; pl. 43, fig. 4.

Paracalais nesiotes Neboiss. Holloway, 1977a. Lepidoptera of Norfolk Island, p. 271.

\section{ELATERINAE}

Dicteniophorus ramifer (Eschscholtz)

Dicteniophorus ramifer (Eschscholtz). Olliff, 1888a. Proceedings of the Linnean Society of New South Wales (2)2(4): 1005.

Dicteniophorus ramifer (Eschscholtz). Hawkins, 1943. Annals and Magazine of Natural History, London (11)9(60): 887 .

Glyptochilus basicollis Lea

Glyptochilus basicollis Lea, 1929. Transactions and Proceedings of the Royal Society of South Australia 43: 214.

Glyptochilus basicollis Lea. Hawkins, 1943. Annals and Magazine of Natural History, London (11)9(60): 887.

Glyptochilus basicollis Lea. Turner, Smithers \& Hoogland, 1968. The Conservation of Norfolk Island, p. 40.

Megapenthes sp.

Megapenthes sp. Holloway, 1977a. Lepidoptera of Norfolk Island, p. 271.

\section{PYROPHORINAE}

\section{Heteroderes sp.}

Heteroderes sp. Holloway, 1977a. Lepidoptera of Norfolk Island, p. 271.

\section{DENTICOLLINAE}

Onchosternus norfolcensis Lea

Onchosternus norfolcensis Lea, 1929. Transactions and Proceedings of the Royal Society of South Australia 53: 216.

Onchosternus norfolcensis Lea. Hawkins, 1943. Annals and Magazine of Natural History, London (11)9(60): 887.

Onchosternus norfolcensis Lea. Turner, Smithers \& Hoogland, 1968. The Conservation of Norfolk Island, p. 40.

\section{LUDIINAE}

Thoramus sp.

Thoramus sp. Holloway, 1977a. Lepidoptera of Norfolk Island, p. 271.

\section{BOSTRICHOIDEA}

\section{BOSTRICHIDAE}

\section{BOSTRICHINAE}

Xylion sp.

Rhizopertha sp. (near R. collaris Erichson). Olliff. 1888a. Transactions of the Linnean Society of New South Wales (2)2(4): 1006.

Xylion sp. (near X. (Rhizopertha) collaris Er.). Hawkins, 1943. Annals and Magazine of Natural History, London (11)9(60): 887.

Xylion sp.(near X.(R.) collaris Er.). Turner, Smithers \& Hoogland, 1968. The Conservation of Norfolk Island, p. 40. 


\section{ANOBIIDAE}

Calymmaderus pulverulens Lea

Calymmaderus pulverulens Lea, 1924b. Transactions and Proceedings of the Royal Society of South Australia 48: 52, fig. 27.

Calymmaderus pulverulens Lea. Hawkins, 1943. Annals and Magazine of Natural History, London (11)9(60): 887.

Calymmaderus pulverulens Lea. Turner, Smithers \& Hoogland, 1968. The Conservation of Norfolk Island, p. 40.

Dorcatoma rhizobioides Lea

Dorcatoma rhizobioides Lea, 1924b. Transactions and Proceedings of the Royal Society of South Australia 48: 63, fig. 38.

Dorcatoma rhizobioides Lea. Hawkins, 1943. Annals and Magazine of Natural History, London (11)9(60): 887.

Dorcatoma rhizobioides Lea. Turner, Smithers \& Hoogland, 1968. The Conservation of Norfolk Island, p. 40.

\section{Dorcatoma norfolcensis Lea}

Dorcatoma norfolcensis Lea, 1924b. Transactions and Proceedings of the Royal Society of South Australia 48: 63. (Maybe a variety of $D$. punctilatera Lea, loc. cit. p. 62).

Dorcatoma norfolcensis Lea. Hawkins, 1943. Annals and Magazine of Natural History, London (11)9(60): 887.

Dorcatoma norfolcensis Lea. Turner, Smithers \& Hoogland, 1968. The Conservation of Norfolk Island, p. 40.

Pronus marmoratus Lea

Pronus marmoratus Lea, 1924b. Transactions and Proceedings of the Royal Society of South Australia 48: 51.

Pronus marmoratus Lea. Hawkins, 1943. Annals and Magazine of Natural History, London (11)9(60): 887.

Pronus marmoratus Lea. Turner, Smithers \& Hoogland, 1968. The Conservation of Norfolk Island, p. 40.

\section{CLEROIDEA}

\section{TROGOSSITIDAE}

\section{TROGOSSITINAE}

\section{Lepidopteryx (Leperina) turbata (Pascoe)}

Leperina turbata Pascoe. Olliff, 1888a. Proceedings of the Linnean Society of New South Wales (2)2(4): 1004.

Leperina turbata Pascoe. Hawkins. 1943. Annals and Magazine of Natural History, London (11)9(60): 886.

\section{CUCUJOIDEA}

\section{NITIDULIDAE}

Epuraea sp.

Epuraea sp. Hawkins, 1943. Annals and Magazine of Natural History, London (11)9(60): 886.

Lasiodactylus calvus Olliff

Lasiodactylus calvus Olliff, 1888a. Proceedings of the Linnean Society of New South Wales (2)2(4): 1003.

Lasiodactylus calvus Olliff. Hawkins, 1943. Annals and Magazine of Natural History, London (11)9(60): 886.

Lasiodactylus calvus Olliff. Turner, Smithers \& Hoogland, 1968. The Conservation of Norfolk Island, p. 40.

\section{SILVANIDAE}

Cryptamorpha desjardinsi Guérin-Méneville

Cryptamorpha desjardinsi Guérin-Méneville. Hawkins, 1943. Annals and Magazine of Natural History, London (11)9(60): 886.

\section{LAEMOPHLOEIDAE}

Laemophloeus norfolcensis Lea

Laemophloeus norfolcensis Lea, 1929. Transactions and Proceedings of the Royal Society of South Australia 53: 210 .

Laemophloeus norfolcensis Lea. Hawkins, 1943. Annals and Magazine of Natural History, London (11)9(60): 886.

Laemophloeus norfolcensis Lea. Turner, Smithers \& Hoogland, 1968. The Conservation of Norfolk Island, p. 40.

\section{COCCINELLIDAE}

Chilomenes polynesiae Crotch

Chilomenes polynesiae Crotch, 1874. A revision of the coleopterous family Coccinellidae p. 181.

Chilomenes polynesiae Crotch. Hawkins, 1943. Annals and Magazine of Natural History, London (11)9(60): 886, 887. (?=duodecimpunctata Fauvel).

Coelophora inaequalis (Fabricius)

Coelophora inaequalis (Fabricius). Pope, 1988. Invertebrate Taxonomy 2: 665, figs. 26-29, 53, 67, 74, 78, 124-126.

Harmonia testudinaria (Mulsant)

Harmonia testudinaria (Mulsant). Pope, 1988. Invertebrate Taxonomy 2: 687, figs. 9, 10, 85, 157-160.

Rhyzobius erythrogaster Lea

Rhyzobius erythrogaster Lea, 1929. Transactions and Proceedings of the Royal Society of South Australia 53: 241 .

Rhyzobius erythrogaster Lea. Hawkins, 1943. Annals and Magazine of Natural History, London (11)9(60): 886.

Rhyzobius erythrogaster Lea. Turner, Smithers \& Hoogland, 1968. The Conservation of Norfolk Island, p. 40.

Scymnus pumilio Wollaston

Scymnus flavifrons var. norfolkensis Lea, 1929. Transactions and Proceedings of the Royal Society of South Australia 53: 244.

Scymnus pumilio var. norfolkensis Lea. Hawkins, 1943. Annals and Magazine of Natural History, London (11)9(60): 886.

Scymnus spp.

Scymnus spp. (4 spp.). Hawkins, 1943. Annals and Magazine of Natural History, London (11)9(60): 886.

Stethorus obscuripennis (Lea)

Scymnus obscuripennis Lea, 1929. Transactions and Proceedings of the Royal Society of South Australia 53: 243.

Scymnus obscuripennis Lea. Hawkins, 1943. Annals and Magazine of Natural History, London (11)9(60): 886.

Scymnus obscuripennis Lea. Turner, Smithers \& Hoogland, 1968. The Conservation of Norfolk Island, p. 40.

Stethorus obscuripennis (Lea). Houston, 1983. Journal of the Australian entomological Society 22(3): 185, figs. 1-8. 


\section{CORYLOPHIDAE}

\section{SERICODERINAE}

Sericoderus sp.

Sericoderus sp. Hawkins, 1943. Annals and Magazine of Natural History, London (11)9(60): 885.

Sericoderus sp. Turner, Smithers \& Hoogland, 1968. The Conservation of Norfolk Island, p. 40.

\section{TENEBRIONOIDEA}

\section{MORDELLIDAE}

\section{Mordella norfolcensis Lea}

Mordella norfolcensis Lea, 1917. Transactions and Proceedings of the Royal Society of South Australia 41: 235; pl. xv, figs. 103-105. (may be var. of M. hamatalis). Mordella norfolcensis Lea. Hawkins, 1943. Annals and Magazine of Natural History, London (11)9(60): 888.

\section{TENEBRIONIDAE}

\section{Araucariola ebenina Lea}

Araucariola ebenina Lea, 1929. Transactions and Proceedings of the Royal Society of South Australia 53: 218.

Araucariola ebenina Lea. Hawkins, 1943. Annals and Magazine of Natural History, London (11)9(60): 888.

\section{Brachycilibe araucariae Lea}

Brachycilibe araucariae Lea, 1929. Transactions and Proceedings of the Royal Society of South Australia 53: 219.

Brachycilibe araucariae Lea. Hawkins, 1943. Annals and Magazine of Natural History, London (11)9(60): 888.

Gnathocerus cornutus (Fabricius)

Gnathocerus cornutus (Fabricius). Hawkins, 1943. Annals and Magazine of Natural History, London (11)9(60): 888.

Gonocephalum insulanum (Olliff)

Hopatrum insulanum Olliff, 1888a. Proceedings of the Linnean Society of New South Wales (2)2(4): 1006.

Gonocephalum insulanum (Olliff). Hawkins, 1943. Annals and Magazine of Natural History, London (11)9(60): 888.

Gonocephalum insulanum (Olliff). Turner, Smithers \& Hoogland, 1968. The Conservation of Norfolk Island, p. 40 .

Lorelus sp.

Lorelus sp. Hawkins, 1943. Annals and Magazine of Natural History, London (11)9(60): 888.

\section{Mesotretis fumata Lea}

Mesotretis fumata Lea, 1929. Transactions and Proceedings of the Royal Society of South Australia 53: 217.

Mesotretis fumata Lea. Hawkins, 1943. Annals and Magazine of Natural History, London (11)9(60): 888.

Mesotretis fumata Lea. Turner, Smithers \& Hoogland, 1968. The Conservation of Norfolk Island, p. 40.

\section{Mesotretis glabra Lea}

Mesotretis glabra Lea, 1929. Transactions and Proceedings of the Royal Society of South Australia 53: 218.

Mesotretis glabra Lea. Hawkins, 1943. Annals and Magazine of Natural History, London (11)9(60): 888.

\section{Metisopus purpureipennis Bates}

Metisopus purpureipennis Bates, 1873. Transactions of the entomological Society of London 1873: 371.
Metisopus purpureipennis Bates. Olliff, 1888a. Proceedings of the Linnean Society of New South Wales (2)2(4): 1006.

Metisopus purpureipennis Bates. Hawkins, 1943. Annals and Magazine of Natural History, London (11)9(60): 888.

\section{ANTHICIDAE}

Anthicus strictus Erichson

Anthicus strictus Erichson. Hawkins, 1943. Annals and Magazine of Natural History, London (11)9(60): 888.

\section{ADERIDAE}

Euglendeles norfolcensis (Lea)

Xylophilus norfolcensis Lea, 1917. Transactions and Proceedings of the Royal Society of South Australia 41: 186.

Euglendeles norfolcensis (Lea). Hawkins, 1943. Annals and Magazine of Natural History, London (11)9(60): 888.

\section{CHRYSOMELOIDEA}

\section{CERAMBYCIDAE}

\section{PRIONINAE}

Cacodacnus hebridanus Thomson

Toxeutes rasalis Olliff, 1888a. Proceedings of the Linnean Society of New South Wales (2)2(4): 1010.

Toxeutes rasalis Olliff. Olliff, 1890. Records of the Australian Museum 1: 72; pl. 10, fig. 1.

Cacodacnus hebridanus Thomson. Hawkins, 1943. Annals and Magazine of Natural History, London (11)9(60): 891.

Toxeutes macleayi (Pascoe)

Toxeutes macleayi Pascoe. Holloway, 1977a. Lepidoptera of Norfolk Island, p. 272.

\section{PARANDRINAE}

Parandra ?araucariae Gressitt

Parandra ?araucariae Gressitt. Holloway, 1977a. Lepidoptera of Norfolk Island, p. 272.

\section{CERAMBYCINAE}

Ceresium flavipes (Fabricius)

Ceresium simplex (Gyllenhall). Olliff, 1888a. Proceedings of the Linnean Society of New South Wales (2)2(4): 1011.

Ceresium flavipes (Fabricius). Hawkins, 1943. Annals and Magazine of Natural History, London (11)9(60): 891.

Diotimana undulata (Pascoe)

Diotima undulata Pascoe. Olliff, 1888a. Proceedings of the Linnean Society of New South Wales (2)2(4): 1011.

Diotimana undulata (Pascoe). Hawkins, 1943. Annals and Magazine of Natural History, London (11)9(60): 891.

Diotimana undulata (Pascoe). Holloway, 1977a. Lepidoptera of Norfolk Island, p. 271.

Dysthaeta naevia Olliff

Dysthaeta naevia Olliff, 1888a. Proceedings of the Linnean Society of New South Wales (2)2(4): 1011.

Dysthaeta naevia Olliff. Hawkins, 1943. Annals and Magazine of Natural History, London (11)9(60): 1011.

Dysthaeta naevia Olliff. Turner, Smithers \& Hoogland, 1968. The Conservation of Norfolk Island, p. 40.

Neobethelium megacephalum Blackburn

Neobethelium megacephalum Blackburn. Holloway, 1977a. Lepidoptera of Norfolk Island, p. 271. 
Porithea intorta (Newman)

Porithea intorta (Newman). Holloway, 1977a. Lepidoptera of Norfolk Island, p. 271.

\section{LAMIINAE}

Enicodes fichteli (Schreibers)

Enicodes fichteli (Schreibers). Olliff, 1888a. Proceedings of the Linnean Society of New South Wales (2)2(4): 1013.

Enicodes fichteli (Schreibers). Hawkins, 1943. Annals and Magazine of Natural History, London (11)9(60): 892.

Enicodes sp.

Enicodes sp. Hawkins, 1943. Annals and Magazine of Natural History, London (11)9(60): 892.

Enicodes sp. Turner, Smithers \& Hoogland, 1968. The Conservation of Norfolk Island, p. 40.

Microlamia norfolkensis Breuning

Microlamia norfolkensis Breuning, 1948. Arkiv f. Zoologie 39(A): 4

Microlamia norfolkensis Breuning. Turner, Smithers \& Hoogland, 1968. The Conservation of Norfolk Island, p. 40.

Microlamia norfolkensis Breuning. Holloway, 1977a. Lepidoptera of Norfolk Island, p. 272.

Mimoxylotoles norfolkensis Breuning

Xyloteles sp. Hawkins, 1943. Annals and Magazine of Natural History, London (11)9(60): 892.

Mimoxylotoles norfolkensis Breuning, 1962. Annals and Magazine of Natural History, London (13)5: 241.

Mimoxylotoles norfolkensis Breuning. Holloway, 1977a. Lepidoptera of Norfolk Island, p. 272.

Parapteridotelus norfolkensis Breuning

Xyloteles sp. Hawkins, 1943. Annals and Magazine of Natural History, London (11)9(60): 891.

Parapteridotelus norfolkensis Breuning, 1962. Annals and Magazine of Natural History, London (13)5: 240.

Parapteridotelus norfolkensis Breuning. Holloway, 1977a. Lepidoptera of Norfolk Island, p. 272.

Xyloteles pattesoni Olliff

Xyloteles pattesoni Olliff, 1888a. Proceedings of the Linnean Society of New South Wales (2)2(4): 1012.

Xyloteles pattesoni Olliff. Hawkins, 1943. Annals and Magazine of Natural History, London (11)9(60): 891.

Xyloteles pattesoni Olliff. Holloway, 1977a. Lepidoptera of Norfolk Island, p. 272.

Xyloteles selwyni Olliff

Xyloteles selwyni Olliff, 1888a. Proceedings of the Linnean Society of New South Wales (2)2(4): 1012.

Xyloteles selwyni Olliff. Hawkins, 1943. Annals and Magazine of Natural History, London (11)9(60): 891.

Xyloteles selwyni Olliff. Holloway, 1977a. Lepidoptera of Norfolk Island, p. 272.

Xyloteles spp.

Xyloteles spp. Hawkins, 1943. Annals and Magazine of Natural History, London (11)9(60): 891.

Zygocera norfolkensis McKeown

Zygocera norfolkensis McKeown, 1938. Records of the Australian Museum 20(3): 211; pl. XXIII, fig. 1.

Zygocera norfolkensis McKeown. Hawkins, 1943. Annals and Magazine of Natural History, London (11)9(60): 892.

Zygocera norfolkensis McKeown. Turner, Smithers \& Hoogland, 1968. The Conservation of Norfolk Island, p. 40 .

\section{CHRYSOMELIDAE}

\section{HISPINAE}

Brontispa norfolkensis Gressitt

Brontispa norfolkensis Gressitt, 1960. Pacific Insects 2: 19, fig. $4 \mathrm{c}$.

Brontispa norfolkensis Gressitt. Holloway, 1977a. Lepidoptera of Norfolk Island, p. 271.

\section{GALERUCINAE}

Argopistes armipes (Lea)

Sphaerophyma armipes Lea, 1926a. Transactions and Proceedings of the Royal Society of South Australia 50: 80 .

Sphaerophyma armipes Lea. Hawkins, 1943. Annals and Magazine of Natural History, London (11)9(60): 892.

Argopistes armipes (Lea). Samuelson, 1973. Pacific Insects Monographs 30: 69, fig. 30.

Argopistes armipes (Lea). Holloway, 1977a. Lepidoptera of Norfolk Island, p. 271.

\section{Chaetocnema (Chaetocnema) paspalae (Broun)}

Chaetocnema (Chaetocnema) paspalae (Broun). Samuelson, 1973. Pacific Insects Monographs 30: 134, figs. 16n, 30a.

Chaetocnema paspalae (Broun). Holloway, 1977a. Lepidoptera of Norfolk Island, p. 271.

Pleuraltica tyche Samuelson

Pleuraltica tyche Samuelson, 1973. Pacific Insects Monographs 30: 35, figs. 13a, 26p.

Pleuraltica tyche Samuelson. Holloway, 1977a. Lepidoptera of Norfolk Island, p. 271.

Psylliodes brettinghami Baly

Psylliodes lubricata norfolcensis Lea, 1929. Transactions and Proceedings of the Royal Society of South Australia 53: 239.

Psylliodes lubricata norfolcensis Lea. Hawkins, 1943. Annals and Magazine of Natural History, London (11)9(60): 892.

Psylliodes brettinghami Baly. Samuelson, 1973. Pacific Insects Monographs 30: 144, figs. 17g, 30i, 39.

Psylliodes brettinghami Baly. Holloway, 1977a. Lepidoptera of Norfolk Island, p. 271.

\section{EUMOLPINAE}

Colaspoides norfolcensis Lea

Colaspoides norfolcensis Lea, 1915. Transactions and Proceedings of the Royal Society of South Australia 39: 281.

Eucolaspis brunnea (Fabricius)

?Colaspis sp. Olliff, 1888a. Proceedings of the Linnean Society of New South Wales (2)2(4): 1013.

Eucolaspis brunnea (Fabricius). Hawkins, 1943. Annals and Magazine of Natural History, London (11)9(60): 892. (This record is probably incorrect, the material probably belonging to the variable Colaspoides norfolcensis. E. brunnea is a New Zealand species [C. Reid, pers com.]).

\section{CURCULIONOIDEA}

Note: The arrangement of the Curculionoidea follows that of Zimmerman (1991, 1992, 1993, 1994a,b). Groups not dealt with in these publications are arranged alphabetically pending publication of the remaining volumes of Zimmerman's Australian Weevils. 


\section{ANTHRIBIDAE}

\section{ANTHRIBINAE}

Cacephatus sp.

Cacephatus sp. Zimmerman, 1994a. Australian Weevils 1: $14,76$.

Gen. nov. et sp. nov.

Gen. nov. et sp. nov. Zimmerman, 1994a. Australian Weevils 1: $19,187$.

\section{CHORAGINAE}

Araeocerodes spp.

Araeocerodes spp. Zimmerman, 1994a. Australian Weevils 1: $22,223$.

Stenorhis spp.

Stenorhis spp. Zimmerman, 1994a. Australian Weevils 1: $23,231$.

Gen. nov. et sp. nov.

Gen. nov. et sp. nov. Zimmerman, 1994a. Australian Weevils 1: $23,231$.

\section{BRENTIDAE}

\section{BRENTINAE}

Araiorrhinus howitti (Pascoe)

Araiorrhinus howitti (Pascoe). Zimmerman, 1994b. Australian Weevils 2: 8, 184, fig. 187.

Euschizus internatus (Pascoe)

Euschizus internatus (Pascoe). Zimmerman, 1994b. Australian Weevils 2: 8, 201, fig. 201.

\section{CURCULIONIDAE}

\section{RHYTIRHININAE}

Listroderes obliquus Gyllenhall

Listroderes obliquus Gyllenhall. Hawkins, 1943. Annals and Magazine of Natural History, London (11)9(60): 890.

\section{CRYPTORHYNCHINAE}

Decilaus nigrohumeralis Lea

Decilaus nigrohumeralis Lea, 1930. Records of the South Australian Museum 4(2): 249.

Decilaus nigrohumeralis Lea. Hawkins, 1943. Annals and Magazine of Natural History, London (11)9(60): 890.

Decilaus nigrohumeralis Lea. Zimmerman, 1992. Australian Weevils 6: 226, pl. 417, figs. 1, 2.

Eutyrrhinus meditabundus (Fabricius)

Eutyrrhinus meditabundus (Fabricius). Olliff, 1888a. Proceedings of the Linnean Society of New South Wales (2)2(4): 1008 .

Eutyrrhinus meditabundus (Fabricius). Hawkins, 1943. Annals and Magazine of Natural History, London (11)9(60): 890 .

Eutyrrhinus meditabundus (Fabricius). Zimmerman, 1992. Australian Weevils 6: 252, pl. 430, figs. 5, 6.

\section{Mitrastethus lateralis Lea}

Mitrastethus lateralis Lea, 1931. Transactions and Proceedings of the Royal Society of South Australia 55: 64.

Mitrastethus lateralis Lea. Hawkins, 1943. Annals and Magazine of Natural History, London (11)9(60): 890.

Mitrastethus lateralis Lea. Zimmerman, 1992. Australian Weevils 2: 276, pl. 442, figs. 1, 2.

\section{Psepholax pascoei Olliff}

Psepholax pascoei Olliff, 1888a. Proceedings of the Linnean Society of New South Wales (2)2(4): 1008.

Psepholax pascoei Olliff. Hawkins, 1943. Annals and Magazine of Natural History, London (11)9(60): 890.

Sympiezoscelus norfolcensis Lea

Sympiezoscelus norfolcensis Lea, 1913. Transactions and Proceedings of the Royal Society of South Australia 37: 432.

Sympiezoscelus norfolcensis Lea. (Possibly a variety of S. spencei Waterhouse). Lea, 1913. Transactions and Proceedings of the Royal Society of South Australia 37: 433.

Sympiezoscelus norfolcensis Lea. Hawkins, 1943. Annals and Magazine of Natural History, London (11)9(60): 890.

Tapinocis setosus Lea

Tapinocis setosus Lea, 1928a. Transactions and Proceedings of the Royal Society of South Australia 52: 152.

Tapinocis setosus Lea. Hawkins, 1943. Annals and Magazine of Natural History, London (11)9(60): 890.

Tyrtaeosus imitator Lea

Tyrtaeosus imitator var. norfolcensis Lea, 1913. Transactions and Proceedings of the Royal Society of South Australia 37: 338.

Tyrtaeosus imitator var. norfolcensis Lea. Hawkins, 1943. Annals and Magazine of Natural History, London (11)9(60): 890.

Tyrtaeosus imitator Lea. Zimmerman, 1994a. Australian Weevils 1: 382, pl. 495, figs. 5, 6.

Calpurnius castaneus (Lea)

Xestocis castaneus Lea, 1913. Transactions and Proceedings of the Royal Society of South Australia 37: 435.

Xestocis castaneus Lea. Hawkins, 1943. Annals and Magazine of Natural History, London (11)9(60): 890.

Calpurnius castaneus (Lea). Zimmerman, 1994a. Australian Weevils 1: 648.

\section{COSSONINAE}

Xynotrupis insularis (Lea)

Notiosomus insularis Lea. 1927. Proceedings of the Linnean Society of New South Wales 52(3): 375.

Notiosomus insularis Lea. Hawkins, 1943. Annals and Magazine of Natural History, London (11)9(60): 891.

Xynotrupis insularis (Lea). Zimmerman, 1994a. Australian Weevils 1: 643.

\section{SCOLYTINAE}

Pachycotes kuscheli Schedl

Pachycotes kuscheli Schedl, 1972. New Zealand Journal of Science 15(3): 266, 267.

Pachycotes kuscheli Schedl. Holloway, 1977a. Lepidoptera of Norfolk Island, p. 271.

Pachycotes peregrinus (Chapius)

Pachycotes peregrinus (Chapius). Hawkins, 1943. Annals and Magazine of Natural History, London (11)9(60): 891.

\section{PLATYPODINAE}

Platypus norfolkensis Schedl

Platypus norfolkensis Schedl, 1972. New Zealand Journal of Science 15(3): 266, 272.

Platypus norfolkensis Schedl. Holloway, 1977a. Lepidoptera of Norfolk Island, p. 271.

Note: The following genera, not assigned to subfamilies, 
are arranged alphabetically pending clarification of their systematic position in remaining volumes of Zimmerman's Australian Weevils.

Mandalotus (Mandalotus) norfolcensis Lea

Mandalotus norfolcensis Lea, 1926b. Records of the South Australian Museum 3(2): 192.

Mandalotus norfolcensis Lea. Hawkins, 1943. Annals and Magazine of Natural History, London (11)9(60): 889.

Mandalotus norfolcensis Lea. Turner, Smithers \& Hoogland, 1968. The Conservation of Norfolk Island, p. 40.

Mandalotus (Mandalotus) norfolcensis Lea. Zimmerman, 1991. Australian Weevils 5: 430, pl. 214, figs. 3, 4.

Microcryptorhynchus norfolcensis Lea

Microcryptorhynchus norfolcensis Lea, 1928b. Records of the South Australian Museum 4(1): 83.

Microcryptorhynchus norfolcensis Lea. Hawkins, 1943. Annals and Magazine of Natural History, London (11)9(60): 890 .

Microcryptorhynchus rufimanus Lea

Microcryptorhynchus rufimanus Lea, 1928b. Records of the South Australian Museum 4(1): 84.

Microcryptorhynchus rufimanus Lea. Hawkins, 1943. Annals and Magazine of Natural History, London (11)9(60): 890.

Microcryptorhynchus setosus Lea

Microcryptorhynchus setosus Lea, 1928b. Records of the South Australian Museum 4(1): 87.

Microcryptorhynchus setosus Lea. Hawkins, 1943. Annals and Magazine of Natural History, London (11)9(60): 890.

Ocynoma rhysa Olliff

Ocynoma rhysa Olliff, 1888a. Proceedings of the Linnean Society of New South Wales (2)2(4): 1007.

Ocynoma rhysa Olliff. Hawkins, 1943. Annals and Magazine of Natural History, London (11)9(60): 889.

Ocynoma rhysa Olliff. Turner, Smithers \& Hoogland, 1968. The Conservation of Norfolk Island, p. 40.

Pentarthrum millingtoni Olliff

Pentarthrum millingtoni Olliff, 1888a. Proceedings of the Linnean Society of New South Wales (2)2(4): 1009.

Pentarthrum millingtoni Olliff. Hawkins, 1943. Annals and Magazine of Natural History, London (11)9(60): 890.

Pentarthrum nepeanianum Olliff

Pentarthrum nepeanianum Olliff, 1888a. Proceedings of the Linnean Society of New South Wales (2)2(4): 1009.

Pentarthrum nepeanianum Olliff. Hawkins, 1943. Annals and Magazine of Natural History, London (11)9(60): 890.

Pentarthrum nepeanianum Olliff. Turner, Smithers \& Hoogland, 1968. The Conservation of Norfolk Island, p. 40.

Phloeophagosoma sp.

Phloeophagosoma sp. Hawkins, 1943. Annals and Magazine of Natural History, London (11)9(60): 890.

\section{SIPHONAPTERA}

\section{PULICOIDEA}

\section{PULICIDAE}

Ctenocephalides felis (Bouché)

Ctenocephalides felis (Bouché). Ferrar, Standfast \& Dyce, 1975. Journal of the Australian entomological Society 14: 11.
Ctenocephalides felis (Bouché). Holloway, 1977a. Lepidoptera of Norfolk Island, p. 272.

Pulex (Pulex) irritans Linnaeus

Pulex (Pulex) irritans Linnaeus. Calder, 1996. Zoological Catalogue of Australia 28: 160.

\section{DIPTERA}

\section{NEMATOCERA}

\section{TIPULOMORPHA}

\section{TIPULIDAE}

\section{LIMONIINAE}

Limonia (Dicranomyia) norfolcensis (Alexander)

Dicranomyia norfolcensis Alexander, 1922. Records of the South Australian Museum 2: 231.

Limonia (Dicranomyia) norfolcensis (Alexander). Oosterbroek, 1989. In: N.L. Evenhuis (ed.). Catalog of the Diptera of the Australasian and Oceanian Regions p. 71.

Limonia (Dicranomyia) subremota (Alexander)

Dicranomyia subremota Alexander, 1922. Records of the South Australian Museum 2: 229.

Limonia (Dicranomyia) subremota (Alexander). Oosterbroek, 1989. In: N.L. Evenhuis (ed.). Catalog of the Diptera of the Australasian and Oceanian Regions p. 72.

Limonia (Dicranomyia) spp.

Limonia (Dicranomyia) spp. Holloway, 1977a. Lepidoptera of Norfolk Island, p. 272.

Limonia (Discobola) sp.

Limonia (Discobola) sp. Holloway, 1977a. Lepidoptera of Norfolk Island, p. 272.

Limonia (Geranomyia) sp.

Limonia (Geranomyia) sp. Holloway, 1977a. Lepidoptera of Norfolk Island, p. 272.

Limonia (Libnotes) sp.

Limonia (Libnotes) sp. Holloway, 1977a. Lepidoptera of Norfolk Island, p. 272.

\section{CULICOMORPHA}

\section{CULICOIDEA}

\section{CULICIDAE}

\section{CULICINAE}

Aedes (Halaedes) australis (Erichson)

Aedes (Pseudoskusea) concolor Taylor, 1934. Publication of the School of public Health and tropical Medicine, University of Sydney 1: 19.

Aedes (Halaedes) australis (Erichson). Marks, 1972. News Bulletin of the entomological Society of Queensland 87: 11.

Aedes (Halaedes) australis (Erichson). Ferrar, Standfast \& Dyce, 1975. Journal of the Australian entomological Society 14: 8 .

Aedes (Halaedes) australis (Erichson). Evenhuis \& Gon III, 1989. In: N.L. Evenhuis (ed.). Catalog of the Diptera of the Australasian and Oceanian Regions p. 198. 
Aedes (Finlaya) antipodeus (Edwards)

Aedes (Ochlerotatus) sp. near antipodeus (Edwards). Marks, 1972. News Bulletin of the entomological Society of Queensland 87: 12.

Aedes (Ochlerotatus) sp. near antipodeus (Edwards). Ferrar, Standfast \& Dyce, 1975. Journal of the Australian entomological Society 14: 9.

Aedes (Finlaya) antipodeus (Edwards). Evenhuis \& Gon III, 1989. In: N.L. Evenhuis (ed.). Catalog of the Diptera of the Australasian and Oceanian Regions p. 196.

Culex (Culex) quinquefasciatus Say

Culex fatigans Wiedemann. Hawkins, 1943. Annals and Magazine of Natural History, London (11)9(60): 894.

Culex (Culex) fatigans Wiedemann. Marks, 1972. News Bulletin of the entomological Society of Queensland 87: 12.

Culex (Culex) fatigans Wiedemann. Ferrar, Standfast \& Dyce, 1975. Journal of the Australian entomological Society 14: 8 .

Culex (Culex) quinquefasciatus Say. Belkin, 1962. Mosquitoes of the South Pacific. 1: 18, 197.

Culex (Culex) quinquefasciatus Say. Evenhuis \& Gon III, 1989. In: N.L. Evenhuis (ed.). Catalog of the Diptera of the Australasian and Oceanian Regions p. 206.

Culex (Culex) sp.

Culex (Culex) sp. near pervigilans Bergroth. Marks, 1972. News Bulletin of the entomological Society of Queensland 87: 12.

Culex (Culex) sp. near pervigilans Bergroth. Ferrar, Standfast \& Dyce, 1975. Journal of the Australian entomological Society $14: 8$.

\section{CHIRONOMOIDEA}

\section{CERATOPOGONIDAE}

\section{FORCIPOMYIINAE}

Atrichopogon sp.

Atrichopogon sp. Ferrar, Standfast \& Dyce, 1975. Journal of the Australian entomological Society 14: 9.

Forcipomyia spp.

Forcipomyia spp. Ferrar, Standfast \& Dyce, 1975. Journal of the Australian entomological Society 14: 9.

\section{CERATOPOGONINAE}

Alluaudomyia spp.

Allandomyia spp. Ferrar, Standfast \& Dyce, 1975. Journal of the Australian entomological Society 14: 9. (Misspelling of Alluaudomyia Kieffer. A. Dyce, pers. comm.).

Bezzia sp.

Bezzia sp. Ferrar, Standfast \& Dyce, 1975. Journal of the Australian entomological Society 14: 9.

Culicoides sp.

Culicoides sp. Ferrar, Standfast \& Dyce, 1975. Journal of the Australian entomological Society 14: 9.

Monohelea sp.

Monohelea sp. Ferrar, Standfast \& Dyce, 1975. Journal of the Australian entomological Society 14: 9.

\section{DASYHELEINAE}

Dasyhelea spp.

Dasyhelea spp. Ferrar, Standfast \& Dyce, 1975. Journal of the Australian entomological Society 14: 9.

\section{SIMULIIDAE}

\section{SIMULIINAE}

Nevermannia norfolkense (Dumbleton)

Simulium ornatipes norfolkense Dumbleton, 1969. New Zealand Journal of Science 12: 220, fig. 12.

Simulium ornatipes norfolkense Dumbleton. Ferrar, Standfast \& Dyce, 1975. Journal of the Australian entomological Society 14: 9.

Simulium ornatipes norfolkense Dumbleton. Holloway, 1977a. Lepidoptera of Norfolk Island, p. 272.

Nevermannia norfolkense (Dumbleton). Crosskey, 1989. In: N.L. Evenhuis (ed.). Catalog of the Diptera of the Australasian and Oceanian Regions p. 225.

\section{BIBIONOMORPHA}

\section{SCATOPSIDAE}

\section{SCATOPSINAE}

Coboldia fuscipes (Meigen)

Coboldia fuscipes (Meigen). Cook, 1989. In: N.L. Evenhuis (ed.). Catalog of the Diptera of the Australasian and Oceanian Regions p. 185.

\section{BRACHYCERA}

\section{ORTHORRHAPHA}

\section{EMPIDOIDEA}

\section{DOLICHOPODIDAE}

\section{SCIAPODINAE}

Amblypsilopus careelensis Bickel

Amblypsilopus careelensis Bickel, 1994. Records of the Australian Museum, Supplement 21: 319, fig. 103b.

Austrosciapus connexus (Walker)

Amblypsilopus connexus (Walker). Bickel \& Dyte, 1989. In: N.L. Evenhuis (ed.). Catalog of the Diptera of the Australasian and Oceanian Regions p. 394.

Austrosciapus connexus (Walker). Bickel, 1994. Records of the Australian Museum, Supplement 21: 242, figs. 75c, $76,77 \mathrm{c}, 126 \mathrm{~b}$.

Parentia vulgaris Bickel

Parentia vulgaris Bickel, 1994. Records of the Australian Museum, Supplement 21: 127, figs. 35, 38f-38h, 122d.

\section{DOLICHOPODINAE}

\section{Thrypticus australis Bickel}

Thrypticus australis Bickel. Bickel \& Dyte, 1989. In: N.L. Evenhuis (ed.). Catalog of the Diptera of the Australasian and Oceanian Regions p. 404.

Thrypticus australis Bickel. Bickel, 1986. Records of the Australian Museum 38: 145.

\section{HYDROPHORINAE}

Cymatopus simplex Parent

Cymatopus simplex Parent. Bickel \& Dyte, 1989. In: N.L. Evenhuis (ed.). Catalog of the Diptera of the Australasian and Oceanian Regions p. 405. 


\section{RHAPHIINAE}

Rhaphium pudicum (Parent)

Rhaphium pudicum (Parent). Bickel \& Dyte, 1989. In: N.L. Evenhuis (ed.). Catalog of the Diptera of the Australasian and Oceanian Regions p. 407.

\section{CYCLORRHAPHA}

\section{SCHIZOPHORA \\ SCIOMYZOIDEA}

\section{SEPSIDAE}

\section{SEPSINAE}

Lasionemopoda hirsuta (de Meijere)

Lasionemopoda hirsuta (de Meijere). Zuska, 1989. In: N.L. Evenhuis (ed.). Catalog of the Diptera of the Australasian and Oceanian Regions p. 573.

Parapalaeosepsis plebeia (de Meijere)

Parapalaeosepsis plebeia (de Meijere). Ferrar, Standfast \& Dyce, 1975. Journal of the Australian entomological Society 14: 11 .

Sepsis dissimilis Brunetti

Sepsis albopunctata Lamb. Ferrar, Standfast \& Dyce, 1975. Journal of the Australian entomological Society 14: 11.

Sepsis dissimilis Brunetti. Zuska, 1989. In: N.L. Evenhuis (ed.). Catalog of the Diptera of the Australasian and Oceanian Regions p. 573.

\section{LAUXANIIDAE}

\section{HOMONEURINAE}

\section{Homoneura spp.}

Homoneura spp. Holloway, 1977a. Lepidoptera of Norfolk Island, p. 272.

\section{LAUXANIINAE}

Poecilohetaerus ravus Schneider \& McAlpine

Poecilohetaerus ravus Schneider \& McAlpine, 1979. Australian entomological Magazine 6(4): 70, fig. 2.

Poecilohetaerus ravus Schneider \& McAlpine. Evenhuis \& Okadame, 1989. In: N.L. Evenhuis (ed.). Catalog of the Diptera of the Australasian and Oceanian Regions p. 580.

Poecilohetaerus trivittatus Schneider \& McAlpine

Poecilohetaerus trivittatus Schneider \& McAlpine, 1979. Australian entomological Magazine 6(4): 69, fig. 1.

Poecilohetaerus trivittatus Schneider \& McAlpine. Evenhuis \& Okadame, 1989. In: N.L. Evenhuis (ed.). Catalog of the Diptera of the Australasian and Oceanian Regions p. 580.

\section{TEPHRITOIDEA}

\section{PLATYSTOMATIDAE}

\section{PLATYSTOMATINAE}

Pogonortalis hians Schneider \& McAlpine

Pogonortalis hians Schneider \& McAlpine, 1979. Australian entomological Magazine 6(4): 72, figs. 3, 4.

Pogonortalis hians Schneider \& McAlpine. Evenhuis, 1989a. In: N.L. Evenhuis (ed.). Catalog of the Diptera of the Australasian and Oceanian Regions p. 494.

\section{HELIOMYZOIDEA}

\section{SPHAEROCERIDAE}

COPROMYZINAE

Copromyza sp.

Copromyza sp. Ferrar, Standfast \& Dyce, 1975. Journal of the Australian entomological Society 14: 11.

\section{LIMOSININAE}

Leptocera sp.

Leptocera sp. Ferrar, Standfast \& Dyce, 1975. Journal of the Australian entomological Society 14: 11.

\section{OPOMYZOIDEA}

\section{AGROMYZIDAE}

\section{PHYTOMYZINAE}

Cerodontha (Cerodontha) australis Malloch

Cerodontha (Cerodontha) australis Malloch. Spencer, 1976. Transactions of the Royal Society of New Zealand 6: 166, figs. 16-19.

Cerodontha (Cerodontha) australis Malloch. Holloway, 1977a. Lepidoptera of Norfolk Island, p. 272.

Cerodontha (Cerodontha) australis Malloch. Spencer, 1989. In: N.L. Evenhuis (ed.). Catalog of the Diptera of the Australasian and Oceanian Regions p. 542.

\section{AGROMYZINAE}

Ophiomyia lantanae (Froggatt)

Ophiomyia lantanae (Froggatt). Holloway, 1977a. Lepidoptera of Norfolk Island, p. 272.

\section{EPHYDROIDEA}

\section{DROSOPHILIDAE}

\section{DROSOPHILINAE}

Drosophila (Drosophila) immigrans Sturtevant

Drosophila (Drosophila) immigrans Sturtevant. Bock, 1986. Australian Journal of Zoology 34(2): 306.

Drosophila (Drosophila) immigrans Sturtevant. Evenhuis \& Okada, 1989. In: N.L. Evenhuis (ed.). Catalog of the Diptera of the Australasian and Oceanian Regions p. 618.

Drosophila (Sophophora) ananassae Doleschall

Drosophila (Sophophora) ananassae Doleschall. Bock, 1986. Australian Journal of Zoology 34(2): 305.

Drosophila (Sophophora) ananassae Doleschall. Evenhuis \& Okada, 1989. In: N.L. Evenhuis (ed.). Catalog of the Diptera of the Australasian and Oceanian Regions p. 627.

Drosophila (Sophophora) simulans Sturtevant

Drosophila (Sophophora) simulans Sturtevant. Bock, 1986. Australian Journal of Zoology 34(2): 306.

Drosophila (Sophophora) simulans Sturtevant. Evenhuis \& Okada, 1989. In: N.L. Evenhuis (ed.). Catalog of the Diptera of the Australasian and Oceanian Regions p. 628.

Hirtodrosophila naumanni (Bock)

Drosophila (Hirtodrosophila) naumanni Bock. Bock, 1986. Australian Journal of Zoology 34(2): 308.

Drosophila (Hirtodrosophila) naumanni Bock. Evenhuis \& Okada, 1989. In: N.L. Evenhuis (ed.). Catalog of the Diptera of the Australasian and Oceanian Regions p. 624 
Mycodrosophila (Mycodrosophila) rosemaryae Bock

Mycodrosophila rosemaryae Bock, 1986. Australian Journal of Zoology 34(2): 311.

Mycodrosophila (Mycodrosophila) rosemaryae Bock. Evenhuis \& Okada, 1989. In: N.L. Evenhuis (ed.). Catalog of the Diptera of the Australasian and Oceanian Regions p. 631.

Scaptodrosophila enigma (Malloch)

Drosophila (Scaptodrosophila) enigma Malloch. Bock, 1986. Australian Journal of Zoology 34(2): 306.

Drosophila (Scaptodrosophila) enigma Malloch. Evenhuis \& Okada, 1989. In: N.L. Evenhuis (ed.). Catalog of the Diptera of the Australasian and Oceanian Regions p. 625.

Scaptodrosophila inornata (Malloch)

?Drosophila (Scaptodrosophila) inornata Malloch. Bock, 1986. Australian Journal of Zoology 34(2): 308.

Drosophila (Scaptodrosophila) inornata Malloch. Evenhuis \& Okada, 1989. In: N.L. Evenhuis (ed.). Catalog of the Diptera of the Australasian and Oceanian Regions p. 625.

Scaptodrosophila norfolkensis (Bock)

Drosophila (Scaptodrosophila) norfolkensis Bock, 1986. Australian Journal of Zoology 34(2): 306, figs. 1, 2.

Drosophila (Scaptodrosophila) norfolkensis Bock. Evenhuis \& Okada, 1989. In: N.L. Evenhuis (ed.). Catalog of the Diptera of the Australasian and Oceanian Regions p. 626.

Scaptomyza (Bunostoma) australis Malloch

Scaptomyza (Bunostoma) australis Malloch. Bock, 1986. Australian Journal of Zoology 34(2): 309.

Scaptomyza (Bunostoma) australis Malloch. Evenhuis \& Okada, 1989. In: N.L. Evenhuis (ed.). Catalog of the Diptera of the Australasian and Oceanian Regions p. 634.

Scaptomyza (Bunostoma) philipensis Bock

Scaptomyza (Bunostoma) philipensis Bock, 1986. Australian Journal of Zoology 34(2): 310, figs. 5, 6.

Scaptomyza (Bunostoma) philipensis Bock. Evenhuis \& Okada, 1989. In: N.L. Evenhuis (ed.). Catalog of the Diptera of the Australasian and Oceanian Regions p. 611.

\section{STEGANINAE}

Leucophenga pacifica Bock

Leucophenga pacifica Bock, 1986. Australian Journal of Zoology 34(2): 311.

Leucophenga pacifica Bock. Evenhuis \& Okada, 1989. In: N.L. Evenhuis (ed.). Catalog of the Diptera of the Australasian and Oceanian Regions p. 611.

\section{MUSCOIDEA}

\section{ANTHOMYIIDAE}

Delia urbana (Malloch)

Delia urbana (Malloch). Pont, 1973b. Journal of the Australian entomological Society 12: 177, 194.

Delia urbana (Malloch). Pont, 1989a. In: N.L. Evenhuis (ed.). Catalog of the Diptera of the Australasian and Oceanian Regions p. 674.

\section{FANNIIDAE}

\section{FANNIINAE}

\section{Euryomma peregrinum (Meigen)}

Euryomma peregrinum (Meigen). Pont, 1973b. Journal of the Australian entomological Society 12: 177, 182.
Euryomma peregrinum (Meigen). Ferrar, Standfast \& Dyce, 1975. Journal of the Australian entomological Society 14: 10 .

Euryomma peregrinum (Meigen). Pont, 1989c. In: N.L. Evenhuis (ed.). Catalog of the Diptera of the Australasian and Oceanian Regions p. 700.

\section{Fannia howei Pont}

Fannia howei Pont, 1977. Australian Journal of Zoology, Supplementary Series 51: 77.

Fannia howei Pont. Pont, 1989c. In: N.L. Evenhuis (ed.). Catalog of the Diptera of the Australasian and Oceanian Regions p. 700

Fannia norfolki Pont

Fannia norfolki Pont, 1977. Australian Journal of Zoology, Supplementary Series 51: 22.

Fannia norfolki Pont. Pont, 1989c. In: N.L. Evenhuis (ed.) Catalog of the Diptera of the Australasian and Oceanian Regions p. 701.

Fannia spp.

Fannia spp. Pont, 1973b. Journal of the Australian entomological Society 12: 177, 182, 183.

Fannia spp. Ferrar, Standfast \& Dyce, 1975. Journal of the Australian entomological Society 14: 10.

\section{MUSCIDAE}

\section{COENOSIINAE}

Coenosia spumicola Pont

Coenosia spumicola Pont, 1973b. Journal of the Australian entomological Society 12: 177, 179, figs. 1-5.

Coenosia spumicola Pont. Pont, 1989b. In: N.L. Evenhuis (ed.). Catalog of the Diptera of the Australasian and Oceanian Regions p. 695.

Lispe incerta Malloch

Lispe incerta Malloch. Pont, 1973b. Journal of the Australian entomological Society 12: 177, 189.

Lispe incerta Malloch. Pont, 1989b. In: N.L. Evenhuis (ed.). Catalog of the Diptera of the Australasian and Oceanian Regions p. 693.

Pygophora maculigera (Stein)

Pygophora maculigera (Stein). Pont, 1973b. Journal of the Australian entomological Society 12: 177, 191.

Pygophora maculigera (Stein). Pont, 1989b. In: N.L. Evenhuis (ed.). Catalog of the Diptera of the Australasian and Oceanian Regions p. 698.

Spilogona ferrari Pont

Spilogona ferrari Pont, 1973b. Journal of the Australian entomological Society 12: 177, 191, figs. 15-18.

Spilogona ferrari Pont. Pont, 1989b. In: N.L. Evenhuis (ed.). Catalog of the Diptera of the Australasian and Oceanian Regions p. 694.

\section{MUSCINAE}

Hydrotaea rostrata (Robineau-Desvoidy)

Australophyra rostrata (Robineau-Desvoidy). Pont, 1973b. Journal of the Australian entomological Society 12: 176, 179.

Australophyra rostrata (Robineau-Desvoidy). Pont, 1973a. Australian Journal of Zoology, Supplementary Series 12: 250, figs. 119, 121, 125, 129, 133, 140, 141, 167.

Australophyra rostrata (Robineau-Desvoidy). Ferrar, Standfast \& Dyce, 1975. Journal of the Australian entomological Society 14: 9. 
Hydrotaea rostrata (Robineau-Desvoidy). Pont, 1989b. In: N.L. Evenhuis (ed.). Catalog of the Diptera of the Australasian and Oceanian Regions p. 677.

Musca domestica Linnaeus

Musca domestica Linnaeus. Pont, 1973b. Journal of the Australian entomological Society 12: 177, 189.

Musca domestica Linnaeus. Pont, 1973a. Australian Journal of Zoology, Supplementary Series 21: 175, figs. 25, 30, $35,40,45,59,60$.

Musca domestica Linnaeus. Ferrar, Standfast \& Dyce, 1975. Journal of the Australian entomological Society 14: 9.

Muscina stabulans (Fallén)

Muscina stabulans (Fallén). Pont, 1973b. Journal of the Australian entomological Society 12: 177, 190.

Muscina stabulans (Fallén). Pont, 1989b. In: N.L. Evenhuis (ed.). Catalog of the Diptera of the Australasian and Oceanian Regions p. 676.

Stomoxys calcitrans (Linnaeus)

Stomoxys calcitrans (Linnaeus). Pont, 1973b. Journal of the Australian entomological Society 12: 177, 193.

Stomoxys calcitrans (Linnaeus). Pont, 1973a. Australian Journal of Zoology, Supplementary Series 21: 262, figs. 142, 145-149, 155, 156, 170.

Stomoxys calcitrans (Linnaeus). Ferrar, Standfast \& Dyce, 1975. Journal of the Australian entomological Society 14: 9, 11.

Synthesiomyia nudiseta Wulp

Synthesiomyia nudiseta Wulp. Pont, 1973b.Journal of the Australian entomological Society 12: 177, 194.

Synthesiomyia nudiseta Wulp. Ferrar, Standfast \& Dyce, 1975. Journal of the Australian entomological Society 14: 10.

Synthesiomyia nudiseta Wulp. Pont, 1989b. In: N.L. Evenhuis (ed.). Catalog of the Diptera of the Australasian and Oceanian Regions p. 676.

\section{PHAONIINAE}

Atherigona bidens Hennig

Atherigona sp. Pont, 1973b. Journal of the Australian entomological Society 12: 176, 179.

Atherigona bidens Hennig. Holloway, 1977a. Lepidoptera of Norfolk Island, p. 272.

Atherigona bidens Hennig. Pont, 1989b. In: N.L. Evenhuis (ed.). Catalog of the Diptera of the Australasian and Oceanian Regions p. 681.

Atherigona tibiseta Malloch

Atherigona tibiseta Malloch. Pont, 1973b. Journal of the Australian entomological Society 12: 176, 178.

Atherigona tibiseta Malloch. Pont, 1989b. In: N.L. Evenhuis (ed.). Catalog of the Diptera of the Australasian and Oceanian Regions p. 682.

\section{Helina regina Malloch}

Helina regina Malloch. Pont, 1973b. Journal of the Australian entomological Society 12: 177, 188.

Helina regina Malloch. Pont, 1989b. In: N.L. Evenhuis (ed.). Catalog of the Diptera of the Australasian and Oceanian Regions p. 686.

Helina sp.

Helina sp. Pont, 1973b. Journal of the Australian entomological Society 12: 177, 188.

\section{CALLIPHORIDAE}

\section{CHRYSOMYINAE}

Chrysomyia varipes (Macquart)

Chrysomyia varipes (Macquart). Ferrar, Standfast \& Dyce, 1975. Journal of the Australian entomological Society 14: 10 .

Chrysomyia varipes (Macquart). Kurahashi, 1989. In: N.L. Evenhuis (ed.). Catalog of the Diptera of the Australasian and Oceanian Regions p. 713.

\section{CALLIPHORINAE}

Calliphora (Paracalliphora) norfolka Kurahashi

Calliphora (Paracalliphora) norfolka Kurahashi, 1971. Pacific Insects 13: 174, figs. 70-73.

Calliphora norfolka Kurahashi. Ferrar, Standfast \& Dyce, 1975. Journal of the Australian entomological Society 14: 10.

Calliphora norfolka Kurahashi. Holloway, 1977a. Lepidoptera of Norfolk Island, p. 272.

Calliphora (Paracalliphora) norfolka Kurahashi. Kurahashi, 1989. In: N.L. Evenhuis (ed.). Catalog of the Diptera of the Australasian and Oceanian Regions p. 705.

\section{Calliphora sp.}

Calliphora sp. Ferrar, Standfast \& Dyce, 1975. Journal of the Australian entomological Society 14: 10.

Calliphora (Neocalliphora) stygia (Fabricius)

Calliphora stygia (Fabricius). Ferrar, Standfast \& Dyce, 1975. Journal of the Australian entomological Society 14: 10.

Calliphora (Neocalliphora) stygia (Fabricius). Kurahashi, 1989. In: N.L. Evenhuis (ed.). Catalog of the Diptera of the Australasian and Oceanian Regions p. 704.

Lucilia sericata (Meigen)

Lucilia sericata (Meigen). Ferrar, Standfast \& Dyce, 1975. Journal of the Australian entomological Society 14: 10.

Lucilia sericata (Meigen). Kurahashi, 1989. In: N.L. Evenhuis (ed.). Catalog of the Diptera of the Australasian and Oceanian Regions p. 711.

\section{SARCOPHAGIDAE}

\section{SARCOPHAGINAE}

Boettherisca peregrina (Robineau-Desvoidy)

Boettherisca peregrina (Robineau-Desvoidy). Ferrar, Standfast \& Dyce, 1975. Journal of the Australian entomological Society 14: 10.

Boettherisca peregrina (Robineau-Desvoidy). Lopes, 1989. In: N.L. Evenhuis (ed.). Catalog of the Diptera of the Australasian and Oceanian Regions p. 725.

Hybopygia varia (Walker)

Hybopygia varia (Walker). Ferrar, Standfast \& Dyce, 1975. Journal of the Australian entomological Society 14: 10.

Hybopygia varia (Walker). Lopes, 1989. In: N.L. Evenhuis (ed.). Catalog of the Diptera of the Australasian and Oceanian Regions p. 724.

Sarcorohdendorfia epsilon (Johnston and Tiegs)

Sarcorohdendorfia epsilon (Johnston and Tiegs). Ferrar, Standfast \& Dyce, 1975. Journal of the Australian entomological Society 14: 10.

Sarcorohdendorfia epsilon (Johnston and Tiegs). Lopes, 1989. In: N.L. Evenhuis (ed.). Catalog of the Diptera of the Australasian and Oceanian Regions p. 729. 


\section{GASTEROPHILIDAE}

Gasterophilus intestinalis De Geer

Gasterophilus intestinalis De Geer. Ferrar, Standfast \& Dyce, 1975. Journal of the Australian entomological Society 14: 9.

Gasterophilus intestinalis De Geer. Evenhuis, 1989b. In: N.L. Evenhuis (ed.). Catalog of the Diptera of the Australasian and Oceanian Regions p. 720.

\section{TRICHOPTERA}

\section{LIMNEPHILOIDEA}

\section{LEPTOCERIDAE}

\section{Triplectides australis Navas}

!Notanatolica magna Walker. Tillyard, 1917. Proceedings of the Linnean Society of New South Wales 42: 544.

!Triplectides cephalotes (Walker). Hawkins, 1943. Annals and Magazine of Natural History, London (11)9(60): 879.

!Triplectides cephalotes (Walker). Mosely \& Kimmins, 1953. The Trichoptera (Caddis-Flies) of Australia and New Zealand p. 204, 205, fig. 137.

!Triplectides cephalotes (Walker). Holloway, 1977a. Lepidoptera of Norfolk Island, p. 273.

Triplectides australis Navas. Morse \& Neboiss, 1982. Memoirs of the national Museum of Victoria 43: 64.

\section{LEPIDOPTERA}

\section{GLOSSATA}

\section{TINEOIDEA}

\section{TINEIDAE}

\section{SCARDIINAE}

Morophaga clonodes (Meyrick)

Morophaga clonodes (Meyrick). Holloway, 1982. Journal of Natural History 16(3): 357.

\section{TINEINAE}

Monopis crocicapitella (Clemens)

Monopis crocicapitella (Clemens). Holloway, 1977a. Lepidoptera of Norfolk Island, p. 275.

Monopis meliorella (Walker)

!Monopis vivipara Scott. Hawkins, 1943. Annals and Magazine of Natural History, London (11)9(60): 874. (= meliorella Walker).

Monopis meliorella (Walker). Holloway, 1977a. Lepidoptera of Norfolk Island, p. 275.

Monopis meliorella (Walker). Bradley, 1982. Journal of Natural History 16(3): 369.

Monopis nigroleuca Bradley

Monopis sp. Holloway, 1977a. Lepidoptera of Norfolk Island, p. 275.

Monopis nigroleuca Bradley, 1982. Journal of Natural History 16(3): 367, figs. 1, 14-16.

Thomintarra cortella (Walker)

Trithamnora cortella (Walker). Holloway, 1977a. Lepidoptera of Norfolk Island, p. 275.
Tinea sp.

Tinea sp. Turner, 1917. Transactions and Proceedings of the Royal Society of South Australia 41: 56.

Tinea sp. Turner, 1918. Transactions and Proceedings of the Royal Society of South Australia 42: 284.

Tinea sp. Hawkins, 1943. Annals and Magazine of Natural History, London (11)9(60): 874.

Tinea sp. Turner, Smithers \& Hoogland, 1968. The Conservation of Norfolk Island, p. 40.

\section{SETOMORPHINAE}

Lindera tessellatella Blanchard

Setomorpha tessellatella (Blanchard). Holloway, 1977a. Lepidoptera of Norfolk Island, p. 275.

\section{HIEROXESTINAE}

Opogona omoscopa (Meyrick)

Hieroxestis omoscopa Meyrick. Turner, 1917. Transactions and Proceedings of the Royal Society of South Australia 41: 56.

Hieroxestis omoscopa Meyrick. Turner, 1918. Transactions and Proceedings of the Royal Society of South Australia 42: 288

Opogona omoscopa (Meyrick). Hawkins, 1943. Annals and Magazine of Natural History, London (11)9(60): 867, 874.

Opogona omoscopa (Meyrick). Bradley, 1956. Bulletin of the British Museum of Natural History (Entomology) 4: 160 .

Opogona omoscopa (Meyrick). Holloway, 1977a. Lepidoptera of Norfolk Island, p. 275.

Opogona psola Bradley

Opogona psola Bradley, 1956. Bulletin of the British Museum of Natural History (Entomology) 4: 160, figs. $13,19,20$.

Opogona psola Bradley. Turner, Smithers \& Hoogland, 1968. The Conservation of Norfolk Island, p. 40.

Opogona psola Bradley. Holloway, 1977a. Lepidoptera of Norfolk Island, p. 275.

\section{ERECHTHIINAE}

Comodica semiades Bradley

Comodica semiades Bradley, 1956. Bulletin of the British Museum of Natural History (Entomology) 4: 159, figs. $11,17,18$.

Comodica semiades Bradley. Turner, Smithers \& Hoogland, 1968. The Conservation of Norfolk Island, p. 40.

Comodica semiades Bradley. Holloway, 1977a. Lepidoptera of Norfolk Island, p. 275.

Erechthias capnitis (Turner)

Tinea capnitis Turner, 1918. Transactions and Proceedings of the Royal Society of South Australia 42: 288.

Tinea capnitis Turner. Hawkins, 1943. Annals and Magazine of Natural History, London (11)9(60): 874.

Empaesta capnitis (Turner). Bradley, 1956. Bulletin of the British Museum of Natural History (Entomology) 4: 164, figs. 22-24.

Tinea capnitis Turner. Turner, Smithers \& Hoogland, 1968. The Conservation of Norfolk Island, p. 40.

Empaesta capnitis (Turner). Holloway, 1977a. Lepidoptera of Norfolk Island, p. 275.

Empaesta capnitis (Turner). Holloway, 1982. Journal of Natural History 16(3): 357. 
Erechthias strigata Bradley

Erechthias strigata Bradley, 1956. Bulletin of the British Museum of Natural History (Entomology) 4: 158, figs. $15,16$.

Erechthias strigata Bradley. Turner, Smithers, and Hoogland, 1968. The Conservation of Norfolk Island, p. 40.

Erechthias strigata Bradley. Holloway, 1977a. Lepidoptera of Norfolk Island, p. 275.

\section{HAPSIFERINAE}

Parochmastis hilderi (Bradley)

Norfolkia hilderi Bradley, 1956. Bulletin of the British Museum of Natural History (Entomology) 4: 162, figs. 12, 25, 26.

Norfolkia hilderi Bradley. Turner, Smithers \& Hoogland, 1968. The Conservation of Norfolk Island, p. 40.

Eunorfolkia hilderi (Bradley). Holloway, 1977a. Lepidoptera of Norfolk Island, p. 275.

Tineid sp. Holloway, 1977a. Lepidoptera of Norfolk Island, p. 275.

\section{GRACILLARIIDAE}

\section{GRACILLARIINAE}

\section{Acrocercops sp.}

Acrocercops sp. Holloway, 1977a. Lepidoptera of Norfolk Island, p. 276.

\section{LITHOCOLLETINAE}

Phyllonorycter messaniella (Zeller)

Phyllonorycter messaniella (Zeller). Smithers, 1977. Australian entomological Magazine 4(1): 16.

Phyllonorycter messaniella (Zeller). Holloway, 1982. Journal of Natural History 16(3): 357.

\section{YPONOMEUTOIDEA}

\section{YPONOMEUTIDAE}

\section{YPONOMEUTINAE}

Thecobathria dilechria Bradley

Thecobathria dilechria Bradley, 1982. Journal of Natural History 16: 371, figs. 4-6, 21-23.

\section{PRAYDINAE}

Prays nephelomina (Meyrick)

Prays nephelomina (Meyrick). Holloway, 1977a. Lepidoptera of Norfolk Island, p. 276.

Yponomeutid sp. Holloway, 1977a. Lepidoptera of Norfolk Island, p. 276.

\section{PLUTELLIDAE}

\section{PLUTELLINAE}

Orthenches celetrica Bradley

Orthenches celetrica Bradley, 1982. Journal of Natural History 16: 369, figs. 2, 3, 17-20.

Plutella xylostella (Linnaeus)

Plutella maculipennis (Curtis). Hawkins, 1943. Annals and Magazine of Natural History, London (11)9(60): 874.

Plutella xylostella (Linnaeus). Holloway, 1977a. Lepidoptera of Norfolk Island, p. 276.

\section{LYONETIIDAE}

\section{BEDELLIINAE}

Bedellia somnulentella (Zeller)

Bedellia somnulentella (Zeller). Holloway, 1977a. Lepidoptera of Norfolk Island, p. 275.

\section{GELECHIOIDEA}

\section{OECOPHORIDAE}

\section{OECOPHORINAE}

Hofmannophila pseudospretella (Stainton)

Hofmannophila pseudospretella (Stainton). Holloway, 1977a. Lepidoptera of Norfolk Island, p. 277.

\section{STATHMOPODINAE}

Pachyrhabda sp.

Pachyrhabda sp. Holloway, 1977a. Lepidoptera of Norfolk Island, p. 276.

Stathmopoda sp.

Stathmopoda sp. Holloway, 1977a. Lepidoptera of Norfolk Island, p. 276.

\section{ELACHISTIDAE}

\section{ELACHISTINAE}

?Cosmiotes aphanta Turner

?Elachista archaeonoma Meyrick. Hawkins, 1943. Annals and Magazine of Natural History, London (11)9(60): 874.

?Cosmiotes aphanta Turner. Holloway, 1977a. Lepidoptera of Norfolk Island, p. 276.

\section{BLASTOBASIDAE}

Blastobasis sp.

Blastobasis sp. Holloway, 1977a. Lepidoptera of Norfolk Island, p. 277.

\section{COSMOPTERIGIDAE}

\section{COSMOPTERIGINAE}

Cosmopterix attenuatella (Walker)

?Cosmopterix mimetis Meyrick. Hawkins, 1943. Annals and Magazine of Natural History, London (11)9(60): 874.

?Cosmopterix mimetis Meyrick. Turner, Smithers \& Hoogland, 1968. The Conservation of Norfolk Island. P. 40.

Cosmopterix attenuatella (Walker). Holloway, 1982. Journal of Natural History 16(3): 357. (= mimetis Meyrick).

Pyroderces anoista Bradley

?Pyroderces anoista Bradley. Holloway, 1977a. Lepidoptera of Norfolk Island, p. 277.

\section{MOMPHIDAE}

Zapyrastra calliphana Meyrick

Zapyrasta calliphana Meyrick. Holloway, 1977a. Lepidoptera of Norfolk Island, p. 277. [Zapyrasta is a misspelling].

\section{GELECHIIDAE}

\section{CHELARIINAE}

Anarsia lechriosema Bradley

Anarsia sp. Holloway, 1977a. Lepidoptera of Norfolk Island, p. 277. 
Anarsia lechriosema Bradley, 1982. Journal of Natural History 16: 375, figs. 9-11, 27, 28.

Anarsia trichodeta Meyrick

Anarsia trichodeta Meyrick. Bradley, 1982. Journal of Natural History 16(3): 377.

Anisoplaca cosmia Bradley

Anisoplaca cosmia Bradley, 1956. Bulletin of the British Museum of Natural History (Entomology) 4: 156, figs. $14,21$.

Anisoplaca cosmia Bradley. Turner, Smithers \& Hoogland, 1968. The Conservation of Norfolk Island, p. 40.

Anisoplaca cosmia Bradley. Holloway, 1977a. Lepidoptera of Norfolk Island, p. 277.

Pectinophora scutigera (Holdaway)

Pectinophora scutigera (Holdaway). Holloway, 1977a. Lepidoptera of Norfolk Island, p. 277.

\section{BRACHMIINAE}

Brachmia sp. [near arotraea (Meyrick)]

Brachmia sp. near arotraea (Meyrick). Turner, 1918. Transactions and Proceedings of the Royal Society of South Australia 42: 284, 288.

Brachmia sp. near arotraea (Meyrick). Hawkins, 1943. Annals and Magazine of Natural History, London (11)9(60): 873.

Brachmia sp. near arotraea (Meyrick). Turner, Smithers \& Hoogland, 1968. The Conservation of Norfolk Island, p. 40.

Brachmia sp. near arotraea (Meyrick). Holloway, 1977a. Lepidoptera of Norfolk Island, p. 277.

\section{DICHROMERIDINAE}

\section{Dichomeris ianthes (Meyrick)}

Dichomeris ianthes (Meyrick). Holloway, 1977a. Lepidoptera of Norfolk Island, p. 277.

\section{GELECHIINAE}

\section{Phthorimaea operculella (Zeller)}

Phthorimaea operculella (Zeller). Holloway, 1977a. Lepidoptera of Norfolk Island, p. 277.

\section{ANACAMPSINAE}

Aproaerema simplexella (Walker)

Stomopteryx simplexella (Walker). Holloway, 1977a. Lepidoptera of Norfolk Island, p. 277.

Gelechiid sp. Holloway, 1977a. Lepidoptera of Norfolk Island, p. 277.

\section{LECITHOCERIDAE}

Lecithocera sp.

Lecithocera sp. Holloway, 1977a. Lepidoptera of Norfolk Island, p. 277.

\section{TORTRICOIDEA}

\section{TORTRICIDAE}

\section{TORTRICINAE}

Capua intractana (Walker)

Capua intractana (Walker). Holloway, 1977a. Lepidoptera of Norfolk Island, p. 273.
Diactenis veligera Meyrick

Diactenis veligera Meyrick. Holloway, 1977a. Lepidoptera of Norfolk Island, p. 273.

Eupoecilia sp.

?Aethes sp. Holloway, 1977a. Lepidoptera of Norfolk Island, p. 275.

Eupoecilia sp. Holloway, 1982. Journal of Natural History 16(3): 357.

?Merophyas divulsana (Walker)

Tortrix sp. near divulsana Walker. Turner. 1917. Transactions and Proceedings of the Royal Society of South Australia 41: 56.

?Merophyas divulsana (Walker). Holloway, 1977a. Lepidoptera of Norfolk Island, p. 273.

\section{Schoenotenes capnosema Turner}

Schoenotenes capnosema Turner, 1917. Transactions and Proceedings of the Royal Society of South Australia 41: 56.

Schoenotenes capnosema Turner. Turner, 1918. Transactions and Proceedings of the Royal Society of South Australia 42: 287.

Schoenotenes capnosema Turner. Hawkins, 1943. Annals and Magazine of Natural History, London (11)9(60): 873.

Schoenotenes capnosema Turner. Bradley, 1956. Bulletin of the British Museum (Natural History) (Entomology) 4: 154, fig. 10.

Schoenotenes capnosema Turner. Turner, Smithers \& Hoogland. 1968. The Conservation of Norfolk Island, p. 40.

Schoenotenes capnosema Turner. Holloway, 1977a. Lepidoptera of Norfolk Island, p. 274.

Trincophora aridela (Turner)

Capua sp. Turner, 1917. Transactions and Proceedings of the Royal Society of South Australia 41: 56.

Capua aridela Turner. Turner, 1918. Transactions and Proceedings of the Royal Society of South Australia 42: 286.

Capua aridella [sic] Hawkins, 1943. Annals and Magazine of Natural History, London (11)9(60): 873 (specific name misspelt).

Trincophora aridela (Turner). (= ?T. canana [Walker]). Holloway, 1977a. Lepidoptera of Norfolk Island, p. 273.

Tortrix sp.

Tortrix sp. Turner, 1918. Transactions and Proceedings of the Royal Society of South Australia 42: 287.

Tortrix sp. Hawkins, 1943. Annals and Magazine of Natural History, London (11)9(60): 873.

Tortrix sp. Turner, Smithers \& Hoogland, 1968. The Conservation of Norfolk Island, p. 40.

Tracholena hedraea Common

Tracholena hedraea Common, 1982. Journal of the Australian entomological Society 21: 223, figs. 1, 3, 4, 8-10.

\section{CHLIDANOTINAE}

Trymalitis cataracta Meyrick

Trymalitis cataracta Meyrick, Holloway, 1977a. Lepidoptera of Norfolk Island, p. 274.

\section{OLETHREUTINAE}

Acroclita macroma Turner

Acroclita sp. Turner, 1917. Transactions and Proceedings of the Royal Society of South Australia 41: 56. 
Acroclita macroma Turner. Turner, 1918. Transactions and Proceedings of the Royal Society of South Australia 42: 287.

Acroclita macroma Turner. Hawkins, 1943. Annals and Magazine of Natural History, London (11)9(60): 873.

Acroclita macroma Turner. Holloway, 1977a. Lepidoptera of Norfolk Island, p. 274.

Acroclita sp.

Acroclita sp. (near bryopa Meyrick). Holloway, 1977a. Lepidoptera of Norfolk Island, p. 274.

Acroclita sp.

Acroclita sp. (not macroma). Holloway, 1977a. Lepidoptera of Norfolk Island, p. 282.

Bactra blepharopis Meyrick

Bactra sp. Holloway, 1977a. Lepidoptera of Norfolk Island, p. 274.

Bactra blepharopis Meyrick. Holloway, 1982. Journal of Natural History 16(3): 357.

Bactra optanias Meyrick

Bactra optanias Meyrick. Holloway, 1982. Journal of Natural History 16(3): 357.

Bactra testudinea Turner

Bactra testudinea Turner. Holloway, 1977a. Lepidoptera of Norfolk Island, p. 274.

\section{Crocidosema plebeiana Zeller}

Eucosmia plebeiana (Zeller). Turner, 1917. Transactions and Proceedings of the Royal Society of South Australia 41: 56.

Eucosmia plebeiana (Zeller). Turner, 1918. Transactions and Proceedings of the Royal Society of South Australia 42: 288.

Crocidosema plebeiana Zeller. Hawkins, 1943. Annals and Magazine of Natural History, London (11)9(60): 867, 873.

Crocidosema plebejana [sic] Zeller. Holloway, 1977a. Lepidoptera of Norfolk Island, p. 274.

Cryptaspasma pullatana Bradley

Cryptaspasma (Allobrachygonia) sp. near querula Meyrick. Holloway, 1977a. Lepidoptera of Norfolk Island, p. 274.

Cryptaspasma pullatana Bradley, 1982. Journal of Natural History 16(3): 377, figs. 12, 13, 29, 30.

Cryptophlebia encarpa (Meyrick)

Argyroploce illepida Butler. Turner, 1917. Transactions and Proceedings of the Royal Society of South Australia 41: 46.

Argyroploce illepida Butler. Turner, 1918. Transactions and Proceedings of the Royal Society of South Australia 42: 288.

Argyroploce illepida Butler. Hawkins, 1943. Annals and Magazine of Natural History, London (11)9(60): 873.

Crytpophlebia encarpa (Meyrick). Holloway, 1977a. Lepidoptera of Norfolk Island, p. 274.

Cryptophlebia ombrodelta (Lower)

Crytpophlebia ombrodelta (Lower). Holloway, 1977a. Lepidoptera of Norfolk Island, p. 274.

Cydia pomonella (Linnaeus)

Cydia pomonella (Linnaeus). Holloway, 1977a. Lepidoptera of Norfolk Island, p. 274.

Epinotia lantana (Busck)

Epinotia lantana (Busck). Holloway, 1977a. Lepidoptera of Norfolk Island, p. 274.
Lobesia aeolopa Meyrick

Lobesia aeolopa Meyrick. Holloway, 1977a. Lepidoptera of Norfolk Island, p. 274.

Lobesia parvulana (Walker)

Polychrosis botrana (Schiffermuller). Turner, 1917. Transactions and Proceedings of the Royal Society of South Australia 41: 56.

Polychrosis botrana (Schiffermuller). Turner, 1918. Transactions and Proceedings of the Royal Society of South Australia 42: 288.

Polychrosis botrana (Schiffermuller). Hawkins, 1943. Annals and Magazine of Natural History, London (11)9(60): 873.

Polychrosis botrana (Schiffermuller). Holloway, 1977a. Lepidoptera of Norfolk Island, p. 274.

Spilonota macropetana (Meyrick)

Spilonota macropetana (Meyrick). Holloway, 1977a. Lepidoptera of Norfolk Island, p. 274.

Spilonota scopulosana (Meyrick)

Spilonota scopulosana (Meyrick). Holloway, 1977a. Lepidoptera of Norfolk Island, p. 274.

Spilonota sp.

Spilonota sp. Holloway, 1977a. Lepidoptera of Norfolk Island, p. 274.

Tortricid sp. Holloway, 1977a. Lepidoptera of Norfolk Island, p. 282.

\section{SESIOIDEA}

\section{CHOREUTIDAE}

\section{CHOREUTINAE}

Tebenna bradleyi Clarke

Tebenna bradleyi Clarke. Holloway, 1977a. Lepidoptera of Norfolk Island, p. 276.

\section{IMMOIDEA}

\section{IMMIDAE}

Imma celtiphaga Bradley.

Imma celtiphaga Bradley, 1982. Journal of Natural History 16: 373, figs. $7,8,24-26$.

Imma $\mathrm{sp}$

Imma sp. Holloway, 1977a. Lepidoptera of Norfolk Island, p. 276.

\section{COPROMORPHOIDEA}

\section{CARPOSINIDAE}

Coscinoptycha improbana Meyrick

Coscinoptycha improbana Meyrick. Holloway, 1977a. Lepidoptera of Norfolk Island, p. 278.

Coscinoptycha improbana Meyrick. Common, 1990. Moths of Australia p. 318, fig. 30.1. 


\section{EPERMENIOIDEA}

\section{EPERMENIIDAE}

\section{EPERMENIINAE}

Epermenia (Calotripis) insularis Gaedike

Epermenia (Calotripis) insularis Gaedike, 1979. Beiträge zur Entomologie, Berlin 29: 277, figs. 1-5.

Epermenia insularis Gaedike. Holloway, 1984. Proceedings and Transactions of the British entomological and natural History Society 17(3): 68.

Epermenia sp.

Epermenia sp. Holloway, 1977a. Lepidoptera of Norfolk Island, p. 276.

\section{PTEROPHOROIDEA}

\section{PTEROPHORIDAE}

\section{Platyptilia sp.}

Platyptilia sp. Holloway, 1977a. Lepidoptera of Norfolk Island, p. 281.

\section{PYRALOIDEA}

\section{PYRALIDAE}

\section{ENDOTRICHINAE}

Endotricha dyschroa Turner

Endotricha sp. Turner, 1917. Transactions and Proceedings of the Royal Society of South Australia 41: 56.

Endotricha dyschroa Turner, 1918. Transactions and Proceedings of the Royal Society of South Australia 42: 284.

Endotricha dyschroa Turner. Hawkins, 1943. Annals and Magazine of Natural History, London (11)9(60): 872.

Endotricha dyschroa Turner. Turner, Smithers \& Hoogland, 1968. The Conservation of Norfolk Island, p. 40.

Endotricha dyschroa Turner. Holloway, 1977a. Lepidoptera of Norfolk Island, p. 278.

Endotricha mesenterialis (Walker)

Endotricha mesenterialis obscura Butler. Holloway, 1977a. Lepidoptera of Norfolk Island, p. 279.

\section{PHYCITINAE}

Crocydopora cinigerella (Walker)

Crocydopora cinigerella (Walker). Turner, 1917. Transactions and Proceedings of the Royal Society of South Australia 41: 56.

Crocydopora cinigerella (Walker). Turner, 1918. Transactions and Proceedings of the Royal Society of South Australia 42: 288.

Crocydopora cinigerella (Walker). Hawkins, 1943. Annals and Magazine of Natural History, London (11)9(60): 872.

Crocydopora cinigerella (Walker). Holloway, 1977a. Lepidoptera of Norfolk Island, p. 278.

?Cryptoblabes plagioleuca Turner

?Cryptoblabes plagioleuca Turner. (?= Eurhodope ardescens Meyrick) Holloway, 1977a. Lepidoptera of Norfolk Island, p. 278.
Cryptoblabes sp.

Cryptoblabes sp. Holloway, 1977a. Lepidoptera of Norfolk Island, p. 278.

Etiella behrii (Zeller)

Etiella behrii (Zeller). Holloway, 1977a. Lepidoptera of Norfolk Island, p. 278.

Nephopterix sp.

Nephopterix sp. near thermalopha Lower. Holloway, 1977a. Lepidoptera of Norfolk Island, p. 278.

Oligochroa oculiferella (Meyrick)

Oligochroa oculiferella (Meyrick). Holloway, 1977a. Lepidoptera of Norfolk Island, p. 278.

Phycitinae spp. Holloway, 1977a. Lepidoptera of Norfolk Island, p. 279.

\section{CRAMBINAE}

Calamatropha sp.

Crambinae sp. Holloway, 1977a. Lepidoptera of Norfolk Island, p. 278.

Calamatropha sp. Holloway, 1982. Journal of Natural History 16(3): 358.

Crambus sp.

Crambus sp. Hawkins, 1943. Annals and Magazine of Natural History, London (11)9(60): 872.

Crambus sp. Turner, Smithers \& Hoogland, 1968. The Conservation of Norfolk Island, p. 40.

Culladia cuneiferellus (Walker)

Crambus cuneiferellus Walker. Meyrick, 1886. Transactions of the entomological Society of London 1888: 269.

Crambus cuneiferellus Walker. Turner, 1917. Transactions and Proceedings of the Royal Society of South Australia 41: 56.

Crambus cuneiferellus Walker. Turner, 1918. Transactions and Proceedings of the Royal Society of South Australia 42: 288.

Crambus cuneiferellus Walker. Hawkins, 1943. Annals and Magazine of Natural History, London (11)9(60): 872.

Culladia cuneiferellus (Walker). Holloway, 1977a. Lepidoptera of Norfolk Island, p. 278.

\section{NYMPHULINAE}

Nymphulinae sp. Holloway, 1977a. Lepidoptera of Norfolk Island, p. 279.

\section{SCOPARIINAE}

Scoparia sp.

Scoparia sp. Hawkins, 1943. Annals and Magazine of Natural History, London (11)9(60): 872.

Scoparia sp. Turner, Smithers \& Hoogland, 1968. The Conservation of Norfolk Island, p. 40.

Scoparia tritocirrha Turner

Scoparia sp. Turner, 1917. Transactions and Proceedings of the Royal Society of South Australia 41: 56.

Scoparia tritocirrha Turner, 1918. Transactions and Proceedings of the Royal Society of South Australia 42: 286.

Scoparia tritocirrha Turner. Hawkins, 1943. Annals and Magazine of Natural History, London (11)9(60): 872.

Scoparia tritocirrha Turner. Turner, Smithers \& Hoogland, 1968. The Conservation of Norfolk Island, p. 40.

Scoparia tritocirrha Turner. Holloway, 1977a. Lepidoptera of Norfolk Island, p. 279. 


\section{EVERGESTINAE}

Crocidoloma binotalis Zeller

Godara comalis Guenée. Meyrick, 1886. Transactions of the entomological Society of London 1886: 264.

Godara comalis Guenée (?= Crocidoloma binotalis Zeller). Hawkins, 1943. Annals and Magazine of Natural History, London (11)9(60): 873.

Crocidoloma binotalis Zeller. Holloway, 1984. Proceedings and Transactions of the British entomological and natural History Society 17(3): 67.

\section{Crocidoloma sp.}

Crocidoloma sp. near illustris Lucas. Holloway, 1977a. Lepidoptera of Norfolk Island, p. 280.

Crocidoloma sp. Holloway, 1982. Journal of Natural History 16(3): 358

\section{GLAPHYRIINAE}

Hellula hydralis Guenée

Hellula hydralis Guenée. Holloway, 1977a. Lepidoptera of Norfolk Island, p. 280.

Hellula undalis (Fabricius)

Hellula undalis (Fabricius). Holloway, 1982. Journal of Natural History 16(3): 358.

\section{PYRAUSTINAE}

Hydriris ornatalis (Duponchel)

Ercta ornatalis Duponchel. Hawkins, 1943. Annals and Magazine of Natural History, London (11)9(60): 867, 873.

Antiercta ornatalis (Duponchel). Holloway, 1977a. Lepidoptera of Norfolk Island, p. 279.

Botyodes asialis Guenée

Botyodes asialis (Guenée). Holloway, 1977a. Lepidoptera of Norfolk Island, p. 279.

Diaphania indica (Saunders)

Diaphania indica (Saunders). Holloway, 1977a. Lepidoptera of Norfolk Island, p. 280.

Diasemia delosticha Turner

!Diasemia grammalis Doubleday. Meyrick, 1886. Transactions of the entomological Society of London 1886: 239.

Diasemia delosticha Turner, 1917. Transactions and Proceedings of the Royal Society of South Australia 41: 56.

Diasemia delosticha Turner. Turner, 1918. Transactions and Proceedings of the Royal Society of South Australia 42: 285.

Diasemia delosticha Turner. Hawkins, 1943. Annals and Magazine of Natural History, London (11)9(60): 866.

!Diasemia grammalis Doubleday (probably Diasemia delosticha Turner). Hawkins, 1943. Annals and Magazine of Natural History, London (11)9(60): 873.

Diasemia delosticha Turner. Turner, Smithers \& Hoogland, 1968. The Conservation of Norfolk Island, p. 40.

!Diasemia grammalis Doubleday. Turner, Smithers \& Hoogland, 1968. The Conservation of Norfolk Island, p. 40.

Diasemia delosticha Turner. Holloway, 1977a. Lepidoptera of Norfolk Island, p. 280.

Diasemia ramburialis Duponchel

Diasemia ramburialis Duponchel. Holloway, 1977a. Lepidoptera of Norfolk Island, p. 282.

Cnaphalocrocis stereogona (Meyrick)

Epimima (Marasmia) stereogona (Meyrick). Holloway, 1977a. Lepidoptera of Norfolk Island, p. 280.
Epimima stereogona (Meyrick). Holloway, 1982. Journal of Natural History 16(3): 358.

Epipagis cancellalis Zeller

Epipagis cancellalis Zeller. Holloway, 1982. Journal of Natural History 16(3): 358.

Eurrhyparodes sp.

Eurrhyparodes sp. (E. bracteolalis Zeller or E. tricoloralis Zeller groups). Holloway, 1977a. Lepidoptera of Norfolk Island, p. 280.

Herpetogramma (Psara) licarsisalis (Walker)

Acharana licarsisalis Walker. Turner, 1917. Transactions and Proceedings of the Royal Society of South Australia 41: 56.

Acharana licarsisalis Walker. Hawkins, 1943. Annals and Magazine of Natural History, London (11)9(60): 873.

Herpetogramma (Psara) licarsisalis (Walker). Holloway, 1977a. Lepidoptera of Norfolk Island, p. 280.

Hymenia recurvalis (Fabricius)

Hymenia fascialis (Cramer). Turner, 1917. Transactions and Proceedings of the Royal Society of South Australia 41: 56.

Hymenia recurvalis (Fabricius). Hawkins, 1943. Annals and Magazine of Natural History, London (11)9(60): 873.

Hymenia recurvalis (Fabricius). Holloway, 1977a. Lepidoptera of Norfolk Island, p. 280.

Hymenia recurvalis (Fabricius). Holloway, 1982. Journal of Natural History 16(3): 358.

Ischnurges illustralis Lederer

Ischnurges illustralis Lederer. Holloway, 1977a. Lepidoptera of Norfolk Island, p. 280.

Lamprosoma diemenalis (Guenée)

Lamprosoma diemenalis (Guenée). Holloway, 1977a. Lepidoptera of Norfolk Island, p. 280.

Loxostege affinitalis Lederer

Loxostege affinitalis Lederer. Holloway, 1977a. Lepidoptera of Norfolk Island, p. 280.

Loxostege affinitalis Lederer. Holloway, 1984. Proceedings and Transactions of the British entomological and natural History Society 17(3): 67.

Marasmia poeyalis Boisduval

Marasmia poeyalis Boisduval. Holloway, 1982. Journal of Natural History 16(3): 358.

Maruca testulalis (Geyer)

Maruca testulalis (Geyer). Holloway, 1977a. Lepidoptera of Norfolk Island, p. 280.

Maruca testulalis (Geyer). Holloway, 1982. Journal of Natural History 16(3): 358.

Maruca testulalis (Geyer). Holloway, 1984. Proceedings and Transactions of the British entomological and natural History Society 17(3): 67.

Metasia sp. near capnochroa Meyrick

Metasia sp. near capnochroa Meyrick. Holloway, 1977a. Lepidoptera of Norfolk Island, p. 280.

Metasia sp. near mosaica Meyrick

Metasia sp. near mosaica Meyrick. Holloway, 1977a. Lepidoptera of Norfolk Island, p. 280.

Nomophila australica Munroe

Nomophila australica Munroe. Holloway, 1977a. Lepidoptera of Norfolk Island, p. 281.

Nomophila australica Munroe. Holloway, 1982. Journal of Natural History 16(3): 358. 
Palpita sp.

Margaronia sp. Hawkins, 1943. Annals and Magazine of Natural History, London (11)9(60): 873.

Margaronia sp. Turner, Smithers \& Hoogland, 1968. The Conservation of Norfolk Island, p. 40.

Palpita sp. Holloway, 1977a. Lepidoptera of Norfolk Island, p. 281.

Palpita unionalis Hubner

Palpita unionalis Hubner. Holloway, 1977a. Lepidoptera of Norfolk Island, p. 281.

Pygospila tyres (Cramer)

Pygospila tyres (Cramer). Holloway, 1977a. Lepidoptera of Norfolk Island, p. 281.

Pyrausta sp.

Pyrausta sp. Holloway, 1977a. Lepidoptera of Norfolk Island, p. 281

Sceliodes cordalis (Doubleday)

Sceliodes cordalis (Doubleday). Holloway, 1977a. Lepidoptera of Norfolk Island, p. 281.

Salbia haemorrhoidalis Guenée

Syngamia haemorrhoidalis abruptalis Walker. Holloway, 1977a. Lepidoptera of Norfolk Island, p. 281.

Terastia meticulosalis Guenée

Terastia meticulosalis Guenée. Holloway, 1977a. Lepidoptera of Norfolk Island, p. 281.

Terastia meticulosalis Guenée. Holloway, 1982. Journal of Natural History 16(3): 358.

Terastia meticulosalis Guenée. Holloway, 1984. Proceedings and Transactions of the British entomological and natural History Society 17(3): 67.

Trichophysetis neophyla Meyrick

Trichophysetis neophyla Meyrick. Meyrick, 1886. Transactions of the entomological Society of London 1886: 218.

!Trichophysetis cretacea Butler. Turner, 1917. Transactions and Proceedings of the Royal Society of South Australia 51: 56.

Trichophysetis neophyla Meyrick. Hawkins, 1943. Annals and Magazine of Natural History, London (11)9(60): 867, 872.

Trichophysetis neophyla Meyrick. Holloway, 1977a. Lepidoptera of Norfolk Island, p. 281.

Uresiphita ornithopteralis (Guenée)

Uresiphita ornithopteralis (Guenée). Holloway, 1977a. Lepidoptera of Norfolk Island, p. 281.

Uresiphita ornithopteralis (Guenée). Holloway, 1982. Journal of Natural History 16(3): 358.

Uresiphita ornithopteralis (Guenée). Holloway, 1984. Proceedings and Transactions of the British entomological and natural History Society 17(3): 69.

\section{GEOMETROIDEA}

\section{GEOMETRIDAE}

\section{ENNOMINAE}

\section{Cleora idiocrossa Turner}

Boarmia sp. Turner, 1917. Transactions and Proceedings of the Royal Society of South Australia 41: 55.

Cleora sp. Turner, 1918. Transactions and Proceedings of the Royal Society of South Australia 42: 283.

Cleora idiocrossa Turner, 1918. Transactions and Proceedings of the Royal Society of South Australia 42: 284, 289.

Cleora idiocrossa Turner. Hawkins, 1943. Annals and Magazine of Natural History, London (11)9(60): 872.
Cleora idiocrossa Turner. Holloway, 1976a. Norfolk Island Philatelic Bulletin 1976(2): (3), (pages not numbered).

Cleora idiocrossa Turner. Holloway, 1977a. Lepidoptera of Norfolk Island, p. 135, figs. 105, 106; pl. 29, figs. 9, 10.

Cleora idiocrossa Turner. Holloway, 1984. Proceedings and Transactions of the British entomological and natural History Society 17(3): 69.

Pseudocoremia christiani Holloway

Pseudocoremia christiani Holloway, 1977b. Norfolk Island Philatelic Bulletin 1977(1): (1), illustrated (pages and illustrations not numbered).

Pseudocoremia christiani Holloway. Holloway, 1977a. Lepidoptera of Norfolk Island, p. 136, figs. 104, 107, 108; pl. 29, figs. 11, 12.

\section{GEOMETRINAE}

Agathia jowettorum Holloway

?Agathia distributa Lucas. Hawkins, 1943. Annals and Magazine of Natural History, London (11)9(60): 871.

Agathia asterias jowettorum Holloway, 1977a. Lepidoptera of Norfolk Island, p. 118, figs. 74, 75; pl. 28, fig. 1.

Agathia asterias Meyrick. Holloway, 1979. A survey of the Lepidoptera, biogeography and ecology of New Caledonia p. 271.

Agathia jowettorum Holloway. Holloway, 1984. Proceedings and Transactions of the British entomological and natural History Society 17(3): 68.

Pyrrhorachis pyrrhogona (Walker)

Pyrrhorachis pyrrhogona subcrenulata Holloway, 1976b. Norfolk Island Philatelic Bulletin 1976(3): (2), illustrated (pages and illustrations not numbered).

Pyrrhorachis pyrrhogona subcrenulata Holloway. Holloway, 1977a. Lepidoptera of Norfolk Island, p. 120, fig. 77; pl. 28 , fig. 6.

Pyrrhorachis pyrrhogona subcrenulata Holloway. Holloway, 1982. Journal of Natural History 16(3): 359.

Urolitha quintali Holloway

Urolitha quintali Holloway, 1977a. Lepidoptera of Norfolk Island, p. 121, figs. 78, 79; pl. 26, fig. 2.

\section{STERRHINAE}

Scopula hypochroa (Meyrick)

Acidalia hypochroa Meyrick. Turner, 1917. Transactions and Proceedings of the Royal Society of South Australia 51: 55.

Acidalia hypochroa Meyrick. Turner. 1918. Transactions and Proceedings of the Royal Society of South Australia 42: 288.

Scopula hypochroa (Meyrick). Hawkins, 1943. Annals and Magazine of Natural History, London (11)9(60): 872.

Scopula hypochroa (Meyrick). Holloway, 1977a. Lepidoptera of Norfolk Island, p. 121, figs. 82, 84; pl. 28, fig. 3.

Scopula optivata (Walker)

Scopula sp. Hawkins, 1943. Annals and Magazine of Natural History, London (11)9(60): 872.

Scopula sp. Turner, Smithers \& Hoogland, 1968. The Conservation of Norfolk Island, p. 40.

Scopula optivata youngi Holloway, 1977a. Lepidoptera of Norfolk Island, p. 122, fig. 80; pl. 28, fig. 4.

Scopula rubraria (Doubleday)

Acidalia rubraria (Doubleday). Meyrick, 1886. Transactions of the entomological Society of London 1886: 206.

Acidalia rubraria (Doubleday). Olliff, 1888a. Proceedings of the Linnean Society of New South Wales (2)2(4): 1014. 
Acidalia rubraria (Doubleday). Turner, 1917. Transactions and Proceedings of the Royal Society of South Australia 41: 55.

Acidalia rubraria (Doubleday). Turner, 1918. Transactions and Proceedings of the Royal Society of South Australia 42: 288.

Scopula rubraria (Doubleday). Hawkins, 1943. Annals and Magazine of Natural History, London (11)9(60): 866, 871.

Scopula rubraria (Doubleday). Holloway, 1977a. Lepidoptera of Norfolk Island, p. 124, figs. 81, 83; pl. 28, fig. 7.

\section{LARENTIINAE}

Austrocidaria ralstonae Holloway

Austrocidaria ralstonae Holloway, 1977a. Lepidoptera of Norfolk Island, p. 125, figs. 86, 87; pl. 29, fig. 2.

Austrocidaria ralstonae Holloway. Holloway, 1984. Proceedings and Transactions of the British entomological and natural History Society 17(3): 68.

Chloroclystis filata Meyrick

Chloroclystis filata Meyrick. Holloway, 1982. Journal of Natural History 16(3): 360.

Chloroclystis insigillata (Walker)

Chloroclystis insigillata (Walker). Holloway, 1977a. Lepidoptera of Norfolk Island, p. 127; pl. 29, fig. 7.

Chloroclystis insigillata (Walker). Holloway, 1982. Journal of Natural History 16(3): 359.

Chloroclystis insigillata (Walker). Holloway, 1984. Proceedings and Transactions of the British entomological and natural History Society 17(3): 69.

Chloroclystis testulata (Guenée)

Chloroclystis testulata nobbsi Holloway, 1977a. Lepidoptera of Norfolk Island, p. 127, figs. 88-90; pl. 28, fig. 8.

Eccymatoge callizona (Lower)

Eccymatoge callizona minor Holloway, 1977a. Lepidoptera of Norfolk Island, p. 129, fig. 92; pl. 29, fig.1.

Eccymatoge callizona minor Holloway. Holloway, 1982. Journal of Natural History 16(3): 359.

Eccymatoge callizona minor Holloway. Holloway, 1984. Proceedings and Transactions of the British entomological and natural History Society 17(3): 69.

Gymnoscelis acidna Turner

Gymnoscelis acidna Turner. Holloway, 1977a. Lepidoptera of Norfolk Island, p. 130, figs. 93-95; pl. 29, fig. 6.

Micrulia tenuilinea Warren

Micrulia tenuilinea Warren. Holloway, 1977a. Lepidoptera of Norfolk Island, p. 131, fig. 101; pl. 29, fig. 5.

Micrulia tenuilinea Warren. Holloway, 1979. A survey of the Lepidoptera, biogeography and ecology of New Caledonia p. 315, fig. 60(2).

\section{Phrissogonus laticostata (Walker)}

Chloroclystis laticostata (Walker). Turner, 1917. Transactions and Proceedings of the Royal Society of South Australia 41: 55.

Chloroclystis laticostata (Walker). Turner, 1918. Transactions and Proceedings of the Royal Society of South Australia 42: 288.

Chloroclystis laticostata (Walker). Hawkins, 1943. Annals and Magazine of Natural History, London (11)9(60): 872.

Phrissogonus laticostata (Walker). Holloway, 1977a. Lepidoptera of Norfolk Island, p. 132, figs. 96-98; pl. 28 , fig. 1 .
Phrissogonus laticostata (Walker). Holloway, 1979. A survey of the Lepidoptera, biogeography and ecology of New Caledonia p. 317.

Phrissogonus laticostata (Walker). Common, 1990. Moths of Australia p. 376, fig. 37.18.

Sauris curvicosta Prout

Sauris curvicosta Prout. Holloway, 1977a. Lepidoptera of Norfolk Island, p. 133, fig. 85; pl. 29, fig. 8.

Sauris curvicosta Prout. Holloway, 1982. Journal of Natural History 16(3): 359.

Xanthorhö̈ sodaliata (Walker)

Xanthorhö̈ sodaliata (Walker). Turner, 1917. Transactions and Proceedings of the Royal Society of South Australia 41: 55.

Xanthorhö̈ sodaliata (Walker). Turner, 1918. Transactions and Proceedings of the Royal Society of South Australia 42: 288.

Xanthorhoë sodaliata (Walker). Hawkins, 1943. Annals and Magazine of Natural History, London (11)9(60): 866,872 .

Xanthorhoë sodaliata (Walker). Holloway, 1976a. Norfolk Island Philatelic Bulletin 1976(2): (1), (pages not numbered).

Xanthorhoë sodaliata (Walker). Holloway, 1977a. Lepidoptera of Norfolk Island, p. 133, fig. 91; pl. 28, figs. 9, 10.

Xanthorhoё sodaliata (Walker). Holloway, 1979. A survey of the Lepidoptera, biogeography and ecology of New Caledonia p. 320.

Ziridava smithersi Holloway

Ziridava smithersi Holloway, 1977a. Lepidoptera of Norfolk Island, p. 135, figs. 99, 100, 102, 103; pl. 29, figs. 3, 4.

Ziridava smithersi Holloway. Holloway, 1984. Proceedings and Transactions of the British entomological and natural History Society 17(3): 69.

\section{PAPILIONOIDEA}

\section{PAPILIONIDAE}

\section{PAPILIONINAE}

Graphium macleayanum (Leach)

Papilio macleayanus Leach. Scott, 1893. Australian Lepidoptera with their transformations... 2(4): 31; pl. XX.

Papilio macleayanus Leech (sic). Hawkins, 1943. Annals and Magazine of Natural History, London (11)9(60): 870.

Graphium macleayanum (Leach). Smithers \& Peters, 1969. Australian Zoologist 15: 185.

Graphium macleayanum (Leach). Smithers, 1970a. Proceedings of the Royal zoological Society of New South Wales 1968-1969: 47.

Graphium macleayanum (Leach). Smithers, 1970b. Norfolk Island Butterflies p. 8, pl I.

Graphium macleayanum insularum (Waterhouse). Common \& Waterhouse, 1972. Butterflies of Australia p. 171.

Graphium macleayanum (Leach). Smithers \& Evans, 1974. Australian entomological Magazine 2(1): 9.

Graphium macleayanum (Leach). Holloway, 1977a. Lepidoptera of Norfolk Island, p. 56.

Graphium macleayanum insularum (Waterhouse). Common \& Waterhouse, 1981. Butterflies of Australia p. 235.

[It is unlikely that this species is established on Norfolk Island. All references are based on that of Scott (1893).] 
Papilio aegeus (Fabricius)

Papilio aegeus (Fabricius). Rainbow, 1907. A guide to the study of Australian butterflies, p. 202.

[It is unlikely that this species is established on Norfolk Island. There has been no reference to it on the island since that of Rainbow (1907).]

Papilio ilioneus Donovan

Papilio ilioneus Donovan, 1805. An epitome of the natural history of the Insects of New Holland, New Zealand... etc. Text and plate not numbered.

Papilio amphiaraus Felder. Olliff, 1888a. Proceedings of the Linnean Society of New South Wales (2)2(4): 1013.

Papilio amphiaraus Felder. Olliff, 1889. Australian Butterflies. A brief account of the native families p. 39.

Papilio amyntor amphiaraus Felder. Tindale, 1923. Transactions and Proceedings of the Royal Society of South Australia 47: 351; pl. XXX, fig. 29.

Papilio amphiaraus Felder. Hawkins, 1943. Annals and Magazine of Natural History, London (11)9(60): 866, 870.

Papilio ilioneus Donovan. Smithers \& Peters, 1969. Australian Zoologist 15: 185.

Papilio ilioneus Donovan. Smithers, 1970a. Proceedings of the Royal zoological Society of New South Wales 19681969: 46.

Papilio ilioneus ilioneus Donovan. Smithers, 1970b. Norfolk Island Butterflies p. 9, pl I.

Papilio amynthor ilioneus Donovan. D'Abrera, 1971. Butterflies of the Australian Region. Pp. 100, 101.

Papilio ilioneus ilioneus Donovan. Smithers \& Evans, 1974. Australian entomological Magazine 2(1): 9.

Papilio ilioneus Donovan. Holloway \& Peters, 1976. Journal of Natural History 10: 284.

Papilio ilioneus Donovan. Holloway, 1977a. Lepidoptera of Norfolk Island, p. 53.

\section{PIERIDAE}

\section{PIERINAE}

\section{Anaphaeis java (Sparrman)}

Pieris java Sparrman. Olliff, 1888a. Proceedings of the Linnean Society of New South Wales (2)2(4): 1013.

Anaphaeis java peristhene (Boisduval). Hawkins, 1943. Annals and Magazine of Natural History, London (11)9(60): 868 .

Anaphaeis java peristhene (Boisduval). Smithers \& Peters, 1969. Australian Zoologist 15: 185.

Anaphaeis java peristhene (Boisduval). Smithers, 1970a. Proceedings of the Royal zoological Society of New South Wales 1968-1969: 47.

Anaphaeis java peristhene (Boisduval). Smithers, 1970b. Norfolk Island Butterflies. P. 10, pl I.

Anaphaeis java peristhene (Boisduval). Smithers \& Evans, 1974. Australian entomological Magazine 2(1): 9.

Anaphaeis java peristhene (Boisduval). Holloway \& Peters, 1976. Journal of Natural History 10: 284.

Anaphaeis java peristhene (Boisduval). Holloway, 1977a. Lepidoptera of Norfolk Island, p. 56.

Anaphaeis java peristhene (Boisduval). Common \& Waterhouse, 1981. Butterflies of Australia p. 291.

Belenois java peristhene (Boisduval). Nielsen, Edwards \& Rangsi, 1996. Monographs on Australian Lepidoptera 4: 359 .

\section{Cepora perimale (Donovan)}

Papilio perimale Donovan, 1805. An epitome of the natural history of the Insects of New Holland, New Zealand... etc. Text and plate not numbered.

Belenois perimale Donovan. Olliff, 1889. Australian Butterflies. A brief account of the native families p. 29.

Huphina perimale (Donovan). Waterhouse \& Lyell, 1914. The Butterflies of Australia. P. 145.

Cepora perimale perimale (Donovan). Hawkins, 1943. Annals and Magazine of Natural History, London (11)9(60): 866, 868.

Cepora perimale perimale (Donovan). Smithers \& Peters, 1969. Australian Zoologist 15: 185, 186.

Cepora perimale perimale (Donovan). Smithers, 1970a. Proceedings of the Royal zoological Society of New South Wales 1968-1969: 46.

Cepora perimale perimale (Donovan). Smithers, $1970 \mathrm{~b}$. Norfolk Island Butterflies p. 11, pl II.

Cepora perimale perimale (Donovan). Smithers \& Evans, 1974. Australian entomological Magazine 2(1): 9.

Cepora perimale perimale (Donovan). Holloway \& Peters, 1976. Journal of Natural History 10: 292.

Cepora perimale perimale (Donovan). Holloway, 1977a. Lepidoptera of Norfolk Island, p. 53.

Pierid

Pierid. Olliff, 1887. Abstract. Proceedings of the Linnean Society of New South Wales 28th June, 1887: vii.

\section{NYMPHALIDAE}

\section{DANAINAE}

Danaus chrysippus (Linnaeus)

Danaus chrysippus petilia (Stoll). Evans, 1981. Australian entomological Magazine 8(4): 54.

Danaus chrysippus petilia (Stoll). Ackery \& Vane-Wright, 1984. Milkweed Butterflies, their cladistics and biology p. 153.

Danaus plexippus (Linnaeus).

Anosia plexippus (Linnaeus). Walker, 1886. Entomologist's monthly Magazine 22: 223.

Danaus plexippus (Linnaeus). Olliff, 1888a. Proceedings of the Linnean Society of New South Wales (2)2(4): 1013.

Danaus plexippus (Linnaeus). Hawkins, 1943. Annals and Magazine of Natural History, London (11)9(60): 868.

Danaus menippe Hubner. Hawkins, 1943. Annals and Magazine of Natural History, London (11)9(60): 868.

Danaus plexippus (Linnaeus). Smithers \& Peters, 1969. Australian Zoologist 15: 185, 186.

Danaus plexippus (Linnaeus). Smithers, 1970a. Proceedings of the Royal zoological Society of New South Wales 1968-1969: 46.

Danaus plexippus (Linnaeus). Smithers, 1970b. Norfolk Island Butterflies p. 12; pl. I.

Danaus plexippus plexippus (Linnaeus). Common \& Waterhouse, 1972. Butterflies of Australia p. 221; pl. 22, fig. 1.

Danaus plexippus (Linnaeus). Smithers \& Evans, 1974. Australian entomological Magazine 2(1): 9.

Danaus plexippus (Linnaeus). Holloway \& Peters, 1976. Journal of Natural History 10: 296.

Danaus plexippus (Linnaeus). Holloway, 1977a. Lepidoptera of Norfolk Island, p. 56.

Danaus plexippus (Linnaeus). Common \& Waterhouse, 1981. Butterflies of Australia p. 302; pl. 24, fig. 1. 
Danaus (Danaus) plexippus (Linnaeus). Ackery \& Vane-Wright, 1984. Milkweed Butterflies, their cladistics and biology $\mathrm{p}$. 15; pl. 15, fig. 90; pl. IX, fig. 100; pl. XI, fig. 134.

Euploea core (Cramer)

Euploea core corinna (W.S. Macleay). Evans, 1977. Australian entomological Magazine 3(6): 106.

Euploea core corinna (W.S. Macleay). Holloway, 1982. Journal of Natural History 16(3): 358.

Euploea core corinna (W.S. Macleay). Ackery \& VaneWright, 1984. Milkweed Butterflies, their cladistics and biology p. 153.

Tirumala hamata (W.S. Macleay)

Tirumala hamata (W.S. Macleay). Smithers, 1995. Norfolk Nature Notes 11(3): 395.

Tirumala hamata (W.S. Macleay). Evans, 1995. Norfolk Nature Notes 11(3): 396.

Tirumala hamata (W.S. Macleay). Early, Parrish \& Ryan, 1995. Records of the Auckland Institute and Museum 32: 52.

Tirumala hamata (W.S. Macleay). Anonymous. 1996. Norfolk Nature Notes 12(2): 7.

\section{SATYRINAE}

Melanitis leda (Linnaeus)

Melanitis leda bankia (Fabricius). Smithers, 1975. Australian entomological Magazine 2(5): 110.

Melanitis leda (Linnaeus). Holloway, 1977a. Lepidoptera of Norfolk Island, p. 56.

\section{NYMPHALINAE}

\section{Hypolimnas bolina (Linnaeus)}

Hypolimnas bolina (Linnaeus). Mathew, 1888. Transactions of the entomological Society of London 1888(1): 151.

Diadema bolina (Linnaeus). Olliff, 1888a. Proceedings of the Linnean Society of New South Wales (2)2(4): 1013.

Hypolimnas bolina (Linnaeus). Olliff, 1889. Australian Butterflies. A brief account of the native families p. 17.

Hypolimnas bolina (Linnaeus). Rainbow, 1907. A guide to the study of Australian butterflies. Pp. 69, 79, 80, figs. 48.

Hypolimnas bolina (Linnaeus). Poulton, 1924. Transactions of the entomological Society of London 1923(3-4): 647.

Hypolimnas bolina (Linnaeus). Hawkins, 1943. Annals and Magazine of Natural History, London (11)9(60): 868.

Hypolimnas bolina (Linnaeus). Smithers \& Peters, 1969. Australian Zoologist 15: 185, 186.

Hypolimnas bolina (Linnaeus). Smithers, 1970a. Proceedings of the Royal zoological Society of New South Wales 1968-1969: 47.

Hypolimnas bolina (Linnaeus). Smithers, 1970b. Norfolk Island Butterflies p. 13; pl. II.

Hypolimnas bolina nerina (Linnaeus). Common \& Waterhouse, 1972. Butterflies of Australia p. 287; pl. 28, figs. 7, 7A.

Hypolimnas bolina (Linnaeus). Smithers \& Evans, 1974. Australian entomological Magazine 2(1): 9.

Hypolimnas bolina nerina (Fabricius). Holloway, 1976a. Norfolk Island Philatelic Bulletin 1976(2): (2), illustrated (pages and illustrations not numbered)

Hypolimnas bolina (Linnaeus). Holloway, 1977a. Lepidoptera of Norfolk Island, p. 56.

Hypolimnas bolina (Linnaeus). Holloway, 1982. Journal of Natural History 16(3): 358.

Hypolimnas bolina nerina (Fabricius). Common \& Waterhouse, 1981. Butterflies of Australia p. 391; pl. 36, figs. 7, 7A.
Hypolimnas misippus (Linnaeus)

Hypolimnas misippus (Linnaeus). Evans, 1977. Australian entomological Magazine 3(6): 106.

Hypolimnas misippus (Linnaeus). Holloway, 1982. Journal of Natural History 16(3): 358.

Junonia villida (Fabricius)

Junonia villida (Fabricius). Rainbow, 1907. A guide to the study of Australian butterflies pp. 63, 75, figs. 43, 33, 45, 46, 47.

Precis villida calybe (Godart). Smithers \& Peters, 1969. Australian Zoologist 15: 185.

Precis villida calybe (Godart). Smithers, 1970a. Proceedings of the Royal zoological Society of New South Wales 1968-1969: 47.

Precis villida calybe (Godart). Smithers, 1970b. Norfolk Island Butterflies. P. 16; pl. II.

Precis villida calybe (Godart). Common \& Waterhouse, 1972. Butterflies of Australia p. 294; pl. 29, fig. 2.

Precis villida calybe (Godart). Smithers \& Evans, 1974. Australian entomological Magazine 2(1): 9.

Precis villida calybe (Godart). Holloway \& Peters, 1976. Journal of Natural History 10: 306.

Precis villida calybe (Godart). Holloway, 1976a. Norfolk Island Philatelic Bulletin 1976(2): (3), (pages not numbered).

Precis villida calybe (Godart). Holloway, 1977a. Lepidoptera of Norfolk Island, p. 56.

Junonia villida calybe (Godart). Common \& Waterhouse, 1981. Butterflies of Australia p. 402; pl. 37, fig. 2.

Precis villida calybe (Godart). Holloway, 1982. Journal of Natural History 16(3): 358.

Vanessa itea (Fabricius)

Vanessa itea (Fabricius). Olliff, 1887. Abstract of Proceedings of the Linnean Society of New South Wales 28th June, 1887: vii.

Pyrameis itea (Fabricius). Olliff, 1888a. Proceedings of the Linnean Society of New South Wales (2)2(4): 1013.

Pyrameis itea (Fabricius). Olliff, 1889. Australian Butterflies p. 15.

Pyrameis itea (Fabricius). Rainbow, 1907. A guide to the study of Australian butterflies pp. 57, 67, figs. 37, 38, 39, 40.

Pyrameis itea (Fabricius). Hawkins, 1943. Annals and Magazine of Natural History, London (11)9(60): 868.

Vanessa itea (Fabricius). Smithers \& Peters, 1969. Australian Zoologist 15: 185.

Vanessa itea (Fabricius). Smithers, 1970a. Proceedings of the Royal zoological Society of New South Wales 19681969: 46, 47.

Vanessa itea (Fabricius). Smithers, 1970b. Norfolk Island Butterflies p. 15; pl. II.

Vanessa itea (Fabricius). Common \& Waterhouse, 1972. Butterflies of Australia p. 292; pl. 29, fig. 6.

Vanessa itea (Fabricius). Smithers \& Evans, 1974. Australian entomological Magazine 2(1): 9.

Bassaris itea (Fabricius). Holloway, 1976a. Norfolk Island Philatelic Bulletin 1976(2): (2), illustrated (pages and illustrations not numbered).

Bassaris itea (Fabricius). Holloway, 1977a. Lepidoptera of Norfolk Island, p. 56.

Vanessa itea (Fabricius). Common \& Waterhouse, 1981. Butterflies of Australia p. 399; pl. 37, fig. 6.

Vanessa itea (Fabricius). Evans, 1984. Norfolk Nature Notes 1(2): 4.

Vanessa kershawi (McCoy)

Vanessa kershawi (McCoy). Smithers \& Peters, 1969. Australian Zoologist 15: 185. 
Vanessa kershawi (McCoy). Smithers, 1969. Australian Zoologist 15: 188.

Vanessa kershawi (McCoy). Smithers, 1970a. Proceedings of the Royal zoological Society of New South Wales 1968-1969: 46.

Vanessa kershawi (McCoy). Smithers, 1970b. Norfolk Island Butterflies p. 14, pl II.

Vanessa kershawi (McCoy). Common \& Waterhouse, 1972. Butterflies of Australia p. 291; pl. 29, fig. 5.

Vanessa kershawi (McCoy). Smithers \& Evans, 1974. Australian entomological Magazine 2(1): 9.

Vanessa kershawi (McCoy). Holloway \& Peters, 1976. Journal of Natural History 10: 306.

Cynthia kershawi (McCoy). Holloway, 1976a. Norfolk Island Philatelic Bulletin 1976(2): (2), illustrated (pages and illustrations not numbered).

Cynthia kershawi (McCoy). Holloway, 1977a. Lepidoptera of Norfolk Island, p. 56.

Vanessa kershawi (McCoy). Common \& Waterhouse, 1981. Butterflies of Australia p. 397; pl. 37, fig. 5.

\section{LYCAENIDAE}

\section{POLYOMMATINAE}

Lampides boeticus (Linnaeus)

Lycaena boeticus (Linnaeus). Scott. 1890. Australian Lepidoptera with their transformations... etc. Vol. 2, Pt. I, p. 10, footnote.

Lampides boeticus (Linnaeus). Smithers, 1970a. Proceedings of the Royal zoological Society of New South Wales 1968-1969: 47.

Lampides boeticus (Linnaeus). Smithers, 1970b. Norfolk Island Butterflies. P. 18; pl. II.

Lampides boeticus (Linnaeus). Holloway, 1977a. Lepidoptera of Norfolk Island, p. 56.

Lampides boeticus (Linnaeus). Smithers \& Evans, 1974. Australian entomological Magazine 2(1): 9.

Zizina labradus (Godart)

Zizena labradus (Godart). Hawkins, 1943. Annals and Magazine of Natural History, London (11)9(60): 868. (Misprint for Zizina).

Zizeeria otis labradus (Godart). Smithers \& Peters, 1969. Australian Zoologist 15: 186.

Zizina otis labradus (Godart). Smithers, 1970a. Proceedings of the Royal zoological Society of New South Wales 1968-1969: 46, 47.

Zizina otis labradus (Godart). Smithers, 1970b. Norfolk Island Butterflies p. 17; pl. II.

Zizina otis labradus (Godart). Common \& Waterhouse, 1981. Butterflies of Australia p. 409; pl. 38, figs. 14, 14A.

Zizina otis labradus (Godart). Smithers \& Evans, 1974. Australian entomological Magazine 2(1): 9.

Zizina otis labradus (Godart). Holloway, 1977a. Lepidoptera of Norfolk Island, p. 56.

Zizina labradus labradus (Godart). Common \& Waterhouse, 1981. Butterflies of Australia p. 586; pl. 49, figs. 14, 14A.

\section{SPHINGOIDEA}

\section{SPHINGIDAE}

\section{SPHINGINAE}

Agrius convolvuli (Linnaeus)

Protoparce convolvuli (Linnaeus) var. distans (Butler). Olliff, 1888a. Proceedings of the Linnean Society of New South Wales (2)2(4): 1014.

Herse convolvuli (Linnaeus). Turner, 1917. Transactions and Proceedings of the Royal Society of South Australia 41: 56.

Herse convolvuli (Linnaeus). Hawkins, 1943. Annals and Magazine of Natural History, London (11)9(60): 871.

Agrius convolvuli (Linnaeus). Holloway, 1977a. Lepidoptera of Norfolk Island, p. 116; pl. 27, fig. 5.

Agrius convolvuli (Linnaeus). Holloway, 1982. Journal of Natural History 16(3): 360.

\section{MACROGLOSSINAE}

Gnathothlibus erotus (Cramer)

Gnathothlibus erotus (Cramer). Holloway, 1984. Proceedings and Transactions of the British entomological and natural History Society 17(3): 68.

Hippotion celerio (Linnaeus)

Hippotion celerio (Linnaeus). Holloway, 1977a. Lepidoptera of Norfolk Island, p. 116; pl. 27, fig. 4.

Hippotion scrofa (Boisduval)

Hippotion scrofa (Boisduval). Holloway, 1976b. Norfolk Island Philatelic Bulletin 1976(3): (2), illustrated (pages and illustrations not numbered).

Hippotion scrofa (Boisduval). Holloway, 1977a. Lepidoptera of Norfolk Island, p. 116; pl. 27, fig. 3.

Hippotion scrofa (Boisduval). Holloway, 1979. A survey of the Lepidoptera, biogeography and ecology of New Caledonia p. 355.

Hippotion scrofa (Boisduval). Holloway, 1984. Proceedings and Transactions of the British entomological and natural History Society 17(3): 67.

Hippotion scrofa (Boisduval). Common, 1990. Moths of Australia p. 414; pl. 16, fig.10.

Hippotion velox (Fabricius)

Hippotion velox (Fabricius). Holloway, 1977a. Lepidoptera of Norfolk Island, p. 116; pl. 27, fig. 1.

Hippotion velox (Fabricius). Holloway, 1984. Proceedings and Transactions of the British entomological and natural History Society 17(3): 67.

Hippotion velox (Fabricius). Holloway, 1979. A survey of the Lepidoptera, biogeography and ecology of New Caledonia p. 355.

Macroglossum hirundo Boisduval

Macroglossum hirundo Boisduval. Holloway, 1977a. Lepidoptera of Norfolk Island, p. 117; pl. 27, fig. 2.

Macroglossum hirundo Boisduval. Holloway, 1979. A survey of the Lepidoptera, biogeography and ecology of New Caledonia p. 356.

Macroglossum hirundo Boisduval. Holloway, 1982. Journal of Natural History 16(3): 360.

Macroglossum hirundo Boisduval. Holloway, 1984. Proceedings and Transactions of the British entomological and natural History Society 17(3): 68. 


\section{NOCTUOIDEA}

\section{ARCTIIDAE}

\section{ARCTIINAE}

Nyctemera amica (White)

Nyctemera amica (White). Holloway, 1982. Journal of Natural History 16(3): 360.

\section{Utetheisa pulchelloides Hampson}

Deiopeia pulchella (Linnaeus). Olliff, 1888a. Proceedings of the Linnean Society of New South Wales (2)2(4): 1014.

Utetheisa pulchella (Linnaeus). Hawkins, 1943. Annals and Magazine of Natural History, London (11)9(60): 870 (probably U. pulchelloides Hampson).

Utetheisa pulchelloides vaga Jordan. Holloway, 1976b. Norfolk Island Philatelic Bulletin 1976(3): (2), illustrated (pages and illustrations not numbered).

Utetheisa pulchelloides vaga Jordan. Holloway, 1977a. Lepidoptera of Norfolk Island, p. 59; pl. 20, fig. 1.

Utetheisa pulchelloides Hampson. Holloway, 1982. Journal of Natural History 16(3): 361.

Utetheisa pulchelloides Hampson. Holloway, 1984. Proceedings and Transactions of the British entomological and natural History Society 17(3): 68.

\section{LITHOSIINAE}

\section{Nesiotica cladara Turner}

Nesiotica cladara Turner, 1917. Transactions and Proceedings of the Royal Society of South Australia 41: 54.

Nesiotica cladara Turner. Turner, 1918. Transactions and Proceedings of the Royal Society of South Australia 42: 284.

Nesiotica cladara Turner. Hawkins, 1943. Annals and Magazine of Natural History, London (11)9(60): 870.

Nesiotica cladara Turner. Turner, Smithers \& Hoogland, 1968. The Conservation of Norfolk Island, p. 40.

Nesiotica cladara Turner. Holloway, 1977a. Lepidoptera of Norfolk Island, p. 58, figs. 9, 10; pl. 24, fig. 12.

Nesiotica cladara Turner. Holloway, 1984. Proceedings and Transactions of the British entomological and natural History Society 17(3): 69 .

\section{NOCTUIDAE}

\section{RIVULINAE}

Rivula sp.

Rivula sp. Hawkins, 1943. Annals and Magazine of Natural History, London (11)9(60): 871.

Rivula sp. Turner, Smithers \& Hoogland, 1968. The Conservation of Norfolk Island, p. 40.

\section{HYPENODINAE}

\section{Hydrillodes norfolki Holloway}

!Hydrillodes lentalis Guenée. Turner, 1917. Transactions and Proceedings of the Royal Society of South Australia 41: 55.

Hydrillodes sp. (not lentalis). Hawkins, 1943. Annals and Magazine of Natural History, London (11)9(60): 871.

Hydrillodes sp. Turner, Smithers \& Hoogland, 1968. The Conservation of Norfolk Island, p. 40.

Hydrillodes norfolki Holloway, 1977a. Lepidoptera of Norfolk Island, p. 95, figs. 41, 45, 46; pl. 25, figs. 3, 6, 9.

Hydrillodes norfolki norfolki Holloway. Holloway, 1979. A survey of the Lepidoptera, biogeography and ecology of New Caledonia p. 532, fig. 148(2).
Luceria cooki Holloway

Luceria cooki Holloway, 1977a. Lepidoptera of Norfolk Island, p. 100, figs. 51, 52; pl. 24, fig. 9.

Luceria cooki Holloway. Holloway, 1979. A survey of the Lepidoptera, biogeography and ecology of New Caledonia p. 533, fig. 151(3).

Schrankia costaestrigalis (Stephens)

Schrankia costaestrigalis (Stephens). Holloway, 1977a. Lepidoptera of Norfolk Island, p. 112, fig. 50; pl. 26, fig. 18.

Schrankia daviesi Holloway

Schrankia daviesi Holloway, 1977a. Lepidoptera of Norfolk Island, p. 109, figs. 57, 72; pl. 26, figs. 16, 17.

Simplicia caeneusalis (Walker)

Simplicia caeneusalis buffetti Holloway, 1977a. Lepidoptera of Norfolk Island, p. 112, figs. 48, 49; pl. 25, figs. 7, 8 .

Trigonistis andersoni Holloway

Trigonistis andersoni Holloway, 1977a. Lepidoptera of Norfolk Island, p. 113, figs. 40, 73; pl. 24, figs. 1, 3.

\section{HYPENINAE}

Hypena hoareae Holloway

Hypena hoareae Holloway, 1977a. Lepidoptera of Norfolk Island, p. 97, fig. 43; pl. 25, fig. 5.

Hypena hoareae Holloway. Holloway, 1982. Journal of Natural History 16(3): 364.

Hypena laceratalis Walker

Hypena laceratalis Walker. Holloway, 1977a. Lepidoptera of Norfolk Island, p. 98, fig. 44; pl. 25, fig. 4.

Hypena laceratalis Walker. Common, 1990. Moths of Australia p. 448, fig. 44.7.

Hypena masurialis Guenée

Hypena masurialis Guenée. Turner, 1917. Transactions and Proceedings of the Royal Society of South Australia 41: 55.

Hypena masurialis Guenée. Hawkins, 1943. Annals and Magazine of Natural History, London (11)9(60): 871. (=ferriscitalis Walker).

Hypena masurialis ferriscitalis Walker. Holloway, 1977a. Lepidoptera of Norfolk Island, p. 99, fig. 47; pl. 25, figs. 1, 2.

Pectinidia silvicola Holloway

Pectinidia silvicola Holloway, 1977a. Lepidoptera of Norfolk Island, p. 93, figs. 37, 38; pl. 22, fig. 2.

?Pectinidia silvicola Holloway. Nielsen, Edwards \& Rangsi, 1996. Monographs on Australian Lepidoptera 4: 371.

\section{CATOCALINAE}

Achaea janata (Linnaeus)

Achaea melicerte Druce. Olliff, 1888a. Proceedings of the Linnean Society of New South Wales (2)2(4): 1014.

Achaea melicerta [sic] Druce. Hawkins, 1943. Annals and Magazine of Natural History, London (11)9(60): 871.

Achaea janata (Linnaeus). Holloway, 1977a. Lepidoptera of Norfolk Island, p. 80; pl. 23, fig. 9.

Achaea janata (Linnaeus). Holloway, 1979. A survey of the Lepidoptera, biogeography and ecology of New Caledonia p. 461.

Achaea janata (Linnaeus). Holloway, 1982. Journal of Natural History 16(3): 362.

Achaea janata (Linnaeus). Holloway, 1984. Proceedings and Transactions of the British entomological and natural History Society 17(3): 70. 
Anomis flava (Fabricius)

Anomis flava (Fabricius). Holloway, 1977a. Lepidoptera of Norfolk Island, p. 84, fig. 31; pl. 22, fig. 10.

Anomis flava (Fabricius). Holloway, 1982. Journal of Natural History 16(3): 363.

Anomis involuta (Walker)

Anomis involuta (Walker). Holloway, 1977a. Lepidoptera of Norfolk Island, p. 85, fig. 34; pl. 22, fig. 5.

Anomis involuta involuta (Walker). Holloway, 1979. A survey of the Lepidoptera, biogeography and ecology of New Caledonia p. 483.

Anomis involuta (Walker). Holloway, 1982. Journal of Natural History 16(3): 363.

Anomis involuta (Walker). Holloway, 1984. Proceedings and Transactions of the British entomological and natural History Society 17(3): 68.

Anomis lyona (Swinhoe)

Anomis lyona (Swinhoe). Holloway, 1977a. Lepidoptera of Norfolk Island, p. 86, fig. 32; pl. 22, fig. 15.

Anomis lyona (Swinhoe). Holloway, 1979. A survey of the Lepidoptera, biogeography and ecology of New Caledonia p. 484.

Anomis lyona (Swinhoe). Common, 1990. Moths of Australia, p. 449.

Anticarsia irrorata (Fabricius)

Anticarsia irrorata (Fabricius). Holloway, 1977a. Lepidoptera of Norfolk Island, p. 86; pl. 23, fig. 1.

Anticarsia irrorata (Fabricius). Holloway, 1979. A survey of the Lepidoptera, biogeography and ecology of New Caledonia p. 486

Avatha discolor (Fabricius)

Avatha discolor (Fabricius). Holloway, 1984. Proceedings and Transactions of the British entomological and natural History Society 17(3): 68.

Dasypodia cymatodes Guenée

Dasypodia cymatodes Guenée. Holloway, 1977a. Lepidoptera of Norfolk Island, p. 282.

Dasypodia cymatodes Guenée. Holloway, 1982. Journal of Natural History 16(3): 363.

Dasypodia selenophora Guenée

Dasypodia selenophora Guenée. Hawkins, 1943. Annals and Magazine of Natural History, London (11)9(60): 871.

Dasypodia selenophora Guenée. Holloway, 1977a. Lepidoptera of Norfolk Island, p. 86; pl. 23, fig. 12.

Dasypodia selenophora Guenée. Holloway, 1982. Journal of Natural History 16(3): 363.

Ericeia hirsutitarsus Holloway

Ericeia hirsutitarsus Holloway. Holloway, 1977a. Lepidoptera of Norfolk Island, p. 88, fig. 35; pl. 23, figs. 5, 6.

Ericeia hirsutitarsus hirsutitarsus Holloway. Holloway, 1979. A survey of the Lepidoptera, biogeography and ecology of New Caledonia p. 493, fig. 123(2); pl. 86, fig. 5.

Ericeia hirsutitarsus Holloway. Holloway, 1982. Journal of Natural History 16(3): 363.

Eudesmeola lawsoni (Felder)

Eudesmeola lawsoni (Felder). Holloway, 1977a. Lepidoptera of Norfolk Island, p. 90; pl. 23, fig. 11.

Hypocala deflorata (Fabricius)

Hypocala deflorata australiae Butler. Holloway, 1977a. Lepidoptera of Norfolk Island, p. 90; pl. 23, fig. 4.
Hypocala deflorata australiae Butler. Holloway, 1982. Journal of Natural History 16(3): 363.

Hypocala deflorata australiae Butler. Holloway, 1984. Proceedings and Transactions of the British entomological and natural History Society 17(3): 68.

Hypocala deflorata australiae Butler. Common, 1990. Moths of Australia p. 450; pl. 20, fig. 12.

Lacera noctilio (Fabricius)

Lacera noctilio (Fabricius). Holloway, 1982. Journal of Natural History 16(3): 363.

Mocis frugalis (Fabricius)

Mocis frugalis (Fabricius). Hawkins, 1943. Annals and Magazine of Natural History, London (11)9(60): 871.

Mocis frugalis (Fabricius). Holloway, 1977a. Lepidoptera of Norfolk Island, p. 80; pl. 23, fig. 2.

Mocis trifasciatus (Stephens)

Mocis trifasciatus (Stephens). Holloway, 1977a. Lepidoptera of Norfolk Island, p. 81.

Ophiusa disjungens (Walker)

Ophiusa disjungens (Walker). Holloway, 1982. Journal of Natural History 16(3): 362.

Othreis fullonia (Clerck)

Othreis fullonia (Clerck). Holloway, 1984. Proceedings and Transactions of the British entomological and natural History Society 17(3): 68.

Othreis materna (Linnaeus)

Othreis materna (Linnaeus). Holloway, 1977a. Lepidoptera of Norfolk Island, p. 90; pl. 23, fig. 10.

Pantydia sparsa Guenée

Pantydia sparsa Guenée. Holloway, 1977a. Lepidoptera of Norfolk Island, p. 91; pl. 23, fig. 8.

Pantydia sparsa Guenée. Holloway, 1982. Journal of Natural History 16(3): 363.

Pantydia sparsa Guenée. Holloway, 1984. Proceedings and Transactions of the British entomological and natural History Society 17(3): 69.

Pantydia sparsa Guenée. Common, 1990. Moths of Australia p. 450 , fig. 44.19 .

Spheirodonia spectans (Guenée)

Spheirodonia spectans (Guenée). Holloway, 1984. Proceedings and Transactions of the British entomological and natural History Society 17(3): 68.

Tathorrhynchus exsiccata (Lederer)

Tathorrhynchus exsiccata fallax Swinhoe. Holloway, 1977a. Lepidoptera of Norfolk Island, p. 94, fig. 36; pl. 21, fig. 15.

Tathorrhynchus exsiccata fallax Swinhoe. Holloway, 1982. Journal of Natural History 16(3): 363.

Tathorrhynchus exsiccata (Lederer). Holloway, 1984. Proceedings and Transactions of the British entomological and natural History Society 17(3): 68.

Tathorrhynchus exsiccata fallax Swinhoe. Common, 1990. Moths of Australia p. 452, fig. 45.1.

Trigonodes hyppasia (Cramer)

Trigonodes hyppasia (Cramer). Holloway, 1977a. Lepidoptera of Norfolk Island, p. 81; pl. 23, fig. 3.

Trigonodes hyppasia (Cramer). Holloway, 1979. A survey of the Lepidoptera, biogeography and ecology of New Caledonia p. 478.

Trigonodes hyppasia (Cramer). Holloway, 1982. Journal of Natural History 16(3): 362 .

Trigonodes hyppasia (Cramer). Common, 1990. Moths of Australia p. 452, fig. 46.5. 


\section{CUCULIINAE}

Neogalea esula (Druce)

Neogalea esula (Druce). Holloway, 1977a. Lepidoptera of Norfolk Island, p. 68; pl. 21, fig. 3.

Neogalea esula (Druce). Holloway, 1979. A survey of the Lepidoptera, biogeography and ecology of New Caledonia p. 423.

\section{ACONTIINAE}

Amyna natalis (Walker)

Amyna natalis (Walker). Holloway, 1977a. Lepidoptera of Norfolk Island, p. 72; pl. 22, fig. 6.

Amyna natalis (Walker). Holloway, 1979. A survey of the Lepidoptera, biogeography and ecology of New Caledonia p. 426.

Amyna natalis (Walker). Holloway, 1982. Journal of Natural History 16(3): 361.

Amyna natalis (Walker). Holloway, 1984. Proceedings and Transactions of the British entomological and natural History Society 17(3): 69.

Amyna natalis (Walker). Common, 1990. Moths of Australia p. 456 , fig. 47.14 .

Amyna octo (Guenée)

Amyna octo (Guenée). Holloway, 1977a. Lepidoptera of Norfolk Island, p. 73; pl. 22, fig. 7.

Amyna punctatum (Fabricius)

Amyna punctatum (Fabricius). Holloway, 1982. Journal of Natural History 16(3): 361.

\section{NOLINAE}

Nola insularum (Collenette)

Nola insularum (Collenette). Holloway, 1977a. Lepidoptera of Norfolk Island, p. 56, fig. 8; pl. 24, fig. 10.

Nola transversata Robinson

Nola transversata adamsi Holloway, 1977a. Lepidoptera of Norfolk Island, p. 57, fig. 7; pl. 24, fig. 11.

\section{CHLOEPHORINAE}

Austrocarea albipicta (Hampson)

Austrocarea albipicta (Hampson). Holloway, 1977a. Lepidoptera of Norfolk Island, p. 76.

Austrocarea iocephala (Turner)

Austrocarea iocephala millsi Holloway, 1976a. Norfolk Island Philatelic Bulletin 1976(2): (3), (pages not numbered).

Austrocarea iocephala millsi Holloway. Holloway, 1976b. Norfolk Island Philatelic Bulletin 1976(3): (1) (pages and illustrations not numbered).

Austrocarea iocephala millsi Holloway. Holloway, 1977a. Lepidoptera of Norfolk Island, p. 77, figs. 28-30; pl. 22, fig. 3 .

Austrocarea orthoscia (Warren)

Austrocarea orthoscia (Warren). Holloway, 1977a. Lepidoptera of Norfolk Island, p. 77.

\section{Earias parallela Lucas}

Earias parallela Lucas. Holloway, 1984. Proceedings and Transactions of the British entomological and natural History Society 17(3): 68 .

Earias perhuegeli Holloway

Earias huegeli auctt. Holloway, 1977a. Lepidoptera of Norfolk Island, p. 78.
Earias perhuegeli Holloway, 1977a. Lepidoptera of Norfolk Island, p. 78; pl. 22, fig. 8.

Earias perhuegeli ab. huegeliana Strand. Holloway, 1977a. Lepidoptera of Norfolk Island, p. 78, fig. 22; pl. 22, fig. 9.

Earias perhuegeli Holloway. Holloway, 1979. A survey of the Lepidoptera, biogeography and ecology of New Caledonia p. 459, fig. 113(2).

\section{PLUSIINAE}

Chrysodeixis acuta (Walker)

Chrysodeixis acuta (Walker). Holloway, 1982. Journal of Natural History 16(3): 362.

Chrysodeixis argentifera (Guenée)

Plusia argentifera Guenée. Holloway, 1977a. Lepidoptera of Norfolk Island, p. 83; pl. 22, fig. 13.

Plusia argentifera Guenée. Holloway, 1982. Journal of Natural History 16(3): 362.

Chrysodeixis argentifera (Guenée). Common, 1990. Moths of Australia p. 459, fig. 48.15 .

Chrysodeixis eriosoma (Doubleday)

Plusia chalcites Esper. Hawkins, 1943. Annals and Magazine of Natural History, London (11)9(60): 871.

Chrysodeixis eriosoma (Doubleday). Holloway, 1977a. Lepidoptera of Norfolk Island, p. 81, fig. 26; pl. 22, fig. 12.

Chrysodeixis eriosoma (Doubleday). Holloway, 1982. Journal of Natural History 16(3): 362.

Chrysodeixis maccoyi Holloway

Chrysodeixis maccoyi Holloway, 1977a. Lepidoptera of Norfolk Island, p. 83, fig. 27; pl. 22, fig. 11.

Ctenoplusia albostriata (Bremer and Grey)

Ctenoplusia albostriata (Bremer and Grey). Holloway, 1977a. Lepidoptera of Norfolk Island, p. 83; pl. 22, fig. 14.

Ctenoplusia albostriata (Bremer and Grey). Holloway, 1979. A survey of the Lepidoptera, biogeography and ecology of New Caledonia p. 481.

Ctenoplusia albostriata (Bremer and Grey). Common, 1990. Moths of Australia p. 459, fig. 48.14.

\section{ACRONICTINAE}

Athetis tenuis (Butler)

Proxenus tenuis (Butler). Turner, 1917. Transactions and Proceedings of the Royal Society of South Australia 41: 55.

Proxenus tenuis (Butler). Hawkins, 1943. Annals and Magazine of Natural History, London (11)9(60): 866, 870.

Athetis tenuis (Butler). Holloway, 1977a. Lepidoptera of Norfolk Island, p. 67, figs. 18, 19; pl. 21, fig. 11.

Athetis tenuis (Butler). Holloway, 1979. A survey of the Lepidoptera, biogeography and ecology of New Caledonia p. 412.

Atheris tenuis (Butler). Holloway, 1982. Journal of Natural History 16(3): 361.

Cosmodes elegans (Donovan)

Cosmodes elegans (Donovan). Holloway, 1977a. Lepidoptera of Norfolk Island, p. 67, fig. 15; pl. 21, fig. 14.

Cosmodes elegans (Donovan). Holloway, 1982. Journal of Natural History 16(3): 361.

Cosmodes elegans (Donovan). Holloway, 1984. Proceedings and Transactions of the British entomological and natural History Society 17(3): 68.

Cosmodes elegans (Donovan). Common, 1990. Moths of Australia p. 460; pl. 22, fig. 7. 
Hypoperigea tonsa (Guenée)

Hypoperigea tonsa (Guenée). Holloway, 1977a. Lepidoptera of Norfolk Island, p. 67, figs. 16, 17; pl. 21, fig. 4.

Leucocosmia monagrica (Walker)

Elydna thoracica Moore. Hawkins, 1943. Annals and Magazine of Natural History, London (11)9(60): 866, 870.

Leucocosmia nonagrica (Walker). Holloway, 1977a. Lepidoptera of Norfolk Island, p. 68; pl. 21, figs. 12, 13.

Maliattha ritsemae (Snellen)

Maliattha ritsemae (Snellen). Holloway, 1977a. Lepidoptera of Norfolk Island, p. 73; pl. 22, fig. 1.

Maliattha ritsemae (Snellen). Holloway, 1979. A survey of the Lepidoptera, biogeography and ecology of New Caledonia p. 437.

Maliattha ritsemae (Snellen). Holloway, 1982. Journal of Natural History 16(3): 361.

Platysenta conducta (Walker)

Platysenta conducta (Walker). Holloway, 1977a. Lepidoptera of Norfolk Island, p. 68; pl. 21, fig. 9.

Platysenta conducta (Walker). Holloway, 1979. A survey of the Lepidoptera, biogeography and ecology of New Caledonia p. 423.

Platysenta conducta (Walker). Holloway, 1984. Proceedings and Transactions of the British entomological and natural History Society 17(3): 68.

Platysenta dolorosa (Walker)

Platysenta dolorosa (Walker). Holloway, 1977a. Lepidoptera of Norfolk Island, p. 69, fig. 20, 21; pl. 21, fig. 5.

Platysenta dolorosa (Walker). Holloway, 1979. A survey of the Lepidoptera, biogeography and ecology of New Caledonia p. 423.

Platysenta dolorosa (Walker). Holloway, 1982. Journal of Natural History 16(3): 361.

Platysenta dolorosa (Walker). Holloway, 1984. Proceedings and Transactions of the British entomological and natural History Society 17(3): 68.

Platysenta illecta (Walker)

Ariathisa sp. Turner, 1917. Transactions and Proceedings of the Royal Society of South Australia 41: 55.

Perigea capensis Guenée. Turner, 1918. Transactions and Proceedings of the Royal Society of South Australia 42: 283, 288

Perigea illecta (Walker). Hawkins, 1943. Annals and Magazine of Natural History, London (11)9(60): 870.

Platysenta illecta (Walker). Holloway, 1977a. Lepidoptera of Norfolk Island, p. 69; pl. 21, fig. 10.

Platysenta illecta (Walker). Holloway, 1979. A survey of the Lepidoptera, biogeography and ecology of New Caledonia p. 423.

Spodoptera exigua (Hubner)

Spodoptera exigua (Hubner). Holloway, 1977a. Lepidoptera of Norfolk Island, p. 70; pl. 21, fig. 8.

Spodoptera litura (Fabricius)

Prodenia litura (Fabricius). Turner, 1917. Transactions and Proceedings of the Royal Society of South Australia 41: 55.

Prodenia litura (Fabricius). Hawkins, 1943. Annals and Magazine of Natural History, London (11)9(60): 870.

Spodoptera litura (Fabricius). Holloway, 1977a. Lepidoptera of Norfolk Island, p. 70; pl. 21, figs. 1, 2.

Spodoptera mauritia (Boisduval)

Spodoptera nubes (Guenée). Hawkins, 1943. Annals and Magazine of Natural History, London (11)9(60): 870.
Spodoptera mauritia (Boisduval). Holloway, 1976a. Norfolk Island Philatelic Bulletin 1976(2): (2), (pages not numbered).

Spodoptera mauritia acronyctoides Guenée. Holloway, 1977a. Lepidoptera of Norfolk Island, p. 72; pl. 21, figs. 6, 7.

Spodoptera mauritia (Boisduval). Holloway, 1982. Journal of Natural History 16(3): 361.

Trissernis greeni Holloway

Trissernis greeni Holloway. Holloway, 1977a. Lepidoptera of Norfolk Island, p. 73, fig. 24; pl. 24, fig. 6.

Trissernis greeni Holloway. Holloway, 1982. Journal of Natural History 16(3): 361.

Trissernis greeni Holloway. Holloway, 1979. A survey of the Lepidoptera, biogeography and ecology of New Caledonia p. 438.

\section{HADENINAE}

Mythimna loreyimima (Rungs)

Cirphis loreyi Duponchel. Turner, 1917. Transactions and Proceedings of the Royal Society of South Australia 41: 55.

Leucania loreyi (Duponchel). Hawkins, 1943. Annals and Magazine of Natural History, London (11)9(60): 870.

Leucania loreyimima Rungs. Holloway, 1976a. Norfolk Island Philatelic Bulletin 1976(2): (1), (2) illustrated (pages and illustrations not numbered).

Leucania loreyimima Rungs. Holloway, 1977a. Lepidoptera of Norfolk Island, p. 64, figs. 11, 12, pl. 20, fig. 6.

Leucania loreyimima Rungs. Holloway, 1979. A survey of the Lepidoptera, biogeography and ecology of New Caledonia p. 402.

Mythimna convecta (Walker)

Pseudaletia convecta evansi Holloway, 1977a. Lepidoptera of Norfolk Island, p. 66; pl. 20, fig. 8.

Mythimna separata (Walker)

Cirphis unipuncta Haworth. Turner, 1917. Transactions and Proceedings of the Royal Society of South Australia 41: 55.

Leucania unipuncta (Haworth). Hawkins, 1943. Annals and Magazine of Natural History, London (11)9(60): 866, 870.

Pseudaletia separata (Walker). Holloway, 1977a. Lepidoptera of Norfolk Island, p. 65; pl. 20, fig. 7.

Tiracola plagiata (Walker)

Tiracola plagiata (Walker). Holloway, 1976b. Norfolk Island Philatelic Bulletin 1976(3): (2), illustrated (pages and illustrations not numbered).

Tiracola plagiata (Walker). Holloway, 1977a. Lepidoptera of Norfolk Island, p. 66; pl. 20, fig. 9, 10.

\section{NOCTUINAE}

Agrotis infusa (Boisduval)

Agrotis infusa (Boisduval). Holloway, 1977a. Lepidoptera of Norfolk Island, p. 60; pl. 20, fig. 4.

Agrotis infusa (Boisduval). Holloway, 1982. Journal of Natural History 16(3): 361.

Agrotis infusa (Boisduval). Holloway, 1984. Proceedings and Transactions of the British entomological and natural History Society 17(3): 68 .

Agrotis infusa (Boisduval). Common, 1990. Moths of Australia p. 467, figs. 50.5, 55.15.

Agrotis ipsilon (Hufnagel)

Agrotis ypsilon (Hufnagel). Turner, 1917. Transactions and Proceedings of the Royal Society of South Australia 41: 55. (Referred to as Agrotis ypsilon Rott.).

Agrotis ipsilon [sic] (Hufnagel). Hawkins, 1943. Annals and Magazine of Natural History, London (11)9(60): 866, 870. 
Agrotis ypsilon aneituma (Walker). Common, 1958. Australian Journal of Zoology 6: 73; pl. 1, figs. 1, 2. Agrotis ipsilon [sic] aneituma (Walker). Holloway, 1977a. Lepidoptera of Norfolk Island, p. 60; pl. 20, fig. 3.

Agrotis munda Walker

Agrotis munda Walker. Common, 1958. Australian Journal of Zoology 6: 77; pl. 2, figs. 1, 2.

Agrotis munda Walker. Holloway, 1977a. Lepidoptera of Norfolk Island, p. 62; pl. 20, fig. 12.

Agrotis munda Walker. Holloway, 1979. A survey of the Lepidoptera, biogeography and ecology of New Caledonia p. 399.

Agrotis munda Walker. Holloway, 1982. Journal of Natural History 16(3): 361.

Agrotis munda Walker. Holloway, 1984. Proceedings and Transactions of the British entomological and natural History Society 17(3): 68.

Agrotis munda Walker. Common, 1990. Moths of Australia p. 467 , fig. 50.6 .

Agrotis radians Guenée

Euxoa radians (Guenée). Zeck, 1930. Australian Naturalist 8(2): 33, fig. 4.

Diarsia intermixta (Guenée)

Diarsia intermixta (Guenée). Holloway, 1977a. Lepidoptera of Norfolk Island, p. 62, figs. 13, 14; pl. 20, fig. 5.

\section{HELIOTHINAE}

\section{Helicoverpa armigera (Hubner)}

Helicoverpa armigera conferta (Walker). Holloway, 1977a. Lepidoptera of Norfolk Island, p. 62; pl. 20, fig. 12.

Helicoverpa armigera (Walker). Holloway, 1982. Journal of Natural History 16(3): 361.

Helicoverpa assulta (Guenée)

Helicoverpa assulta assulta (Guenée). Holloway, 1977a. Lepidoptera of Norfolk Island, p. 63; pl. 20, fig. 11.

Helicoverpa assulta assulta (Guenée). Holloway, 1982. Journal of Natural History 16(3): 361.

Heliothis assulta Guenée. Holloway, 1984. Proceedings and Transactions of the British entomological and natural History Society 17(3): 68 .

\section{Helicoverpa punctigera (Wallengren)}

Helicoverpa punctigera (Wallengren). Holloway, 1977a. Lepidoptera of Norfolk Island, p. 63; pl. 20, fig. 13.

Helicoverpa punctigera (Wallengren). Holloway, 1982. Journal of Natural History 16(3): 361.

Heliothis punctigera Wallengren. Holloway, 1984. Proceedings and Transactions of the British entomological and natural History Society 17(3): 68.

Heliothis (Helicoverpa) punctigera Wallengren. Common, 1990. Moths of Australia p. 468, fig. 50.9.

Heliothis rubrescens (Walker)

Heliothis rubrescens (Walker). Holloway, 1977a. Lepidoptera of Norfolk Island, p. 63; pl. 20, fig. 14, 15.

Heliothis rubrescens (Walker). Holloway, 1982. Journal of Natural History 16(3): 361

\section{HYMENOPTERA}

\section{APOCRITA}

\section{CERAPHRONOIDEA}

\section{CERAPHRONIDAE}

Ceraphron sp.

Ceraphron sp. Dodd, 1924. Transactions and Proceedings of the Royal Society of South Australia 48: 174.

Ceraphron sp. Hawkins, 1943. Annals and Magazine of Natural History, London (11)9(60): 881.

\section{ICHNEUMONOIDEA}

\section{ICHNEUMONIDAE}

\section{PIMPLINAE}

Echthromorpha sp.

Echthromorpha sp. Hawkins, 1943. Annals and Magazine of Natural History, London (11)9(60): 880.

Lissopimpla sp.

Lissopimpla sp. Holloway, 1977a. Lepidoptera of Norfolk Island, p. 282.

Xanthopimpla sp.

Xanthopimpla sp. Hawkins, 1943. Annals and Magazine of Natural History, London (11)9(60): 880.

\section{TRYPHONINAE}

Netelia sp.

Netelia sp. Holloway, 1977a. Lepidoptera of Norfolk Island, p. 282.

\section{OPHIONINAE}

Enicospilus sp.

Enicospilus sp. Holloway, 1977a. Lepidoptera of Norfolk Island, p. 282.

Ophion sp.

Ophion sp. Hawkins, 1943. Annals and Magazine of Natural History, London (11)9(60): 880.

\section{BRACONIDAE}

Apanteles sp.

Apanteles sp. Hawkins, 1943. Annals and Magazine of Natural History, London (11)9(60): 880.

Aphidius spp.

Aphidius spp. Hawkins, 1943. Annals and Magazine of Natural History, London (11)9(60): 880.

Hende sp.

Hende sp. Holloway, 1977a. Lepidoptera of Norfolk Island, p. 282.

Microdus sp.

Microdus sp. Hawkins, 1943. Annals and Magazine of Natural History, London (11)9(60): 880.

Phanerotoma sp.

Phanerotoma sp. Holloway, 1977a. Lepidoptera of Norfolk Island, p. 282.

Zele sp.

Zele sp. Holloway, 1977a. Lepidoptera of Norfolk Island, p. 282. 


\section{PROCTOTRUPOIDEA}

\section{DIAPRIIDAE}

Trichopria norfolcensis (Dodd)

Phaenopria norfolcensis Dodd, 1924. Transactions and Proceedings of the Royal Society of South Australia 48: 181. Phaenopria norfolcensis Dodd. Hawkins, 1943. Annals and Magazine of Natural History, London (11)9(60): 882.

Spilomicrus sp.

Spilomicrus sp. (near gracilis Dodd). Dodd, 1924. Transactions and Proceedings of the Royal Society of South Australia 48: 182.

Spilomicrus sp. (near gracilis Dodd). Hawkins, 1943. Annals and Magazine of Natural History, London (11)9(60): 882.

Tetramopria plana Dodd

Tetramopria plana Dodd, 1924. Transactions and Proceedings of the Royal Society of South Australia 48: 181.

Tetramopria plana Dodd. Hawkins, 1943. Annals and Magazine of Natural History, London (11)9(60): 882.

\section{PLATYGASTEROIDEA}

\section{SCELIONIDAE}

\section{SCELIONINAE}

\section{Hadronotus sp.}

Hadronotus sp. (near parvipennis Dodd). Dodd, 1924. Transactions and Proceedings of the Royal Society of South Australia 48: 180

Hadronotus sp. Hawkins, 1943. Annals and Magazine of Natural History, London (11)9(60): 882.

\section{TELEASINAE}

Trimorus leai Dodd

Trimorus leai Dodd, 1924. Transactions and Proceedings of the Royal Society of South Australia 48: 176.

Trimorus leai Dodd. Hawkins, 1943. Annals and Magazine of Natural History, London (11)9(60): 882.

Trimorus norfolcensis Dodd

Trimorus norfolcensis Dodd, 1924. Transactions and Proceedings of the Royal Society of South Australia 48: 176.

Trimorus norfolcensis Dodd. Hawkins, 1943. Annals and Magazine of Natural History, London (11)9(60): 882.

\section{CHALCIDOIDEA}

\section{CHALCIDIDAE}

\section{CHALCIDINAE}

Chalcis sp.

Chalcis sp. (near atrata Kirby). Dodd, 1924. Transactions and Proceedings of the Royal Society of South Australia 48: 162.

Chalcis sp. (near atrata Kirby). Hawkins, 1943. Annals and Magazine of Natural History, London (11)9(60): 880.

[Chalcis atrata Kirby = Brachymeria lugubris (Walker). Boucek, 1988. Australian Chalcidoidea p. 71].

Chalcis sp.

Chalcis sp. (near victoria Girault). Dodd, 1924. Transactions and Proceedings of the Royal Society of South Australia 48: 162.

Chalcis sp. (near victoria Girault). Hawkins, 1943. Annals and Magazine of Natural History, London (11)9(60): 880.
$[$ Chalcis victoria $($ Girault $)=$ Brachymeria victoria $($ Girault $)$. Boucek, 1988. Australian Chalcidoidea p. 74].

\section{PTEROMALIDAE}

\section{CLEONYMINAE}

Cleonymus imperialis (Dodd)

Aplatygerrhus imperialis Dodd, 1924. Transactions and Proceedings of the Royal Society of South Australia 48: 163.

Aplatygerrhus imperialis Dodd. Hawkins, 1943. Annals and Magazine of Natural History, London (11)9(60): 881.

Cleonymus imperialis (Dodd). Boucek, 1988. Australian Chalcidoidea p. 263.

Parusios truncatipennis (Dodd)

Lelaps truncatipennis Dodd, 1924. Transactions and Proceedings of the Royal Society of South Australia 48: 167.

Lelaps truncatipennis Dodd. Hawkins, 1943. Annals and Magazine of Natural History, London (11)9(60): 881.

Parusios truncatipennis (Dodd). Boucek, 1988. Australian Chalcidoidea p. 335.

\section{DIPARINAE}

Ophelosia leai Dodd

Ophelosia leai Dodd, 1924. Transactions and Proceedings of the Royal Society of South Australia 48: 169.

Ophelosia leai Dodd. Hawkins, 1943. Annals and Magazine of Natural History, London (11)9(60): 881.

Ophelosia leai Dodd. Boucek, 1988. Australian Chalcidoidea p. 354.

\section{EUNOTINAE}

Moranila californica (Howard)

Tomocera californica Howard. Dodd, 1924. Transactions and Proceedings of the Royal Society of South Australia 48: 169.

Tomocera californica Howard. Hawkins, 1943. Annals and Magazine of Natural History, London (11)9(60): 881.

\section{PTEROMALINAE}

Callitula viridicoxa (Girault)

Polycystomyia benefica Dodd. Dodd, 1924. Transactions and Proceedings of the Royal Society of South Australia 48: 172.

Polycystomyia benefica Dodd. Hawkins, 1943. Annals and Magazine of Natural History, London (11)9(60): 881.

?Pseudanogmus silanus (Walker)

?Pseudanogmus fasciipennis Dodd. Dodd, 1924. Transactions and Proceedings of the Royal Society of South Australia 48: 172.

?Pseudanogmus fasciipennis Dodd. Hawkins, 1943. Annals and Magazine of Natural History, London (11)9(60): 881.

\section{ENCYRTIDAE}

\section{TETRACTEMINAE}

\section{Anusia viridiflava Dodd}

Anusia viridiflava Dodd, 1924. Transactions and Proceedings of the Royal Society of South Australia 48: 165.

Anusia viridiflava Dodd. Hawkins, 1943. Annals and Magazine of Natural History, London (11)9(60): 881.

\section{ENCYRTINAE}

Litomastix sp.

Litomastix sp. Holloway, 1977a. Lepidoptera of Norfolk Island, p. 282. 
Metaphycus sp.

Metaphycus sp. near lounsburyi (Howard). Hawkins, 1943. Annals and Magazine of Natural History, London (11)9(60): 881 .

Tachinaephagus sp.

Tachinaephagus sp. Ferrar, Standfast \& Dyce, 1975. Journal of the Australian entomological Society 14: 11.

\section{APHILINIDAE}

Aphelinus sp.

Aphelinus sp. (near dies Girault, pax Girault and nox Girault). Dodd, 1924. Transactions and Proceedings of the Royal Society of South Australia 48: 165.

Aphelinus sp. (near dies Girault, pax Girault and nox Girault) Hawkins, 1943. Annals and Magazine of Natural History, London (11)9(60): 881.

\section{EULOPHIDAE}

\section{EULOPHINAE}

Pnigalio norfolcensis (Dodd)

Sympiesomorpha norfolcensis Dodd, 1924. Transactions and Proceedings of the Royal Society of South Australia 48: 173.

Sympiesomorpha norfolcensis Dodd. Hawkins, 1943. Annals and Magazine of Natural History, London (11)9(60): 881.

\section{CHRYSIDOIDEA}

\section{SCOLEBYTHIDAE}

Ycaploca evansi Nagy

Ycaploca evansi Nagy. Naumann, 1990. Australian entomological Magazine 17(1): 20, fig. 15.

\section{DRYINIDAE}

Dryinid sp.

Dryinid sp. Naumann, 1990. Australian entomological Magazine 17(1): 22.

\section{BETHYLIDAE}

\section{PRISTOCERINAE}

Apenesia sp.

Apenesia sp. Naumann, 1990. Australian entomological Magazine 17(1): 22, fig. 13.

\section{EPYRINAE}

\section{?Lepidosternops sp.}

?Lepidosternops sp. Naumann, 1990. Australian entomological Magazine 17(1): 22, fig. 13.

Rhabdepyrus sp.

Rhabdepyrus sp. Naumann, 1990. Australian entomological Magazine 17(1): 22, fig. 14.

\section{Scleroderma norfolcensis Dodd}

Sclerodermus norfolcensis Dodd, 1924. Transactions and Proceedings of the Royal Society of South Australia 48: 184.

Sclerodermus norfolcensis Dodd. Hawkins, 1943. Annals and Magazine of Natural History, London (11)9(60): 883.

Sclerodermus norfolcensis Dodd. Turner, Smithers \& Hoogland, 1968. The Conservation of Norfolk Island, p. 40.

Sclerodermus norfolcensis Dodd. Naumann, 1990. Australian entomological Magazine 17(1): 22, fig. 21.

\section{BETHYLINAE}

Goniozus sp.

Goniozus sp. Naumann, 1990. Australian entomological Magazine 17(1): 22, fig. 22.

Sierola sp.

Sierola sp. Dodd, 1924. Transactions and Proceedings of the Royal Society of South Australia 48: 186.

Sierola sp. Dodd. Hawkins, 1943. Annals and Magazine of Natural History, London (11)9(60): 883.

Sierola sp. Naumann, 1990. Australian entomological Magazine 17(1): 22, fig. 20.

\section{CHRYSIDIDAE}

\section{CHRYSIDINAE}

Primeuchroeus biroi (Mocsáry)

Primeuchroeus biroi (Mocsáry). Naumann, 1990. Australian entomological Magazine 17(1): 22.

\section{VESPOIDEA}

\section{TIPHIIDAE}

Ariphron bicolor Erichson

Ariphron bicolor Erichson. Naumann, 1990. Australian entomological Magazine 17(1): 22.

\section{VESPIDAE}

\section{VESPINAE}

Vespula germanica (Fabricius)

Vespula germanica (Fabricius). Naumann, 1990. Australian entomological Magazine 17(1): 22.

\section{FORMICIDAE}

\section{PONERINAE}

Amblypone australis Erichson

Amblypone australis cephalotes Smith var. norfolkensis Wheeler, 1927a. Proceedings of the American Academy of Arts and Sciences 62: 15.

Amblypone australis cephalotes Smith var. norfolkensis Wheeler. Wheeler, 1927b. Proceedings of the American Academy of Arts and Sciences 62: 127, 129.

Amblypone australis cephalotes Smith var. norfolkensis Wheeler. Wheeler, 1935. Occasional Papers of the B.P. Bishop Museum 11(11): 9.

Amblypone australis cephalotes Smith var. norfolkensis Wheeler. Donisthorpe, 1941. Entomologist's monthly Magazine 77: 90.

Amblypone australis cephalotes Smith var. norfolkensis Wheeler. Hawkins, 1943. Annals and Magazine of Natural History, London (11)9(60): 882.

Amblypone australis cephalotes Smith. Turner, Smithers \& Hoogland, 1968. The Conservation of Norfolk Island, p. 40.

Amblypone australis Erichson. Holloway, 1977a. Lepidoptera of Norfolk Island, p. 282.

\section{Hypoponera punctatissima (Roger)}

Ponera mina Wheeler, 1927b. Proceedings of the American Academy of Arts and Sciences 62: 127, 131, fig. 2.

Ponera mina Wheeler. Wheeler, 1935. Occasional Papers of the B.P. Bishop Museum 11(11): 13.

Ponera mina Wheeler. Donisthorpe, 1941. Entomologist's monthly Magazine 77: 90. 
Ponera mina Wheeler. Hawkins, 1943. Annals and Magazine of Natural History, London (11)9(60): 882.

Hypoponera mina (Wheeler). Holloway, 1977a. Lepidoptera of Norfolk Island, p. 282.

Hypoponera punctatissima (Roger) Holloway, 1977a. Lepidoptera of Norfolk Island, p. 282.

Hypoponera mina (Wheeler). Taylor \& Brown, 1985. Zoological Catalogue of Australia 2: 31.

Ponera leae Forel

Ponera leae oculata Wheeler, 1927b. Proceedings of the American Academy of Arts and Sciences 62: 127, 130, fig. 1, (not P. oculata Smith).

Ponera leae norfolkensis Wheeler, 1935. Occasional Papers of the B.P. Bishop Museum 11(11): 13.

Ponera leae oculata Wheeler. Donisthorpe, 1941. Entomologist's monthly Magazine 77: 90.

Ponera leae oculata Wheeler. Hawkins, 1943. Annals and Magazine of Natural History, London (11)9(60): 882.

Ponera leae ovulata Wheeler. Turner, Smithers \& Hoogland, 1968. The Conservation of Norfolk Island, p. 40, (misprint of oculata).

Ponera norfolkensis Wheeler. Taylor, 1960. Pacific Science 14(2): 179.

Ponera leae Forel. Taylor, 1967. Pacific Insects Monographs 13: 88 , figs. $78-82$.

Ponera leae Forel. Taylor \& Brown, 1985. Zoological Catalogue of Australia 2: 38 .

\section{MYRMICINAE}

Cardiocondyla emeryi (Forel)

Cardiocondyla nuda nereis Wheeler, 1927b. Proceedings of the American Academy of Arts and Sciences 62: 127, 140.

Cardiocondyla nuda nereis Wheeler. Wheeler, 1935. Occasional Papers of the B.P. Bishop Museum 11(11): 21.

Cardiocondyla nuda nereis Wheeler. Donisthorpe, 1941. Entomologist's monthly Magazine 77: 90.

Cardiocondyla nuda nereis Wheeler. Hawkins, 1943. Annals and Magazine of Natural History, London (11)9(60): 883.

Cardiocondyla nuda (Mayr). Holloway, 1977a. Lepidoptera of Norfolk Island, p. 282.

Cardiocondyla nuda (Mayr). Taylor \& Brown, 1985. Zoological Catalogue of Australia 2: 55.

Monomorium sanguinolentum Wheeler

Monomorium (Notomyrmex) sanguinolentum Wheeler, 1927b. Proceedings of the American Academy of Arts and Sciences 62: 127, 135, fig. 4.

Monomorium (Notomyrmex) sanguinolentum Wheeler. Wheeler, 1935. Occasional Papers of the B.P. Bishop Museum 11(11): 25.

Monomorium (Notomyrmex) sanguinolentum Wheeler. Donisthorpe, 1941. Entomologist's monthly Magazine 77: 90.

Monomorium (Notomyrmex) sanguinolentum Wheeler. Hawkins, 1943. Annals and Magazine of Natural History, London (11)9(60): 882.

Monomorium sanguinolentum Wheeler. Turner, Smithers \& Hoogland, 1968. The Conservation of Norfolk Island, p. 40.

Chelaner sanguinolentus (Wheeler). Taylor \& Brown, 1985. Zoological Catalogue of Australia 2: 58.

Monomorium (Lampromyrmex) laeve Mayr

Monomorium (Lampromyrmex) laeve fraterculus Santschi. Wheeler, 1927b. Proceedings of the American Academy of Arts and Sciences 62: 127, 140.
Monomorium (Lampromyrmex) laeve fraterculus Santschi. Wheeler, 1935. Occasional Papers of the B.P. Bishop Museum 11(11): 26.

Monomorium (Lampromyrmex) laeve fraterculus Santschi. Donisthorpe, 1941. Entomologist's monthly Magazine 77: 90.

Monomorium (Lampromyrmex) laeve fraterculus Santschi. Hawkins, 1943. Annals and Magazine of Natural History, London (11)9(60): 882.

Pheidole vigilans (F. Smith)

Pheidole ampla norfolkensis Wheeler, 1927b. Proceedings of the American Academy of Arts and Sciences 62: 127, 134, fig. 3.

Pheidole (Pheidole) ampla norfolkensis Wheeler. Wheeler, 1935. Occasional Papers of the B.P. Bishop Museum 11(11): 17.

Pheidole (Pheidole) ampla norfolkensis Wheeler. Donisthorpe, 1941. Entomologist's monthly Magazine 77: 90.

Pheidole (Pheidole) ampla norfolkensis Wheeler. Hawkins, 1943. Annals and Magazine of Natural History, London (11)9(60): 882.

Pheidole ampla norfolkensis Wheeler. Turner, Smithers \& Hoogland, 1968. The Conservation of Norfolk Island, p. 40.

Pheidole vigilans (F. Smith). Taylor \& Brown, 1985. Zoological Catalogue of Australia 2: 79.

Oligomyrmex norfolkensis Donisthorpe

Oligomyrmex manni norfolkensis Donisthorpe, 1941. Entomologist's monthly Magazine 77: 92.

Oligomyrmex manni norfolkensis Donisthorpe. Hawkins, 1943. Annals and Magazine of Natural History, London (11)9(60): 882.

Oligomyrmex manni Donisthorpe. Turner, Smithers \& Hoogland, 1968. The Conservation of Norfolk Island, p. 40.

Oligomyrmex norfolkensis Donisthorpe. Taylor \& Brown, 1985. Zoological Catalogue of Australia 2: 72.

Strumigenys perplexa (F. Smith)

Strumigenys leae Forel. Wheeler, 1927b. Proceedings of the American Academy of Arts and Sciences 62: 127, 146, fig. 8.

Strumigenys leae Forel. Donisthorpe, 1941. Entomologist's monthly Magazine 77: 90.

Strumigenys leae Forel. Hawkins, 1943. Annals and Magazine of Natural History, London (11)9(60): 883.

Strumigenys perplexa (F. Smith). Taylor \& Brown, 1985. Zoological Catalogue of Australia 2: 88.

Strumigenys perplexa (F. Smith). Holloway, 1977a. Lepidoptera of Norfolk Island, p. 282.

Tetramorium antipodum Wheeler

Tetramorium antipodum Wheeler, 1927b. Proceedings of the American Academy of Arts and Sciences 62: 127, 143.

Tetramorium antipodum Wheeler. Donisthorpe, 1941. Entomologist's monthly Magazine 77: 90.

Tetramorium antipodum Wheeler. Hawkins, 1943. Annals and Magazine of Natural History, London (11)9(60): 883.

Tetramorium antipodum Wheeler. Turner, Smithers \& Hoogland, 1968. The Conservation of Norfolk Island, p. 40.

Tetramorium guineense (Fabricius)

Tetramorium guineense (Fabricius). Wheeler, 1927b. Proceedings of the American Academy of Arts and Sciences 62: 127, 143.

Tetramorium guineense (Fabricius). Wheeler, 1935. Occasional Papers of the B.P. Bishop Museum 11(11): 30.

Tetramorium guineense (Fabricius). Donisthorpe, 1941. Entomologist's monthly Magazine 77: 90.

Tetramorium guineense (Fabricius). Hawkins, 1943. Annals and Magazine of Natural History, London (11)9(60): 883. 
Tetramorium guineense (Fabricius). Holloway, 1977a. Lepidoptera of Norfolk Island, p. 282.

\section{DOLICHODERINAE}

Iridomyrmex albitarsus Wheeler

Iridomyrmex albitarsus Wheeler, 1927b. Proceedings of the American Academy of Arts and Sciences 62: 127, 147, fig. 9.

Iridomyrmex albitarsus Wheeler. Wheeler, 1935. Occasional Papers of the B.P. Bishop Museum 11(11): 34.

Iridomyrmex albitarsus Wheeler. Donisthorpe, 1941. Entomologist's monthly Magazine 77: 90.

Iridomyrmex albitarsus Wheeler. Hawkins, 1943. Annals and Magazine of Natural History, London (11)9(60): 883.

Iridomyrmex albitarsus Wheeler. Turner, Smithers \& Hoogland, 1968. The Conservation of Norfolk Island, p. 40.

Iridomyrmex albitarsus Wheeler. Taylor \& Brown, 1985. Zoological Catalogue of Australia 2: 96.

\section{FORMICINAE}

Paratrechina (Nylanderia) obscura Mayr

Paratrechina (Nylanderia) obscura Mayr. Donisthorpe, 1941. Entomologist's monthly Magazine 77: 90.

Paratrechina (Nylanderia) obscura Mayr. Hawkins, 1943. Annals and Magazine of Natural History, London (11)9(60): 883.

Paratrechina (Nylanderia) vaga Forel

Paratrechina (Nylanderia) vaga Forel. Wheeler, 1927b. Proceedings of the American Academy of Arts and Sciences 62: 127, 150.

Nylanderia vaga Forel. Wheeler, 1935. Occasional Papers of the B.P. Bishop Museum 11(11): 50.

Paratrechina (Nylanderia) vaga Forel. Donisthorpe, 1941. Entomologist's monthly Magazine 77: 90.

Paratrechina (Nylanderia) vaga Forel. Hawkins, 1943. Annals and Magazine of Natural History, London (11)9(60): 883 .

\section{SPHECOIDEA}

\section{SPHECIDAE}

\section{LARRINAE}

Liris festinans (Smith)

Liris sp. Holloway, 1977a. Lepidoptera of Norfolk Island, p. 282.

Liris festinans (Smith). Naumann, 1990. Australian entomological Magazine 17(1): 23, figs. 3, 4.

Pison caliginosum Turner

Pison caliginosum Turner. Naumann, 1990. Australian entomological Magazine 17(1): 24, fig. 19.

\section{Pison glabrum Kohl}

Pison glabrum Kohl. Naumann, 1990. Australian entomological Magazine 17(1): 24, fig. 8.

Pison marginatum Smith

Pison marginatum Smith. Naumann, 1990. Australian entomological Magazine 17(1): 25, figs. 10, 12.

Pison spinolae Shuckard

Pison spinolae Shuckard. Hawkins, 1943. Annals and Magazine of Natural History, London (11)9(60): 883.

Pison spinolae Shuckard. Naumann, 1990. Australian entomological Magazine 17(1): 24, figs. 1, 7, 18.
Pison (Pison) spinolae Shuckard. Cardale, 1985. Zoological Catalogue of Australia 2: 262.

Pison westwoodi Shuckard

Pison westwoodi Shuckard. Naumann, 1990. Australian entomological Magazine 17(1): 24, figs. 2, 5, 6, 9, 11.

\section{APOIDEA}

\section{COLLETIDAE}

HYLAEINAE

Hylaeus (Prosopistron) sp.

Hylaeus (Prosopistron) near asperithorax Rayment. Naumann, 1990. Australian entomological Magazine 17(1): 25, fig. 17.

\section{APIDAE}

APINAE

Apis mellifera Linnaeus

Apis mellifera Linnaeus. Holloway, 1977a. Lepidoptera of Norfolk Island, p. 282.

Apis mellifera Linnaeus. Naumann, 1990. Australian entomological Magazine 17(1): 25, fig. 16. 


\section{Bibliography of Norfolk Island Insects}

Ackery, P.R., \& R.I. Vane-Wright, 1984. Milkweed Butterflies, their cladistics and biology. i-ix, 425 pp., 25 text figs., 73 black and white plates, coloured plates I-XII. British Museum (Natural History), London.

Alexander, C.P., 1922. Undescribed crane-flies (Tanyderidae and Tipulidae) in the South Australian Museum. Records of the South Australian Museum 2: 223-270.

Anonymous, 1984. Plan of Management. Norfolk Island National Park. Plan of Management of Norfolk Island Botanical Gardens. 8 pp., 112 pp. Australian National Parks and Wildlife Service, Canberra.

Anonymous, 1996. Recent Sightings. Norfolk Nature Notes 12(2): 7.

Bates, F., 1873. Transactions of the entomological Society of London 1873: 371.

Belkin, J.N., 1962. Mosquitoes of the South Pacific. xii, 608 pp. University of California Press. Berkeley. (Vol. 1. Pp. 18, 197).

Ben-Dov, Y., 1993. A systematic catalogue of the soft scale insects of the world. Fauna and Flora Handbook No. 9, ixxviii, 536 pp. Sandhill Crane Press, Gainesville, Florida.

Best, A.D.W., 1966. The Journal of Ensign Best 1837-1843. Edited with an Introduction and Notes by Nancy M. Taylor. Turnbull Library Monograph No. 2. Government Printer. Wellington. 466 pp., illustr. (See Iredale, T., \& G. Whitley, 1969. Proceedings of the Royal zoological Society of New South Wales 1967-1968: 32-37). (The beetle mentioned by Best is Schizorhina bestii Westwood).

Bickel, D.J., 1986. Thrypticus and an allied new genus, Corindia, from Australia (Diptera: Dolichopodidae). Records of the Australian Museum 38: 135-151.

Bickel, D.J., 1994. The Australian Sciapodinae (Diptera: Dolichopodidae), with a Review of the Oriental and Australasian Faunas, and a World Conspectus of the Subfamily. Records of the Australian Museum, Supplement 21: 1-394, 130 figs.

Bickel, D.J., \& C.E. Dyte, 1989. Dolichopodidae. In: N.L. Evenhuis (ed.). Catalog of the Diptera of the Australasian and Oceanian Regions. Bishop Museum Special Publication 86: 393-418.

Bock, I.R., 1986. The Drosophilidae (Insecta: Diptera) of Norfolk Island. Australian Journal of Zoology 34: 305-313, 6 figs.

Bolton, B., 1995. A New General Catalogue of the Ants of the World. 504 pp. Harvard University Press, Cambridge, Massachusetts. (This work has not been seen).

Boucek, Z., 1988. Australian Chalcidoidea (Hymenoptera). A systematic revision of genera of fourteen families, with a reclassification of species. 832 spp., 1328 figs. C.A.B. International. Wallingford, England.

Bradley, J.D., 1956. Records and descriptions of Microlepidoptera from Lord Howe Island and Norfolk Island collected by the British Museum (Natural History) Rennell Island Expedition, 1953. Bulletin of the British Museum of Natural History (Entomology) 4(4): 145-164, 26 figs.

Bradley, J.D., 1982. New species of Microlepidoptera from Norfolk Island. Journal of Natural History 16(3): 367-379, 30 figs.

Breuning, S., 1948. Nouvelles formes de Longicornes du Musée de Stockholm. Arkiv f. Zoologie 39(A)(6): 1-68.

Breuning, S., 1962. Nouveaux Lamiaires du British Museum (Natural History) (Col. Cerambycidae). Annals and Magazine of Natural History, London (13): 5: 233-241.
Calder, A., 1996. Siphonaptera. In: A. Wells (ed.). Zoological Catalogue of Australia. Vol. 28. Pp. 136-181, 185-197, 222226 (index). CSIRO Publishing, Australia.

Cardale, J., 1985. Vespoidea and Sphecoidea. In: D.W. Walton (ed.). Zoological Catalogue of Australia. Vol. 2. Pp. 150303, 349-381 (index). Australian Government Publishing Service, Canberra.

Cassis, G., \& G.F. Gross, 1995. Hemiptera: Heteroptera (Coleorrhyncha to Cimicomorpha). In: W.W.K. Houston and G.V. Maynard (eds). Zoological Catalogue of Australia. Vol. 27.3A. Pp. xv, pp. 1-506. CSIRO, Melbourne, Australia.

Cassis, G., \& T.A. Weir, 1992a. Aphodiinae. In: W.W.K. Houston (ed.). Zoological Catalogue of Australia. Vol. 9. Pp. 81-105, 465-543 (index). Australian Government Publishing Service, Canberra.

Cassis, G., \& T.A. Weir, 1992b. Scarabaeinae In: W.W.K. Houston (ed.). Zoological Catalogue of Australia. Vol. 9. Pp. 106-173, 465-543 (index). Australian Government Publishing Service, Canberra.

Cassis, G., \& T.A. Weir, 1992c. Dynastinae. In: W.W.K. Houston (ed.). Zoological Catalogue of Australia. Vol. 9. Pp. 383425, 465-543 (index). Australian Government Publishing Service, Canberra.

Cassis, G., \& T.A. Weir, 1992d. Cetoniinae. In: W.W.K. Houston (ed.). Zoological Catalogue of Australia. Vol. 9. Pp. 426454, 465-543 (index). Australian Government Publishing Service, Canberra.

Chopard, L., 1951. A revision of the Australian Grylloidea. Records of the South Australian Museum 9: 397-533, 89 figs.

Common, I.F.B., 1958. The Australian cutworms of the genus Agrotis (Lepidoptera: Noctuidae). Australian Journal of Zoology 6: 69-88, pls. 1-3.

Common, I.F.B., 1982. Two species of Tracholena Common (Lepidoptera: Tortricidae) feeding on Araucaria in Queensland and Norfolk Island. Journal of the Australian entomological Society. 21(3): 221-224, 10 figs.

Common, I.F.B., 1990. Moths of Australia. 535 pp., 129 figs., 32 pls. Melbourne University Press. Australia.

Common, I.F.B., \& D.F. Waterhouse, 1972. Butterflies of Australia. i-xii, 498 pp., 25 text figs., 41 pls. Angus and Robertson. Sydney.

Common, I.F.B., \& D.F. Waterhouse, 1981. Butterflies of Australia. i-xiv, 682 pp., 25 text figs., 49 pls. Angus and Robertson. Sydney.

Common, I.F.B., \& D.F. Waterhouse, 1982. Butterflies of Australia. Field Edition. i-xiv, 434 pp., 25 text figs., pls. 129 , pls. I-XX. (This is an abridged version of Common \& Waterhouse, 1981).

Cook, E.F., 1989. Scatopsidae. In: N.L. Evenhuis (ed.). Catalog of the Diptera of the Australasian and Oceanian Regions. Bishop Museum Special Publication 86: 182-185.

Crosskey, R.W., 1989. Simuliidae. In: N.L. Evenhuis (ed.). Catalog of the Diptera of the Australasian and Oceanian Regions. Bishop Museum Special Publication 86: 221-225.

Crotch, G.R., 1874. A revision of the Coleopterous family Coccinellidae. Janson. London.

CSIRO (ed.), 1991. The Insects of Australia. A textbook for students and research workers. i-xiii, $560+600$ pp., 2 vols. Melbourne University Press, Carlton.

D'Abrera, B., 1971. Butterflies of the Australian Region. 415 pp. Lansdowne Press, Melbourne. 
Deane, C., 1931. Trichopterygidae of Australia and adjacent Islands. Descriptions of five new genera and twenty new species. Proceedings of the Linnean Society of New South Wales 56: 227-242, 23 figs.

Distant, W.L., 1892. On some undescribed Cicadidae, with synonymical notes. Annals and Magazine of Natural History, London (6)9: 313-327.

Distant, W.L., 1906. A Synonymic Catalogue of the Homoptera. Part 1. Cicadidae. 207 pp. British Museum, London.

Dodd, A.P., 1924. Chalcidoidea and Proctotrupoidea from Lord Howe and Norfolk Islands, with descriptions of new genera and species. Transactions and Proceedings of the Royal Society of South Australia 48: 162-186.

Donisthorpe, H., 1941. The ants of Norfolk Island. Entomologist's monthly Magazine 77: 90-93.

Donovan, E., 1805. An epitome of the natural history of the Insects of New Holland, New Zealand, New Guinea, Otaheite, and other islands in the Indian, Southern, and Pacific Oceans... etc. i-iv, 41 col. pls. with associated text. Privately published. London.

Duffels, J.P., \& P.A. van der Laan, 1985. Catalogue of the Cicadoidea (Homoptera, Auchenorrhyncha) 1956-1980. Series Entomologica 34. Pp. i-xiv, 1-414. W. Junk. Dordrecht.

Dugdale, J.S., 1972. Genera of New Zealand Cicadidae (Homoptera). New Zealand Journal of Science 14(4): 856882,31 figs.

Dumbleton, L.J., 1969. New Simuliidae (Diptera) from New Caledonia and Norfolk Island. New Zealand Journal of Science 12: 213-222, 12 figs.

Early, J.W., G.R. Parrish \& P.A. Ryan, 1995. An invasion of Australian Blue Moon and Blue Tiger butterflies (Lepidoptera: Nymphalidae) in New Zealand. Records of the Auckland Institute and Museum 32: 45-53, 5 figs.

Evans, B., 1977. Hypolimnas misippus (L.) and Euploea core corinna (W. S. Macleay) (Lepidoptera: Nymphalidae) from Norfolk Island. Australian entomological Magazine 3(6): 106.

Evans, B., 1981. Establishment of the Lesser Wanderer, Danaus chrysippus petilia (Stoll) (Lepidoptera: Nymphalidae) on Norfolk Island. Australian entomological Magazine 8(4): 54.

Evans, B., 1984. Unusual butterfly record. Norfolk Nature Notes 1(2): 4

Evans, B., 1995. "Update". Norfolk Nature Notes 11(3): 396. (Tirumala hamata).

Evenhuis, N.L. (ed.), 1989. Catalog of the Diptera of the Australasian and Oceanian Regions. Bishop Museum Special Publication 86: 1155.

Evenhuis, N.L., 1989a. Platystomatidae. In: N.L. Evenhuis (ed.). Catalog of the Diptera of the Australasian and Oceanian Regions. Bishop Museum Special Publication 86: 482-497.

Evenhuis, N.L., 1989b. Gasterophilidae. In: N.L. Evenhuis (ed.). Catalog of the Diptera of the Australasian and Oceanian Regions. Bishop Museum Special Publication 86: 720.

Evenhuis, N.L., \& S.M. Gon III, 1989. Culicidae. In: N.L. Evenhuis (ed.). Catalog of the Diptera of the Australasian and Oceanian Regions. Bishop Museum Special Publication 86: 191-218.

Evenhuis, N.L., \& T. Okada, 1989. Drosophilidae. In: N.L. Evenhuis (ed.). Catalog of the Diptera of the Australasian and Oceanian Regions. Bishop Museum Special Publication 86: 609-638.

Evenhuis, N.L., \& T. Okadame, 1989. Lauxaniidae. In: N.L. Evenhuis (ed.). Catalog of the Diptera of the Australasian and Oceanian Regions. Bishop Museum Special Publication 86: $576-589$.
Fabricius, J.C., 1792. Entomologia systematica emendata et aucta secumdum classes, ordines, genera, species adjectis synonimis locis, observationibus, descriptionibus. 4 vols., suppl., index. Hafniae. (Lethrus aeneus Col., Vol. 1, pt. 1, p. 2).

Ferrar, P., H.A. Standfast \& A.L. Dyce, 1975. A survey of bloodsucking and synanthropic Diptera and dung insects on Norfolk Island, South Pacific. Journal of the Australian entomological Society 14: 7-13, 1 fig.

Fleming, C.A., 1973. The Kermadec Islands Cicada and its relatives (Hemiptera, Homoptera). New Zealand Journal of Science 16(2): 315-322.

Froggatt, W.W., 1896. Australian Termitidae. Part II. Proceedings of the Linnean Society of New South Wales 21(4): 510-552, pls xxxv-xxxvi.

Gaedike, R., 1979. Katalog der Epermeniidae der Welt. Beiträge zur Entomologie 29: 271-288, 11 figs.

Ghauri, M.S.K., 1966. Revision of the genus Orosius Distant (Homoptera: Cicadelloidea). Bulletin of the British Museum of Natural History (Entomology) 18: 231-252.

Goding, F.W., \& W.W. Froggatt, 1904. Monograph of the Australian Cicadidae. Proceedings of the Linnean Society of New South Wales 29: 561-668, pls. XVIII, XIX.

Greenslade, P., 1994. Collembola. In: W.W.K. Houston (ed.). Zoological Catalogue of Australia. Vol. 22. Pp. 19-138, 165182 (index).

Greenslade, P., \& L. Deharvheng, 1990. Australian species of the genus Australonura (Collembola: Neanuridae). Invertebrate Taxonomy 3(5): 565-593, 29 figs.

Gressitt, L., 1960. Papuan-West Polynesian Hispine beetles (Chrysomelidae). Pacific Insects 2: 1-90, 24 figs.

Gross, G., 1975. A revision of the Pentatomidae (HemipteraHeteroptera) of the Rhynchocoris group from Australia and adjacent areas. Records of the South Australian Museum 17(6): 1-167, 64 figs.

Hawkins, C.N., 1943. The Insects of Norfolk Island, including a preliminary report on a recent collection. Annals and Magazine of Natural History, London (11) 9(60): 865-902. (Covers earlier literature).

Hill, G.F., 1926. Australian Termites (Isoptera). Notes on Stolotermes, Calotermes, and Coptotermes with descriptions of new species. Proceedings of the Royal Society of Victoria 38(N.S.): 196.

Hill, G.F., 1942. Termites (Isoptera) of the Australian Region. CSIRO, Melbourne. 479 pp., 353 figs, 24 pls.

Holdhaus, K., 1926-1929. In: C. Schröder. Handbuch der Entomologie. Gustav Fischer. Jena. (No additional records of species but discusses geographical distribution of some Norfolk Island species).

Hollis, D., 1968. A revision of the genus Aiolopus Fieber (Orthoptera: Acrididae). Bulletin of the British Museum of Natural History (Entomology) 22(7): 309-355.

Holloway, J.D., 1976a. Norfolk Island Philatelic Bulletin 1976(2), 4 pp. (Published August, 1976).

Holloway, J.D., 1976b. Norfolk Island Philatelic Bulletin 1976(3), 4 pp. (Published December, 1976).

Holloway, J.D., 1977a. The Lepidoptera of Norfolk Island, their biogeography and ecology. Series Entomologica 13, i-vi, 291 pp., 29 pls., 140 figs. Junk. The Hague.

Holloway, J.D., 1977b. Norfolk Island Philatelic Bulletin 1977(1), 4 pp. (Published February, 1977). [Holloway, J.D., (1977). Norfolk Island Philatelic Bulletin 1977(2), 4 pp., published April, 1977, not cited in the current work.]

Holloway, J.D., 1979. A survey of the Lepidoptera, biogeography and ecology of New Caledonia. Series Entomologica 15, ixii, 588 pp. 87 pls., 153 figs. Junk. The Hague. 
Holloway, J.D., 1982. Further notes on the Lepidoptera of Norfolk Island with particular reference to migrant species. Journal of Natural History 16(3): 351-365, illustr.

Holloway, J.D., 1984. Lepidoptera records and notes from Norfolk Island, 1981-1983. Proceedings and Transactions of the British entomological and natural History Society 17(3): 67-70.

Holloway, J.D., \& J.V. Peters, 1976. The butterflies of New Caledonia and the Loyalty Islands. Journal of Natural History 10: 273-318, 36 figs.

Houston, K.J., 1983. Redescription of Stethorus obscuripennis (Lea) (Coleoptera: Coccinellidae) from Norfolk Island. Journal of the Australian entomological Society 22(3): 185187 , figs. $1-8$.

Houston, W.W.K., \& J.A.L. Watson, 1988. Odonata. In: W.W.K. Houston (ed.). Zoological Catalogue of Australia. Vol. 6. Pp. 33-132, 289-299 (index). Australian Government Publishing Service, Canberra.

Iredale, T., \& G. Whitley, 1969. Captain Abel D.W. Best (18161845), a soldier-naturalist and his diaries. Proceedings of the Royal Zoological Society of New South Wales 1967-1968 (1969): 32-37. (Records that the beetle mentioned by Best is Schizorhina bestii Westwood).

Karny, H.H., 1925. On a new Phloeothrips (Thysanoptera) from Norfolk Island. Records of the South Australian Museum 3: 37-39, fig. 17.

Kimmins, D.E., 1941. Notes on the Odonata and Neuroptera of Norfolk Island. Entomologist's monthly Magazine 77: 134136.

Kimmins, D.E., 1952. Some new Australian Chrysopidae. Annals and Magazine of Natural History, London (12)5: 69-81, 10 figs.

Kirby, W.F., 1890. A revision of the Forficulidae, with descriptions of new species in the British Museum. Journal of the Linnean Society of London 23: 502-531, 12 figs.

Knight, W.J., 1976. The leaf hoppers of Lord Howe, Norfolk, Kermadec and Chatham Islands and their relationship to the fauna of New Zealand (Homoptera: Cicadellidae). New Zealand Journal of Zoology 3: 89-98, 4 figs.

Kormilev, N.A., 1966. Aradidae in the South Australian Museum, Adelaide (Hemiptera-Heteroptera). Records of the South Australian Museum 15(2): 275-307, 31 figs.

Kurahashi, H., 1971. The tribe Calliphorini from Australia and Oriental Region. II. Calliphora-group (Diptera: Calliphoridae). Pacific Insects 13(1): 141-204, 168 figs.

Kurahashi, H., 1989. Calliphoridae. In: N.L. Evenhuis (ed.). Catalog of the Diptera of the Australasian and Oceanian Regions. Bishop Museum Special Publication 86: 702-718.

Lawrence, J.F., T.A. Wier \& J.E. Pyke, 1987. Haliplidae, Hygrobiidae, Noteridae, Dytiscidae and Gyrinidae. In: D.W. Walton (ed.). Zoological Catalogue of Australia. Vol. 4. Pp. 360-366, 369-443 (index). Melbourne. CSIRO Publishing, Australia.

Lea, A.M., 1913. Descriptions of Australian Curculionidae, with notes on previously described species. Part XI. Transactions and Proceedings of the Royal Society of South Australia 37: 301-445.

Lea, A.M., 1915. Notes on Australian Eumolpides (Coleoptera, Chrysomelidae), with descriptions of new species. Transactions and Proceedings of the Royal Society of South Australia 39: 102-339, 173 figs.

Lea, A.M., 1916. Notes on some miscellaneous Coleoptera with descriptions of new species. Part II. Transactions and Proceedings of the Royal Society of South Australia 40: 272436, 158 figs.
Lea, A.M., 1917. Notes on some miscellaneous Coleoptera, with descriptions of new species. Part III. Transactions and Proceedings of the Royal Society of South Australia 41: 121322,4 pls.

Lea, A.M., 1923. On Australian Staphylinidae (Coleoptera). Transactions and Proceedings of the Royal Society of South Australia 47: 1-53.

Lea, A.M., 1924a. On Australian Histeridae (Coleoptera). Transactions of the entomological Society of London 57: 239 263, 30 figs.

Lea, A.M., 1924b. On Australian Anobiidae (Coleoptera). Transactions and Proceedings of the Royal Society of South Australia 48: 15-64, 42 figs.

Lea, A.M., 1925. On Australian Staphylinidae (Coleoptera). Part II. Transactions and Proceedings of the Royal Society of South Australia 49: 213-253.

Lea, A.M., 1926a. Notes on some miscellaneous Coleoptera, with descriptions of new species. Part VI. Transactions and Proceedings of the Royal Society of South Australia 50: 4584.

Lea, A.M., 1926b. On the genus Mandalotus (Coleoptera, Curculionidae). Records of the South Australian Museum 3(2): 147-193.

Lea, A.M., 1927. Descriptions of new species of Australian Coleoptera. Part xix. Proceedings of the Linnean Society of New South Wales 52(3): 354-377.

Lea, A.M., 1928a. Australian Curculionidae of the subfamilies Haplonycides and Cryptorhynchides. Transactions and Proceedings of the Royal Society of South Australia 52: 95164 , pls. VII-IX, 1 fig.

Lea, A.M., 1928b. Cryptorhynchides (Curculionidae) mostly from Australia. Records of the South Australian Museum 4(1): 49-90.

Lea, A.M., 1929. Notes on some miscellaneous Coleoptera, with descriptions of new species. Part VII. Transactions and Proceedings of the Royal Society of South Australia 53: 203244, 5 figs.

Lea, A.M., 1930. On Australian Coleoptera. Part VI. Records of the South Australian Museum 4(2): 243-273, 1 fig.

Lea, A.M., 1931. Notes on some miscellaneous Coleoptera, with descriptions of new species. Part VIII. Transactions and Proceedings of the Royal Society of South Australia 55: 3964, 32 figs.

Lopes, H. de S., 1989. Sarcophagidae. In: N.L. Evenhuis (ed.). Catalog of the Diptera of the Australasian and Oceanian Regions. Bishop Museum Special Publication 86: 721-732.

Marks, E.N., 1972. Mosquitoes of Norfolk Island. News Bulletin of the entomological Society of Queensland 87: 11-12.

Mathew, G.F., 1888. Life histories of Rhopalocera from the Australian Region. Transactions of the entomological Society of London 1881 (1): 137-188, pl. VI.

McKeown, K.G., 1938. Notes on Australian Cerambycidae. IV. Records of the Australian Museum 20(3): 200-216, 2 pls.

Metcalf, Z.P., 1963. General Catalogue of the Homoptera. Fascicle III, Cicadoidea, Part 2. Tibicinidae. Pp. i-vi, 1-492.

Meyrick, E., 1886. Descriptions of Lepidoptera from the South Pacific. Transactions of the entomological Society of London 1886: $189-296$.

Moore, B.P., 1985. The Carabidae of Norfolk Island. In: G.E. Ball (ed.). Taxonomy, Phylogeny and Zoogeography of Beetles and Ants: A Volume dedicated to the memory of Philip Jackson Darlington Jr. (1904-1983). W. Junk, Doordrecht, Netherlands. Pp. 237-256, 14 figs. (Series Entomologica) 3: 237-256, 14 figs.). 
Moore, B.P., 1992. The Carabidae of Lord Howe Island (Coleoptera: Carabidae). In: G.R. Noonan, G.E. Ball and N.E. Stork (eds). The Biogeography of Ground Beetles of Mountains and Islands. Intercept, Andover. England. i-vii., 256 pp. Pp. 159-173.

Moore, B.P., \& G. Cassis, 1992. Lucanidae. In: W.W.K. Houston (ed.). Zoological Catalogue of Australia. Vol. 9. Pp. 4-19, 465-543 (index). Australian Government Publishing Service, Canberra.

Moore, B.P., T.A. Weir \& J.E. Pyke, 1987. Rhysodidae and Carabidae. In: D.W. Walton (ed.). Zoological Catalogue of Australia. Vol. 4, pp. 20-320, 373-443 (index). Melbourne. CSIRO Publishing, Australia.

Morse, J.C., \& A. Neboiss, 1982. Triplectides of Australia (Insecta: Trichoptera: Leptoceridae). Memoirs of the national Museum of Victoria 43: 61-98, 100 figs. (Australian references to Triplectides cephalotes prior to 1982 are referable to $T$. australis).

Mosely, M.E., \& D.E. Kimmins, 1953. The Trichoptera (CaddisFlies) of Australia and New Zealand. 550 pp., 364 figs. London.

Moulds, M.S., 1990. Australian Cicadas. i-vii, 217 pp. New South Wales University Press. Sydney.

Mound. L.A., 1974. Spore-feeding Thrips (Phlaeothripidae) from leaf litter and dead wood in Australia. Australian Journal of Zoology, Supplementary Series. 27: 1-106.

Mound, L.A., 1996. Thysanoptera. In: A. Wells (ed.). Zoological Catalogue of Australia. Vol. 26, pp. 249-332, 337 (Appendix III), 397-414 (index). CSIRO Publishing, Melbourne. Australia.

Naumann, I., 1990. The aculeate wasps and bees (Hymenoptera) of Norfolk and Philip Islands. Australian entomological Magazine 17(1): 17-28, 22 figs.

Neboiss, A., 1967. The genera Paracalais gen. nov. and Austrocalais gen. nov. (Coleoptera: Elateridae). Proceedings of the Royal Society of Victoria 80: 259-287, 40 figs., pls. 43-46.

Neboiss, A., 1984. Distribution of Trichoptera in the SW Pacific area. Victorian Entomologist 14(2): 14-17. (General comments on distribution).

Nelson, B.C., 1969. Bird ectoparasites from Norfolk Island. Australian Zoologist 15(2): 199-200.

New, T.R., 1980. A revision of the Australian Chrysopidae (Insecta: Neuroptera). Australian Journal of Zoology, Supplementary Series 77: 1-143, 552 figs.

New, T.R., 1987a. The Neuroptera (Insecta) of Norfolk Island. Invertebrate Taxonomy 1(3): 257-268, 52 figs.

New, T.R., 1987b. A chrysopid (Neuroptera, Chrysopidae) with two spermathecae. Neuroptera International 4(3): 221-223, 5 figs.

New, T.R., 1996. Neuroptera. In: A. Wells (ed.). 1996. Zoological Catalogue of Australia. Vol 28. Pp. xiv, 1-104, 184, 199-216 (index).

Nielsen, E.S., E.D. Edwards \& T.V. Rangsi, 1996. Checklist of the Lepidoptera of Australia. Monographs on Australian Lepidoptera. Vol. 4. i-xiv, 529 pp. CSIRO Publishing, Collingwood. Australia.

Olliff, A.S., 1887. Notes and exhibits. Abstracts of Proceedings of the Linnean Society of New South Wales, 29th June, 1887: vii. [See also under Olliff (1888b) below.]

Olliff, A.S., 1888a. Report on a small zoological collection from Norfolk Island. Part IV. Insecta. Proceedings of the Linnean Society of New South Wales (2)2(4): 1001-1014.

Olliff, A.S., 1888b. Proceedings of the Linnean Society of New South Wales (2)2(2): 412. (This is the same as Olliff, 1887).

Olliff, A.S., 1889. Australian Butterflies. A brief account of the native families. Sydney. 48 pp., illustr.
Olliff, A.S., 1890. Additions to the insect fauna of Lord Howe Island and descriptions of two new Australian Coleoptera. Records of the Australian Museum 1: 72-76, pl. x.

Oosterbroek, P., 1989. Tipuloidea, Tipulidae. In: N.L. Evenhuis (ed.). Catalog of the Diptera of the Australasian and Oceanian Regions. Bishop Museum Special Publication 86: 53-116.

Otte, D., \& D.C.F. Rentz, 1985. The crickets of Lord Howe and Norfolk Islands (Orthoptera, Gryllidae). Proceedings of the Academy of Natural Sciences of Philadelphia 13: 79-101, 17 figs.

Palma, R.L., \& S.C. Barker, 1996. Phthiraptera. In: A. Wells (ed.). Zoological Catalogue of Australia. Vol. 26. Pp. 81247, 336 (Appendix III), 338-361 (Appendix IV), 373-396 (index). CSIRO Publishing, Melbourne. Australia.

Pitkin, L.M., 1980. A revision of the Pacific species of Conocephalus Thunberg (Orthoptera: Tettigoniidae). Bulletin of the British Museum of Natural History (Entomnology) 41(5): 315-355, 59 figs.

Pont, A.C., 1973a. Studies on Australian Muscidae (Diptera). IV. A revision of the subfamilies Muscinae and Stomoxyinae. Australian Journal of Zoology, Supplementary Series 21: 129296, 171 figs.

Pont, A.C., 1973b. Studies on Australian Muscidae (Diptera). V. Muscidae and Anthomyiidae from Lord Howe Island and Norfolk Island. Journal of the Australian entomological Society 12: 175-194, 18 figs.

Pont, A.C., 1977. A revision of Australian Fanniidae (Diptera: Calyptrata). Australian Journal of Zoology, Supplementary Series 51: 1-60.

Pont, A.C., 1989a. Anthomyiidae. In: N.L. Evenhuis (ed.). Catalog of the Diptera of the Australasian and Oceanian Regions. Bishop Museum Special Publication 86: 673-674.

Pont, A.C., 1989b. Muscidae. In: N.L. Evenhuis (ed.). Catalog of the Diptera of the Australasian and Oceanian Regions. Bishop Museum Special Publication 86: 675-699.

Pont, A.C., 1989c. Fanniidae. In: N.L. Evenhuis (ed.). Catalog of the Diptera of the Australasian and Oceanian Regions. Bishop Museum Special Publication 86: 700-701.

Pope, R.D., 1988. A revision of the Australian Coccinellidae (Coleoptera). Invertebrate Taxonomy 2: 633-735. 191 figs.

Poulton, E.B., 1924. Mimicry in the butterflies of Fiji considered... Transactions of the entomological Society of London 1923(34): 564-675, pls. xxix-liii.

Rainbow, W.J., 1907. A Guide to the Study of Australian Butterflies. 272 pp., 184 text figs., 19 plates, not numbered, frontis., pls. I-VI. T.C. Lothian. Melbourne.

Rentz, D.D.F., 1988. The orthopteroid insects of Norfolk Island, with descriptions of some related species from Lord Howe Island, South Pacific. Invertebrate Taxonomy 2: 1013-1077, 105 figs.

Roth, L.M., 1977. A Taxonomic Revision of the Panesthiinae of the World. I. The Panesthiinae of Australia (Dictyoptera: Blattaria: Blaberidae). Australian Journal of Zoology, Supplementary Series 48: 1-112, 51 figs.

Sakai, S., 1970. Dermapterorum Catalogus Praeliminaris. I. A Basic Survey for numerical taxonomy of the Carcinophoridae, Dermaptera of the World $91 \mathrm{pp}$.

Samuelson, G.A., 1973. Alticinae of Oceania (Coleoptera: Chrysomelidae). Pacific Insects Monographs 30: 1-165, 40 figs.

Schedl, K.E., 1972. Bark and Timber Beetles of the Pacific Islands. New Zealand Journal of Science 15(3): 265-272.

Schmidt, E., 1938. Check list of Odonata of Oceania. Annals of the entomological Society of America 31(3): 322-344. 
Schneider, M.A., \& D.K. McAlpine, 1979. Three new species of acalyptrate flies (Diptera: Lauxaniidae and Platystomatidae) from Norfolk Island. Australian entomological Magazine 6(4): 69-73, 4 figs.

Scott, A.W., 1890. Australian Lepidoptera with their transformations, by the late Alexander Walker Scott; with illustrations drawn from the life by his daughters, Harriet Morgan and Helena Forde. Vol. 2. Revised and edited by A. S. Olliff and Helena Forde. 36 pp., pls. X-XXI. Australian Museum, Sydney. (Vol. 2, pt. 1, p. 10 [footnote]).

Scott, A.W., 1893. Australian Lepidoptera with their transformations, by the late Alexander Walker Scott; with illustrations drawn from the life by his daughters, Harriet Morgan and Helena Forde. Vol. 2. Revised and edited by A. S. Olliff and Helena Forde. 36 pp., pls. X-XXI. Australian Museum, Sydney. (Vol. 2. pt. 4, pp. 27-36, pls. XIX-XXI. G. macleayanum p. 31, pl. XX).

Smith, G.B., 1988. New species of Trinemura Silvestri (Thysanura: Nicoletiidae) from Australia. Journal of the Australian entomological Society 27(1): 47-52.

Smithers, C.N., 1969. A note on migrations of Vanessa kershawi (McCoy) (Lepidoptera: Nymphalidae) in Australia, 19631968. Australian Zoologist 15(2): 188-194, 1 fig.

Smithers, C.N., 1970a. A note on the seasonal occurrence of some Norfolk Island butterflies. Proceedings of the Royal zoological Society of New South Wales 1968-1969: 46-47.

Smithers, C.N., 1970b. Norfolk Island Butterflies. 24 pp., 2 pls. Australian Entomological Press, Sydney.

Smithers, C.N., 1975. Melanitis leda bankia (Fabricius) (Lepidoptera: Nymphalidae) in Sydney and on Norfolk Island. Australian entomological Magazine 2(5): 110-111.

Smithers, C.N., 1976. A record of Aeshna brevistyla Rambur (Odonata: Aeshnidae) from Norfolk Island. Australian entomological Magazine 3(3): 57.

Smithers, C.N., 1977. The oak leaf-miner, Phyllonorycter messaniella (Zeller) (Lepidoptera: Gracillariidae), established on Norfolk Island. Australian entomological Magazine 4(1): 16.

Smithers, C.N., 1980. A redescription of Ectopsocus richardsi (Pearman) (Psocoptera: Ectopsocidae) based on Australian material. General and applied Entomology 12: 13-15, 5 figs.

Smithers, C.N., 1981. Synopsis of localities and key to the Psocoptera of Norfolk Island. Australian entomological Magazine 7(6): 85-88.

Smithers, C.N., 1986. Some new records of Psocoptera from Norfolk and Phillip Islands. Australian entomological Magazine 13(1): 33-34. (Incorrect spelling of Philip Island).

Smithers, C.N., 1994. Trogium evansorum sp.n. (Psocoptera: Trogiidae) a remarkable prognathous species from Norfolk Island. Australian Entomologist 21(4): 153-155, 10 figs.

Smithers, C.N., 1995. The first record of Tirumala hamata hamata (W. S. Macleay) (Lepidoptera: Nymphalidae), the Blue Tiger Butterfly on Norfolk Island. Norfolk Nature Notes 11(3): 395-396.

Smithers, C.N., 1996. Psocoptera. In: A. Wells (ed.). Zoological Catalogue of Australia. Vol. 26. Pp. 1-79, 333-372 (index). CSIRO Publishing, Melbourne. Australia.

Smithers, C.N., \& O.R. Evans, 1974. The reappearance of Anaphaeis java peristhene (Boisduval) (Lepidoptera: Pieridae) on Norfolk Island. Australian entomological Magazine 2(1): 9-11.

Smithers, C.N., \& J.V. Peters, 1969. The butterflies of Norfolk, Philip and Nepean Islands. Australian Zoologist 15(2): 185-187.

Smithers, C.N., \& I.W.B. Thornton, 1974. The Psocoptera (Insecta) of Norfolk Island. Records of the Australian Museum 29(8): 209-234, figs. 1-67.
Spencer, K., 1976. The Agromyzidae of New Zealand. Transactions of the Royal Society of New Zealand 6: 153 211, 101 figs.

Spencer, K., 1989. Agromyzidae. In: N.L. Evenhuis (ed.). Catalog of the Diptera of the Australasian and Oceanian Regions. Bishop Museum Special Publication 86: 538-547.

Tams, W.H.T., 1935. Insects of Samoa 3: 201, 256, 257. (See Hawkins 1943: 867 for content of Tams' comments).

Taylor, F.H., 1934. A Check List of the Culicidae of The Australian Region. Publication of the School of public Health and tropical Medicine, University of Sydney 1: 1-24, 1 map.

Taylor, R.W., 1960. Taxonomic notes on the ants Ponera leae Forel and Ponera norfolkensis (Wheeler) (Hymenoptera: Formicidae). Pacific Science. 14(2): 178-180, 1 fig.

Taylor, R.W., 1967. A monographic revision of the ant genus Ponera Latreille (Hymenoptera: Formicidae). Pacific Insects Monographs 13: 1-112, 87 figs.

Taylor, R.W., \& D.R. Brown, 1985. Hymenoptera: Formicoidea. In: D.W. Walton (ed.). Zoological Catalogue of Australia. Vol. 2, 1-149, 306-348 (index).

Tendeiro, J., 1972a. Estudos sobre os goniodideos (Mallophaga, Ischnocera) dos Columbiformes. VIII. Uma nova espécie para o género Nitzschiella n. sp. parasita da Hemiphaga novaeseelandiae spadicea (Latham). Rev. Cienc. Vet. (Lourenco Marques) (ser. A) 5: 1-15.

Tendeiro, J., 1972b. Estudos sobre os goniodideos. (Mallophaga, Ischnocera) dos Columbiformes. X. Descricao do género Patellinirmus nov. para tres espécies novas parasitas de columbideos do género Hemiphaga Bonaparte. Rev. Cienc. Vet. (Lourenco Marques) (ser. A) 5: 55-99.

Thornton, I.W.B., 1981. The systematics, phylogeny and biogeography of the psocopteran family Philotarsidae. Systematic Entomology 6: 413-452, 54 figs.

Tillyard, R.J., 1917. Odonata, Planipennia and Trichoptera from Lord Howe and Norfolk Islands. Proceedings of the Linnean Society of New South Wales 42(3): 529-544, 10 figs.

Tindale, N.B., 1923. On Australian Rhopalocera. Transactions and Proceedings of the Royal Society of South Australia 47: 342-354, text figs. A-F, pls. XXVIII-XXX.

Turner, A.J., 1917. On some moths from Lord Howe and Norfolk Islands in the South Australian Museum. Transactions and Proceedings of the Royal Society of South Australia 41: 5356.

Turner, A.J., 1918. Further notes on some moths from Lord Howe and Norfolk Islands in the South Australian Museum. Transactions and Proceedings of the Royal Society of South Australia 42: 276-289.

Turner, J.S., C.N. Smithers \& R.D. Hoogland, 1968. The Conservation of Norfolk Island. Australian Conservation Foundation Special Publication No. 1. 41 pp., 14 figs, 1 map.

Walker, J.J., 1886. Anosia plexippus L. (Danaus archippus F.) a study in geographical distribution. Entomologist's monthly Magazine 22: 217-224.

Waterhouse, G.A.H., \& G. Lyell, 1914. The Butterflies of Australia. A monograph of the Australian Rhopalocera. i-vi, 239 pp., 43 pls., map. Angus and Robertson. Sydney.

Watson, J.A.L., 1989. Termites (Isoptera) on Lord Howe Island. Report No. 89/1. 12 pp., 6 figs., Termite Group Report. Division of Entomology, CSIRO, Canberra.

Watson, J.A.L., G. Theischinger \& H.M. Abbey, 1991. The Australian Dragonflies. i-vii, 278 pp. CSIRO. Canberra.

Westwood, J.O., 1842. Descriptions of some new species of Cetoniidae from Australia, Asia and the Asiatic Islands. Arcana Entomologica 1(7): 103-104, pl. XXVIII. 
Wheeler, W.M., 1927a. Ants of the genus Amblypone Erichson. Proceedings of the American Academy of Science 62: 1-29, 8 figs.

Wheeler, W.M., 1927b. The ants of Lord Howe Island and Norfolk Island. Proceedings of the American Academy of Science 62(4): 121-153, 12 figs.

Wheeler, W.M., 1935. Checklist of the ants of Oceania. Occasional Papers of the B.P. Bishop Museum 11(11): 1-56.

Winstanley, W.J., 1983. Notes on Hemicordulia australiae (Odonata: Corduliidae) from the New Zealand Region. New Zealand Entomologist 7(4): 457-460.

Winstanley, W.J., \& R.L. Brock, 1983. Some Odonata from Norfolk Island. New Zealand Entomologist 7(4): 455-457, figs. $1 \mathrm{~A}-1 \mathrm{C}$.

Wise, K.A.J., 1963. A list of the Neuroptera of New Zealand. Pacific Insects 5(1): 53-58.

Wise, K.A.J., 1969. Three new insect records for the Auckland area, New Zealand. Records of the Auckland Institute and Museum 6(46): 423-426, 3 figs.

Wise, K.A.J., 1973. New records in the New Zealand Neuroptera: Hemerobiidae. New Zealand Entomologist 5(2): 181-185, 5 figs.

Wise, K.A.J., 1980. Records of South Pacific dragonflies (Hexapoda: Odonata). Records of the Auckland Institute and Museum 17: 175-178.

Wise. K.A.J., 1991. Distribution and zoogeography of New Zealand Megaloptera and Neuroptera. Records of the Auckland Institute and Museum 28: 211-227, 8 figs.

Wygodzinsky, P., 1956. Synopsis of the Australian Emesinae (Hemiptera: Reduviidae). University of California Publications in Entomology 11: 193-245.

Zeck, E.H., 1930. Notes on the identification of certain Noctuid pupae. Australian Naturalist 8(2): 32, 33, 5 figs.

Zimmerman, E.C., 1991. Australian Weevils. Colour plates. Vol. V. i-ix. Colour plates 1-304, 633 pp. CSIRO. Australia. Entomological Society of America.

Zimmerman, E.C., 1992. Australian Weevils. Colour plates. Vol. VI. i-vii. Colour plates 305-632, 707 pp. CSIRO. Australia. Entomological Society of America.

Zimmerman, E.C., 1993. Australian Weevils. Nanophyidae, Rhynchophoridae, Erirhinidae, Curculionidae: Amycterinae, Literature consulted. Vol. III. i-x, 854 pp. CSIRO. Australia. Entomological Society of America.

Zimmerman, E.C., 1994a. Australian Weevils. Anthribidae to Attelabidae. Vol. I. i-xxxii, 741 pp. CSIRO, Australia. Entomological Society of America. CSIRO.

Zimmerman, E.C., 1994b. Australian Weevils. Brentidae, Eurhynchidae, Apionidae and a chapter on the immature stages by Brenda May. Vol. II. i-x, 755 pp. CSIRO. Australia. Entomological Society of America.

Zuska, J., 1989. Sepsidae. In: N.L. Evenhuis (ed.). Catalog of the Diptera of the Australasian and Oceanian Regions. Bishop Museum Special Publication 86: 572-574.

Manuscript received 1 October 1996; accepted 10 March 1997.
ACKNOWLEDGMENTS. I have received considerable help from many people in connection with work on the Norfolk Island species list and I thank them all for their help. In particular, the librarians of the Australian Museum have always been most tolerant and helpful in handling my enquiries. Max Moulds has readily shared his knowledge of Australian entomological literature and provided references from his personal library. Dan Bickel, Gerry Cassis, Clarry Chadwick, Alan Dyce, Ted Edwards, Murray Fletcher, David McAlpine, Barry Moore, John Peters, Chris Reid, Richard Russell and Bob Taylor have all helped with information in their special fields. Owen and Beryl Evans, always ready to share their remarkable knowledge of the island's natural history, have, since my first visit to the island in 1967 , helped in many ways.

\section{Addendum}

After this paper had reached proof stage a set of the journals of the Norfolk Island Flora and Fauna Society, Norfolk Nature Notes, was kindly provided by Mrs Angela Guymer. This provided several references which had been missed. These are listed here in chronological order. Apart from Evans (1989), which mentions a mantid found on the island, they do not provide confirmed additions to the species list.

Christian, M., 1984. Wanderer butterfly (Danaus plexippus). Cicada. 2(1): 101-102.

Anonymous, 1986. Wanderer butterfly. 2(2): 109.

Endersby, I., 1986. Norfolk Island dragonflies. 2(2): 110-111. (Lists known species. Further species mentioned, identity not supported by specimens).

Hicks, J., 1986. Army worms on Philip Island. 2(2): 112.

Edwards, E.D., 1986. Management aspects mentioned in the Invertebrate Survey on Philip Island, 1984. 2(6): 136-137. (Lepidoptera, Psocoptera, Hymenoptera, Blattodea and Coleoptera). (Summary of part of a CSIRO Report of which I have not seen the original).

Anonymous, 1986. The crickets of Lord Howe Island and Norfolk Island. 1(7): 142-144. (Partial summary of contents of Otte \& Rentz, 1985).

Anonymous, 1986. Another correction. 2(8): 147. (Refers to an omission from an earlier note which refers to one by B. Evans. (Danaus plexippus, Vanessa itea, Danaus chrysippus).

William, J., 1988. You should have all come. 4(7): 279.

Anonymous, 1989. Once in a Blue Moon. 5(3): 303. (Hypolimnas bolina).

Evans, B., 1989. Praying mantis. 5(3): 306. (Records Notomantis brunneriana, the first record of a mantid from Norfolk Island).

Endersby, I., 1995. A new dragonfly for Norfolk Island. 11(2): 388-389. (Lists known species. An additional species reported, identity uncertain, not supported by specimens). 
Acontiinae ........................................... 40

Acrididae ……........................................ 6

Acridinae ................................................ 6

Acridoidea ............................................ 6

Acronictinae ....................................... 40

Adephaga .............................................. 14

Aderidae ............................................... 19

Aeshnidae .............................................. 3

Aeshninae ............................................... 3

Aeshnoidea ........................................... 3

Agriocnemidinae .................................. 3

Agromyzidae ...................................... 24

Agromyzinae .......................................24

Agrypninae .......................................... 17

Aleocharinae ...................................... 15

Amblycera ........................................ 8

Amphigerontiinae …............................. 8

Anacampsinae ..................................... 29

Anisolabididae …..................................... 4

Anisolabidinae ........................................ 4

Anisolabidoidea ...................................... 4

Anisoptera …............................................ 3

Anobiidae .............................................. 18

Anthicidae ............................................. 19

Anthocoridae ........................................ 11

Anthocorinae ....................................... 11

Anthomyiidae ....................................225

Anthribidae ........................................... 21

Anthribinae ........................................ 21

Aphididae ............................................ 9

Aphidinae ........................................... 9

Aphidoidea …....................................... 9

Aphilinidae .......................................... 44

Aphodiinae ......................................... 16

Apidae ............................................... 46

Apinae .................................................... 46

Apochrysinae …………………............ 13

Apocrita ................................................ 42

Apoidea ............................................... 46

Aradidae .............................................. 11

Aradoidea ................................................ 11

Arctiidae .............................................. 38

Arctiinae ............................................ 38

Arthropleona ........................................... 3

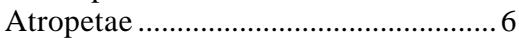

Auchenorrhyncha ................................ 10

Bedelliinae .........................................28

Bethylidae ........................................... 44

Bethylinae .......................................... 44

Bibionomorpha ................................... 23

Blaberidae .............................................. 4

Blaberoidea .............................................. 4

Blastobasidae …………………........... 28

Blattellidae ............................................. 4

Blattellinae ............................................ 4

Blattidae ............................................... 4

Blattinae ............................................... 4

Blattodea ......................................... 4, 52

Blattoidea ............................................ 4

Bostrichidae ........................................ 17

Bostrichinae ……................................. 17

Bostrichoidea ...................................... 17

Brachmiinae ......................................... 29

Brachycera …........................................ 23

Braconidae ……………………........... 42

Brentidae ............................................... 21
Brentinae .............................................. 21

Buprestidae ........................................ 17

Buprestinae ........................................... 17

Buprestoidea ........................................ 17

Caeciliidae ............................................ 7

Caeciliinae ............................................. 7

Caecilioidea …....................................... 7

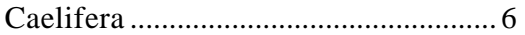

Calisiinae .............................................. 11

Calliphoridae ......................................26

Calliphorinae ........................................26 26

Callistinae ............................................ 14

Carabidae ............................................ 14

Carabinae ............................................ 15

Caraboidea ............................................ 14

Carposinidae ........................................ 30

Carventinae …......................................... 11

Catocalinae .......................................... 38

Cerambycidae ....................................... 19

Cerambycinae …….............................. 19

Ceraphronidae ..................................... 42

Ceraphronoidea ..................................... 42

Ceratopogonidae ................................... 23

Ceratopogoninae .................................. 23

Cetoniinae ............................................ 17

Chalcididae .......................................... 43

Chalcidinae ......................................... 43

Chalcidoidea ....................................... 43

Chelariinae ............................................ 28

Chironomoidea …................................. 23

Chlidanotinae ....................................... 29

Chloephorinae ....................................... 40

Choraginae ...........................................2 21

Chore utidae .......................................... 30

Choreutinae .......................................... 30

Chrysididae ............................................ 44

Chrysidinae ............................................ 44

Chrysidoidea ......................................... 44

Chrysomelidae .................................... 20

Chrysomeloidea .................................... 19

Chrysomyinae ....................................... 26

Chrysopidae ....................................... 13

Chrysopinae ........................................ 13

Cicadellidae ......................................... 10

Cicadelloidea ……….............................. 10

Cicadidae ............................................... 10

Cicadoidea ............................................ 10

Cimicoidea ............................................. 11

Cixiidae .................................................. 10

Cleonyminae ......................................... 43

Cleroidea .............................................. 18

Coccidae ................................................. 9

Coccinellidae …………….................. 18

Coccoidea ................................................

Coenagrionidae ..................................... 3

Coenagrionoidea …................................ 3

Coenosiinae ...........................................25

Coleoptera ..................................... 14, 52

Collembola .............................................. 3

Colletidae ……….................................... 46

Conocephalinae ..................................... 5

Copromorphoidea ................................ 30

Copromyzinae ....................................... 24

Corduliidae ............................................. 4

Corduliinae …………………………... 4

Corylophidae ........................................ 19
Cosmopterigidae ...................................28

Cosmopteriginae …................................ 28

Cossoninae .......................................... 21

Crambinae .............................................. 31

Cryptorhynchinae ……........................ 21

Cucujoidea ………………................... 18

Cuculiinae ............................................. 40

Culicidae .............................................. 22

Culicinae ............................................. 22

Culicoidea ......................................... 22

Culicomorpha ................................... 22

Curculionidae .......................................2 21

Curculionoidea ...................................... 20

Cyclorrhapha ........................................ 24

Cydnidae ............................................. 12

Cydninae ............................................ 12

Danainae .................................... 35, 52

Dasyheleinae ......................................... 23

Delphacidae .......................................... 10

Delphacinae ........................................... 10

Deltocephalinae .................................... 10

Denticollinae ......................................... 17

Dermaptera ................................................ 4

Diapriidae ............................................. 43

Dichromeridinae .................................. 29

Diparinae .......................................... 43

Diptera ................................................. 22

Dolichoderinae ......................................4 46

Dolichopodidae ..................................... 23

Dolichopodinae ..................................... 23

Drosophilidae .......................................... 24

Drosophilinae .......................................24

Dryinidae ............................................ 44

Dynastinae ............................................. 17

Echinopsocinae ....................................... 6

Ectopsocidae ........................................ 7

Elachistidae ...........................................28

Elachistinae ........................................ 28

Elateridae ................................................ 17

Elaterinae ............................................... 17

Elateroidea ........................................... 17

Elipsocidae .............................................. 7

Emesinae ............................................. 11

Empidoidea …..................................... 23

Encyrtidae ................................................ 43

Encyrtinae ............................................ 43

Endotrichinae ........................................ 31

Eneopterinae .......................................... 6

Ennominae ............................................ 33

Ensifera ………….............................. 5

Epermeniidae ...................................... 31

Epermeniinae ….................................. 31

Epermenioidea ....................................... 31

Ephydroidea ....................................... 24

Epyrinae .............................................. 44

Erechthiinae ....................................... 27

Eucnemidae ........................................... 17

Eulophidae ............................................ 44

Eulophinae ………................................ 44

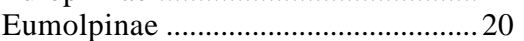

Eunotinae ............................................ 43

Evergestinae ........................................ 32

Fanniidae ........................................ 25

Fanniinae ........................................... 25

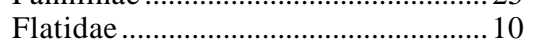

Forcipomyiinae ……………............... 23 
Forficulina ........................................ 4

Formicidae ............................................. 44

Formicinae ........................................ 46

Frieseinae .......................................... 3

Fulgoroidea ........................................ 10

Galerucinae .......................................20

Gasterophilidae ................................2 27

Gelechiidae .........................................28

Gelechiinae .........................................29

Gelechioidea .....................................28

Geometridae ..................................... 33

Geometrinae ….......................................33

Geometroidea ....................................... 33

Gerroidea ........................................... 11

Glaphyriinae ........................................ 32

Glossata ........................................2 27

Gracillariidae ........................................28

Gracillariinae .......................................28

Gryllidae ........................................... 5

Gryllinae …………............................. 5

Grylloidea ………................................ 5

Gyrinidae ……….................................. 15

Hadeninae ............................................... 41

Hapsiferinae .......................................28

Harpalinae ............................................... 14

Heliomyzoidea ....................................... 24

Heliothinae ............................................. 42

Hemerobiidae ......................................... 12

Hemerobioidea ................................... 12

Hemiptera .............................................. 9

Heteroptera .......................................... 10

Hieroxestinae ......................................2 27

Hispinae ............................................ 20

Histeridae ............................................ 15

Homilopsocidea ..................................... 7

Homoneurinae ……................................ 24

Hydrometridae ...................................... 10

Hydrometrinae ....................................... 10

Hydrometroidea ................................. 10

Hydrophilidae ...................................... 15

Hydrophiloidea ...................................... 15

Hydrophorinae ……………................... 23

Hylaeinae .............................................. 46

Hymenoptera ............................. 42, 52

Hypeninae ............................................ 38

Hypenodinae .......................................... 38

Hypogastruridae .................................... 3

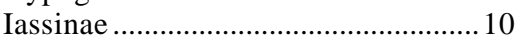

Ichneumonidae .................................. 42

Ichneumonoidea .................................. 42

Idolothripinae .................................... 12

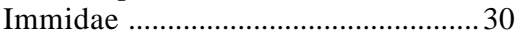

Immoidea …............................................ 30

Ischnocera ............................................. 8

Ischnurinae .......................................... 3

Isoptera .............................................. 4

Issidae ............................................. 10

Kalotermitidae ......................................... 4

Laemobothriidae …................................ 8

Laemophloeidae ................................. 18

Lamiinae ............................................. 20

Lampriminae ....................................... 16

Larentiinae ........................................... 34

Larrinae ...............................................4 46

Lauxaniidae ………………………............ 24

Lauxaniinae ........................................... 24
Lebiinae ................................................. 14

Lecithoceridae ...................................... 29

Lepidopsocidae ...................................... 6

Lepidoptera ............................... 27, 52

Lepolepidinae ........................................ 6

Leptoceridae ......................................... 27

Libelluloidea ............................................. 4

Licininae ........................................... 14

Limnephiloidea ................................... 27

Limoniinae ........................................... 22

Limosininae ........................................... 24

Listroscelidinae ...................................... 5

Lithocolletinae .................................... 28

Lithosiinae ............................................ 38

Lucanidae ............................................. 16

Ludiinae ............................................. 17

Lycaenidae .......................................... 37

Lygaeidae ............................................... 12

Lygaeoidea ........................................... 12

Lyonetiidae ..........................................28

Macroglossinae .................................... 37

Margarodidae ......................................... 9

Menoponidae ......................................... 8

Microveliinae …..................................... 11

Miridae .................................................. 11

Mirinae ............................................... 11

Miroidea …............................................ 11

Mogoplistinae ......................................... 6

Momphidae ......................................... 28

Mordellidae .......................................... 19

Muscidae .............................................22

Muscinae …..........................................25

Muscoidea ……………………........... 25

Myopsocidae ........................................ 8

Myrmeleontidae ................................. 14

Myrmeleontinae .................................... 14

Myrmeleontoidea ................................. 14

Myrmicinae ........................................... 45

Nabidae ............................................... 11

Nabinae ................................................ 11

Neanuridae ................................................ 3

Neanurinae ............................................. 3

Nematocera ..........................................22

Nemobiinae ............................................ 5

Neuroptera ............................................ 12

Nicoletiidae .............................................. 3

Nicoletiinae ........................................... 3

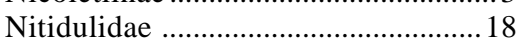

Noctuidae ............................................. 38

Noctuinae .............................................. 41

Noctuoidea .......................................... 38

Nolinae .................................................. 40

Nymphalidae .......................................... 35

Nymphalinae .............................. 36, 52

Nymphulinae ........................................ 31

Odonata ...................................... 3, 52

Oecophoridae …....................................28

Oecophorinae .........................................28 28

Olethreutinae ......................................29

Omaliinae ............................................ 16

Ophioninae ......................................... 42

Opomyzoidea ........................................ 24

Orsillinae ................................................ 12

Orthoptera …................................ 5, 52

Orthorrhapha ....................................... 23

Orthotylinae ......................................... 11
Paederinae ............................................. 16

Panesthiinae ........................................... 4

Papilionidae ........................................... 34

Papilioninae .......................................... 34

Papilionoidea ……................................. 34

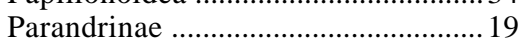

Pentatomidae ..................................... 12

Pentatominae ........................................ 12

Pentatomoidea ...................................... 12

Peripsocidae .......................................... 7

Phalangopsinae …………………........... 5

Phaneropterinae ………………............... 5

Phaoniinae .......................................... 26

Philopteridae ...................................... 8

Philotarsidae ..................................... 8

Philotarsinae ...................................... 8

Phlaeothripidae .................................... 12

Phlaeothripinae .................................... 12

Phthiraptera ........................................... 8

Phycitinae ............................................ 31

Phylinae .................................................... 11

Phytomyzinae ………............................24

Pieridae ................................................. 35

Pierinae ................................................. 35

Pimplinae ........................................... 42

Platygasteroidea .................................... 43

Platypodinae ………........................... 21

Platystomatidae ....................................24

Platystomatinae ....................................2 24

Plusiinae ................................................ 40

Plutellidae ............................................... 28

Plutellinae ............................................. 28

Poduroidea ............................................. 3

Polyommatinae .................................... 37

Polyphaga .............................................. 15

Polyzosteriinae ......................................... 4

Ponerinae .............................................. 44

Praydinae ......................................... 28

Prioninae ................................................ 19

Pristocerinae ......................................... 44

Proctotrupoidea ...................................... 43

Propsocinae ............................................... 7

Pseudocaeciliidae ................................. 7

Pseudocaeciliinae .................................. 7

Pseudococcidae ...................................... 9

Pseudomopinae ...................................... 4

Psocetae ................................................. 8

Psocidae ……......................................... 8

Psocomorpha .......................................... 7

Psocoptera .................................... 6, 52

Psydrinae ......................................... 15

Pteromalidae .......................................... 43

Pteromalinae ......................................... 43

Pterophoridae ……................................. 31

Pterophoroidea ....................................... 31

Pterostichinae ...................................... 15

Ptiliidae ............................................... 15

Pulicidae ........................................... 22

Pulicoidea ............................................ 22

Pycnoscelinae ..................................... 4

Pyralidae ................................................. 31

Pyraloidea …........................................ 31

Pyraustinae ........................................... 32

Pyrophorinae ......................................... 17

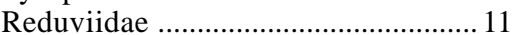

Reduvioidea ........................................... 11 
Rhaphiinae .......................................... 24

Rhyparochrominae ............................ 12

Rhytirhininae ...................................... 21

Ricaniidae ............................................ 10

Ricinidae ............................................ 8

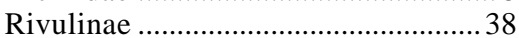

Sarcophagidae ...................................... 26

Sarcophaginae ..................................... 26

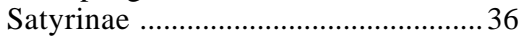

Scarabaeidae ..................................... 16

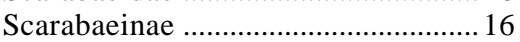

Scarabaeoidea .................................... 16

Scardiinae ............................................ 27

Scaritinae ............................................. 14

Scatopsidae …………………............. 23

Scatopsinae ....................................... 23

Scelionidae ......................................... 43

Scelioninae .............................................. 43

Schizophora ……….............................. 24

Sciapodinae …...................................... 23

Sciomyzoidea ....................................... 24

Scolebythidae ......................................4 44

Scolytinae …………........................... 21

Scopariinae ............................................ 31

Sepsidae …............................................ 24

Sepsinae .............................................. 24

Sericoderinae ....................................... 19

Sesioidea .................................................... 30

Setomorphinae .....................................2 27

Silvanidae ............................................ 18

Simuliidae ........................................... 23

Simuliinae ............................................. 23
Siphonaptera ....................................... 22

Sminthuridae ......................................... 3

Sphaeridiinae ........................................ 15

Sphaeroceridae .................................... 24

Sphecidae ............................................46

Sphecoidea ............................................4 46

Sphingidae …………………............... 37

Sphinginae ............................................. 37

Sphingoidea ………………………...... 37

Staphylinidae ..................................... 15

Staphylininae ........................................ 16

Staphylinoidea …................................ 15

Stathmopodinae .................................. 28

Steganinae ………................................ 25

Sternorrhyncha ................................... 9

Sterrhinae .............................................. 33

Symphypleona ….................................... 3

Syndesinae ............................................. 16

Teleasinae ................................................ 43

Tenebrionidae ....................................... 19

Tenebrionoidea ..................................... 19

Tephritoidea ......................................... 24

Terebrantia .............................................. 12

Tetracteminae ....................................... 43

Tettigoniidae ............................................ 5

Tettigonioidea …..................................... 5

Thripidae .............................................. 12

Thripinae ................................................ 12

Thysanoptera ........................................ 12

Thysanura ............................................... 3

Tibicininae .......................................... 10

Tineidae .................................................. 27
Tineinae ................................................ 27

Tineoidea .............................................. 27

Tingidae ................................................... 11

Tinginae ................................................. 11

Tingoidea ........................................... 11

Tiphiidae ............................................... 44

Tipulidae .................................................22

Tipulomorpha ....................................22

Tortricidae …………………..............29

Tortricinae ....................................... 29

Tortricoidea ........................................ 29

Trichoptera …........................................ 27

Trigonidiinae ............................................ 5

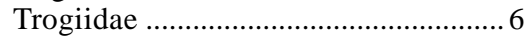

Trogiinae ............................................... 6

Trogiomorpha ...................................... 6

Trogossitidae ......................................... 18

Trogossitinae .......................................... 18

Tryphoninae ........................................ 42

Tubulifera ............................................... 12

Typhlocybinae ...................................... 10

Veliidae ................................................ 11

Vespidae ............................................ 44

Vespinae .................................................. 44

Vespoidea .............................................. 44

Xantholininae ……………………...... 16

Yponomeutidae ……............................28

Yponomeutinae ...................................2 28

Yponomeutoidea ...................................28

Zygoptera .............................................. 3 


\section{LEPIDODPTERA.}

EQUIT ES ACHIVT.

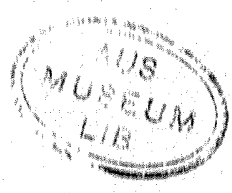

\section{PA P I I O ILIONEUS.}

\section{SPECIFIC CHARACTER.}

Wings tailed, black, band on the anterior pair, and difk of the pofterior, yellow: beneath, lunules yellow with fanguineous fpots.

Paprejo Ilioneus: alis caudatis nigris, anticis fafcia pofticisque difco flavis, fubtus lunulis flavis fanguineo-maculatis.

Our drawing of this fine nondefcript Butterfly is taken from a moft beautiful fpecimen in the cabinet of our worthy friend A. M'Leay, Efq. who received it with many others from New South Wales a hort time ago. We alfo have obtained a fpecimen of the fame fpecies from that country fince the drawing was taken.-This, with Papilio Ereetheus, and Egeus, may be numbered among the moft interefting entomological acquifitions hitherto introduced from South Wales to the acquaintance of European naturalists.

Front Cover Image AND ABove: Papilio ilioneus from E. Donovan's An Epitome of the Natural History of the Insects of New Holland, New Zealand, ..., published in London in 1805.

From the Rare Book Collection-Australian Museum Research Library. 